\title{
UnB
}

UNIVERSIDADE DE BRASÍLIA

CENTRO DE EXCELÊNCIAEM TURISMO

Programa de Pós-Graduação em Turismo

Mestrado Profissional

ELVIO SIQUIEROLI CAVATON

DESEJOS DO IMAGINÁRIO DE VIAGEM DOS JOVENS

DO PRONATEC NO DISTRITO FEDERAL 
ELVIO SIQUIEROLI CAVATON

\section{DESEJOS DO IMAGINÁRIO DE VIAGEM DOS JOVENS DO PRONATEC NO DISTRITO FEDERAL}

Dissertação apresentada ao Programa de Pós-Graduação em Turismo na Área de Concentração em Cultura e Desenvolvimento Regional na linha de pesquisa em Desenvolvimento, Políticas Públicas e Gestão de Turismo do Centro de Excelência em Turismo da Universidade de Brasília, como requisito parcial à obtenção do título de Mestre Profissional em Turismo.

Orientação: Prof. Dr. Neio Lucio de Oliveira Campos 
Ficha catalográfica elaborada automaticamente,

com os dados fornecidos pelo(a) autor(a)

CAVATON, ELVIO SIQUIEROLI
C377d
DESEJOS DO IMAGINÁRIO DE VIAGEM DOS JOVENS DO
PRONATEC NO DISTRITO FEDERAL / ELVIO SIQUIEROLI
CAVATON; orientador NEIO LUCIO DE OLIVEIRA CAMPOS.
- Brasilia, 2015.
$87 \mathrm{p}$.
Dissertação (Mestrado - Mestrado Profissional em
Turismo) - Universidade de Brasilia, 2015.
1. TURISMO. 2. IMAGINÁRIO. 3. DESEJOS DE VIAGEM.
I. CAMPOS, NEIO LUCIO DE OLIVEIRA, Orient. II.
Título.


CAVATON, Elvio Siquieroli. DESEJOS D O IMA GINÁRIO DE VIAGEM DOS JOVENS D O PRONATEC NO DISTRIT O FEDERAL. Dissertação apresentada ao Programa de PósGraduação em Turismo na Área de Concentração em Cultura e Desenvolvimento Regional na linha de pesquisa em Desenvolvimento, Políticas Públicas e Gestão de Turismo do Centro de Excelência em Turismo da Universidade de Brasília, como requisito parcial à obtenção do título de Mestre Profissional em Turismo.

Aprovado em 08 de julho de 2015.

BANCA EXAMINADORA

Prof. Dr. Neio Lucio de Oliveira Campos - Presidente

Centro de Excelência em Turismo/UnB

Profa. Dra. Cristina Maria Costa Leite - Membro

Faculdade de Educação/UnB

Profa. Dra. Maria Elenita Menezes Nascimento - Membro

Centro de Excelência em Turismo/UnB

Profa. Dra. Neuza de Farias Araújo - Suplente

Centro de Excelência em Turismo/UnB 
Aos meus filhos Thiago, Fábio e Caio 


\section{AGRADECIMENTOS}

Agradeço meu Orientador, Prof. Dr. Neio Campos, pela orientação e fornecimento de mapas e rotas que guiaram este navegante rumo a seu destino.

Agradeço aos meus pais, Fábio e Mafalda, a educação que me proporcionaram.

Agradeço a Fernanda, esposa amada, o incentivo e o suporte nessa jornada.

Agradeço à diretoria do Instituto Federal de Brasília - IFB e, em especial, à coordenação do Programa Nacional de Acesso ao Ensino Técnico e Emprego - PRONATEC, pela colaboração recebida durante a realização deste trabalho.

Agradeço os jovens estudantes do PRONATEC pela gentil concessão das entrevistas.

Agradeço a colaboração de todas e de todos com quem convivi no Centro de Excelência em Turismo da Universidade de Brasília.

Este trabalho contém um pouco de cada um de vocês. 
Quem quer que feche os olhos sobre o que é e vê apenas o que deveria ser aprende antes a se perder do que a se conservar.

Maquiavel 


\section{RESUM 0}

A problemática abordada neste trabalho diz respeito a ampliar o acesso dos jovens de baixa renda à educação e ao lazer, mediante a prática do turismo. O objetivo foi explorar o imaginário coletivo desses jovens para descrever desejos que sejam capazes de motivá-los a participar de uma viagem de turismo. Essa exploração fundamentou-se nas teorias sobre imagem e imaginário de Vigotsky, Sartre, Durand e Laplantine e Trindade e assumiu o pressuposto de que o imaginário é refratário a métodos quantitativos. Uma entrevista qualitativa com seis jovens foi levada a efeito, estimulando uma narrativa imaginada sobre a viagem de turismo e, assim, descreveu-se 18 desejos relativos a essa viagem, a saber: desejo de mordomia, conforto, descanso, tempo livre, diversão, redução de controles sociais, contemplar paisagens, integração com a natureza, aventura, consumo, viajar em grupo, interação social face a face, contemplar objetos extraordinários, alargar horizontes, comparar os modos de vida, autenticidade, desenvolvimento intelectual e mudança de status. Análise levou em conta os conceitos de Turismo e Turismo Social e revelou que todos os desejos descritos são passíveis de satisfação no âmbito de uma viagem turística e que apresentam algum tipo de relação com a educação ou o lazer. Concluiu-se pela possibilidade de os desejos descritos serem satisfeitos no âmbito de uma viagem de turismo; pela competência do Turismo para ser uma via de acesso à educação e ao lazer; e pela necessidade de implementação de uma política pública voltada para reduzir o déficit educacional e de lazer a que estão submetidos os jovens de baixa renda, por não terem acesso às viagens de turismo.

Palavras-chave: Imaginário. Turismo. Desejo. Jovem. Viagem. Turismo Social. 


\begin{abstract}
The problem addressed in this study relates to expanding the access of low-income youth to education and leisure, through the avenue of tourism. The objective was to explore the collective imaginary of these youth to describe desires, while being able to motivate them to participate in a tourist trip, they interact with education and leisure and can be satisfied during a tourist trip. This exploration was based on the theories of image and imaginary by Vygotsky, Sartre, Durand and Laplantine and Trindade and considered the assumption that the imaginary is refractory to quantitative methods. A qualitative interview with six youths was carried out by stimulating an imagined narrative of the tourist trip and thus 18 wishes regarding this trip were described, namely desire for stewardship, comfort, rest, free time, fun, reduction of social controls, to contemplate landscapes, interaction with nature, adventure, consumption, travel in group, face to face social interaction, to contemplate extraordinary objects, broaden horizons, to compare ways of life, authenticity, intellectual development and status change. The analysis took into consideration the concepts of Tourism and Social Tourism and revealed that every desires described are subject to satisfaction within a tourist trip and have some kind of relationship with education or leisure. It was concluded that the possibility exists of satisfying the described desires within a tourist trip; the competence of Tourism to be a route of access to education and leisure; and the need to implement a public policy to reduce the deficit of education and leisure that low-income youth are submitted due to their lack of access to tourist trips.
\end{abstract}

Keywords: Imaginary. Tourism. Desire. Young. Trip. Social Tourism. 


\section{LISTA DE FIGURAS}

Figura 1 - O Cavaleiro, a Morte e o Diabo, de Dürer 25

Figura 2 - Elementos da imagem $\quad 28$

Figura 3 - Elementos do imaginário $\quad 29$

Figura 4 - Relações entre desejos, imaginário e viagem de turismo 42 


\section{LISTA DE GRÁFICOS}

Gráfico 1: Porque você realizou uma viagem durante suas férias regulamentares? 40

Gráfico 2: Variação das motivações para as viagens ao exterior a partir do Reino Unido 
Tabela 1 - Exemplos da relação entre necessidade, desejo e produto 41

Tabela 2 -Critérios de definição das características dos participantes 55

Tabela 3-Características dos participantes $\quad 56$

Tabela 4 -Caracterização dos desejos $\quad 61$

Tabela 5 - Categorização dos desejos do grupo $1 \quad 62$

Tabela 6 - Categorização dos desejos do grupo $2 \quad 62$

Tabela 7 -Categorização dos desejos do grupo $3 \quad 63$

Tabela 8 -Categorização dos desejos do grupo 4

Tabela 9 - Categorização dos desejos do grupo $5 \quad 64$

Tabela 10 - Categorização dos desejos do grupo $6 \quad 64$

Tabela 11 - Categorização dos desejos do grupo $7 \quad 65$

Tabela 12 - Categorização dos desejos do grupo $8 \quad 65$

Tabela 13 - Categorização dos desejos do grupo 9

Tabela 14 - Categorização dos desejos do grupo $10 \quad 67$

Tabela 15 - Categorização dos desejos do grupo $11 \quad 67$

Tabela 16 - Categorização dos desejos do grupo $12 \quad 68$

Tabela 17 - Categorização dos desejos do grupo $13 \quad 68$

Tabela 18 - Categorização dos desejos do grupo $14 \quad 69$

Tabela 19 - Categorização dos desejos do grupo 15

Tabela 20 - Categorização dos desejos do grupo $16 \quad 70$

Tabela 21 - Categorização dos desejos do grupo $17 \quad 71$

Tabela 22 - Categorização dos desejos do grupo $18 \quad 71$ 
SUMÁRIO

INTRODUÇÃO 14

1. IMAGINÁRIO E IMAGEM 22

1.1 IMAGINÁRIO E JUVENTUDE 30

2. IMAGINÁRIO, VIAGEM DE TURISMO E POLÍTICAS PÚBLICAS 38

2.1 IMAGINÁRIO E MOTIVAÇÃO PARA VIAJAR 39

2.2 POLÍTICAS PÚBLICAS E TURISMO SOCIAL 45

2.2.1 Políticas públicas voltadas para Turismo Social na Europa e no Brasil 48

2.2.2 Os benefícios do Turismo Social 49

2.3 TURISMO SOCIAL E JOVENS DE BAIXA RENDA 50

3. DESEJOS DO IMAGINÁRIO DE VIAGEM DOS JOVENS DO PRONATEC NO DISTRITO FEDERAL - PROCEDIMENTOS METODOLÓGICOS 53

4. DESCRIÇÃO E ANÁLISE DOS DESEJOS DE UMA VIAGEM IMAGINADA 60 CONSIDERAÇÕES FINAIS

REFERÊNCIAS 75

APÊNDICE A - ESTIMATIVA DO NÚMERO DE JOVENS QUE NÃO VIAJARAM EM 2013 POR FALTA DE DINHEIRO 82

APÊNDICE B - PROTOCOLO DA ENTREVISTA QUALITATIVA 84

APÊNDICE C - TERMO DE CONSENTIMENTO LIVRE E ESCLARECIDO 87 


\section{INTRODUÇÃO}

Os direitos humanos ao lazer, à educação, a participar da vida cultural da comunidade e a fruir as artes foram declarados, entre outros direitos humanos, em 1948, pela Assembleia Geral das Nações Unidas, mediante a Declaração Universal dos Direitos Humanos (ONU, 1948).

Essa declaração implicou o reconhecimento de que esses direitos decorrem da própria natureza humana e, portanto, eles preexistem a qualquer ordenamento jurídico nacional. Todavia, apesar de ser uma manifestação de ordem jurídica universal, o caráter unicamente declaratório da Declaração Universal dos Direitos Humanos não garante a nenhum cidadão do mundo o gozo desses direitos, porque para tornar efetivo qualquer direito em determinado território nacional é necessário que ele seja devidamente constituído (MARTINS FILHO, 1999).

Em nosso país, a Constituição Federal, promulgada em 1988, de caráter eminentemente constitutivo, albergou os direitos a que nos referimos acima. Em seu art. $6^{\circ}$, estabeleceu a educação e o lazer como direitos sociais, em seu art. 23 estabeleceu como competência comum da União, Estados, Distrito Federal e Municípios proporcionar os meios de acesso à cultura, à educação e à ciência, bem como fixou, em seu art. 215, que o Estado garantirá a todos o acesso às fontes da cultura nacional (BRASIL, 1988).

Nossa Constituição foi mais longe quando tratou de garantir esses direitos aos jovens. No art. 227, dispôs que é dever da família, da sociedade e do Estado assegurar à criança, ao adolescente e ao jovem, com absoluta prioridade, juntamente com outros direitos ali citados, o direito ao lazer, à educação e à cultura (BRASIL, 1988).

Esses direitos, assim como os direitos à saúde, à segurança, à previdência social pertencem ao grupo dos chamados direitos positivos, isto é, daqueles que demandam uma ação do Estado para se efetivarem (MARTINS FILHO, 1999). Assim, cabe ao Estado formular e implementar políticas públicas com vistas a promover o acesso dos cidadãos ao lazer, à educação e à cultura, bem como aos demais direitos positivos. Nossa Carta Magna também estabelece, em seu art. 180, que todas as esferas de poder público promoverão e incentivarão o Turismo como fator de desenvolvimento social e econômico. 
O Turismo tem um papel proeminente a desempenhar nas políticas públicas destinadas a promover o acesso ao lazer, à educação, à cultura e à arte, porque sua prática é uma eficaz via de acesso à fruição desses bens. Em relação ao lazer, esse papel é mais evidente, uma vez que o turismo tem, reconhecidamente, o lazer como uma de suas principais finalidades.

Quanto à educação, seu papel tem sido cada vez mais reconhecido. É notório que, desde a educação infantil, passando pelo ensino fundamental, médio e universitário, até os programas de pós-graduação encontramos atividades que vinculam educação e turismo. São as atividades extraclasse, excursões, programas de intercâmbio, pesquisas de campo, bolsas de estudo que contemplam atividades fora da cidade ou do país sede da instituição de ensino, bem como outras modalidades de ensino e pesquisa que contemplam deslocamentos do aluno.

Assim, a educação não precisa ser ministrada somente no espaço da sala de aula. É prática corrente na pedagogia de muitas escolas efetuar deslocamentos dos alunos para fora de seus muros, para que aprendam entrando em contato com outras realidades. A esse respeito, o mestre brasileiro Paulo Freire ensina que a educação para todos, libertadora, é importante na escola como também fora dela. "A educação ligada aos direitos humanos [...] tem que ser abrangente, totalizante; ela tem que ver com o conhecimento crítico do real e com a alegria de viver" (FREIRE; FREIRE, 2001, 102). Assim, podemos relacionar educação e turismo a partir do conhecimento crítico do real e da alegria de viver.

$\mathrm{Na}$ educação formal, encontramos uma interface do turismo com a educação no chamado turismo educativo ou pedagógico (OLIVEIRA, 2006; PERINOTTO, 2008). Nessa interface, a viagem de turismo viabiliza práticas pedagógicas em que vários conteúdos das disciplinas do currículo, tais como, geografia, biologia, história, educação física, entre outras, são experienciados em espaços fora da escola tais como o campo, sítios arqueológicos, cidades históricas, ecossistemas, até mesmo em uma simples ida ao Zoológico na mesma cidade. As atividades de ensino contidas nesses projetos interdisciplinares realizam saídas de campo, aulas passeio (FREINET, 1979) e visitações a lugares turísticos, ecológicos, históricos e do patrimônio cultural. Além disso, há a ligação das atividades pedagógicas fora dos muros da escola com o lazer (MORENO; SILVA, 2008).

Oficialmente, a valorização da experiência extraescolar está definida nas Diretrizes Curriculares Nacionais Gerais para a Educação Básica em seu art. 9º trata da escola de qualidade social centrada no aluno e na aprendizagem, e coloca como quesito a ser atendido a 
"revisão das referências conceituais quanto aos diferentes espaços e tempos educativos, abrangendo espaços sociais na escola e fora dela" (BRASIL, 2010b, p. 3).

Em outra interface entre educação e turismo, as práticas pedagógicas podem dar suporte conceitual e prático para a formação do turista, na medida que a viagem turística pode ser colhida como uma oportunidade adequada para transmitir aos viajantes princípios éticos voltados para a sustentabilidade e a responsabilidade, para o respeito a outras culturas e ao meio ambiente, formando turistas que preservem e conservem a natureza e os monumentos históricos e respeitem as pessoas dos lugares que visitam (CAMARGO, 2005).

Encontramos outra interface entre educação e turismo nos ensinos técnico e superior em Turismo (SALGADO; MARTINS, 2007; VELASQUEZ, 2009) em cursos profissionalizantes em Turismo (COSTA; PAIVA; FILGUEIRA, 2006), e em educação patrimonial (FARIA, 2008), onde se busca educar para a prestação de serviços voltados à atividade turística, e pessoas são formadas para trabalhar em gastronomia, lazer, deslocamentos e demais atividades constituintes do fenômeno turístico. Há também o que alguns chamam de educação turística, onde a educação é utilizada como uma ferramenta para promoção e desenvolvimento do Turismo (CAMARGO, 2005; SOUZA, 2008).

Além da educação formal, podemos falar da educação não formal em que se prepara a população de uma região turística para receber turistas, e para preservar a cultura local e o meio ambiente (CARREIRO, 2003; CINTRA, 2010; KLEIN et al., 2011, PAIVA, 2004; SATO, 2007; SILVA, 2006; TAHARA; DIAS; SCHWARTZ, 2006).

Com referência à cultura, na segmentação de atividades turísticas, encontra-se o Turismo Cultural que, conforme o entendimento do Grupo Técnico Temático de Turismo Cultural da Câmara Temática de Segmentação do Conselho Nacional de Turismo, "compreende as atividades turísticas relacionadas à vivência do conjunto de elementos significativos do patrimônio histórico e cultural e dos eventos culturais, valorizando e promovendo os bens materiais e imateriais da cultura" (BRASIL, 2008b, p. 16).

Fica, portanto, claro que o Turismo é um meio eficaz para viabilizar o acesso dos cidadãos ao lazer, à educação e à cultura, desde que seja conduzido e praticado com esse objetivo. Entretanto, infelizmente, podemos verificar que essa eficaz via de acesso ao lazer, à educação e à cultura ainda não está disponível para todos. Um grande número de pessoas, apesar de desejar, deixa de realizar uma viagem turística porque não reúne as condições necessárias para 
os deslocamentos e as estadas inerentes a essa atividade, algumas por não disporem dos recursos financeiros, outras por dificuldades de locomoção, por deficiências físicas ou mentais, pela idade avançada ou por outras razões.

A existência de tais obstáculos à prática do turismo exige a formulação de políticas públicas destinadas a universalizar o acesso às viagens turísticas, eliminando as barreiras que se interpõem entre as pessoas que desejam praticar o turismo e a realização da viagem turística. A formulação dessas políticas, como já foi dito, é papel do Estado, mas precisa contar com a participação da sociedade e incorporar suas demandas por direitos iguais e por extensão da cidadania. Os alvos dessas políticas devem ser vistos como cidadãos com direito a ter direitos e não como cidadãos incapazes (DAGNINO, 2004).

No entanto, para incorporar as demandas sociais ao processo de elaboração de políticas públicas é necessário, antes, conhecê-las, e o sentido deste trabalho é avançar nesse conhecimento.

As características deste trabalho não permitem que estudemos as demandas de todos os grupos sociais que necessitam de políticas públicas específicas para viabilizar sua participação em viagens turísticas. Desse modo, optamos por focar nosso esforço nas pessoas que deixam de realizar viagens turísticas devido à insuficiência de recursos financeiros, mais especificamente nos jovens de baixa renda. São três as principais razões que orientam essa opção.

A primeira é o crescente interesse da sociedade brasileira em desenvolver políticas específicas para a juventude, cristalizado na edição da Lei $n^{\circ} 12.852$, de agosto de 2013, que "institui o Estatuto da Juventude e dispõe sobre os direitos dos jovens, os princípios e diretrizes das políticas públicas de juventude e o Sistema Nacional de Juventude - SINAJUVE” (BRASIL, 2013a). Esta lei estabelece princípios a serem aplicados nas políticas públicas de juventude, entre eles, o reconhecimento do jovem como sujeito de direitos universais, portanto sujeito dos direitos à educação, ao lazer e à fruição da cultura e das artes. Ela também estabelece diretrizes para os agentes públicos e privados envolvidos com políticas públicas de juventude, entre as quais destacamos: incentivar a ampla participação juvenil na formulação, implementação e avaliação de políticas públicas; garantir meios e equipamentos públicos que promovam o acesso à produção cultural, à prática esportiva, à mobilidade territorial e à fruição do tempo livre; promover o território como espaço de integração; promover a integração internacional entre os jovens, preferencialmente no âmbito da América Latina e da África, e a cooperação internacional. 
A segunda razão é a existência de elevado número de jovens brasileiros que não realizam viagens turísticas por falta de dinheiro, conforme demonstra pesquisa direcionada para caracterizar e dimensionar o turismo doméstico no Brasil, elaborada e aplicada pela Fundação Instituto de Pesquisas Econômicas - FIPE, que indicou, haver, em 2011, um elevado percentual de pessoas com renda domiciliar entre zero e quatro salários mínimos que não viajaram naquele ano, por não disporem dos recursos financeiros necessários. Também indicou, como era de se esperar, que a declaração de falta de dinheiro como principal motivo para não viajar é tão mais frequente quanto menor é a renda domiciliar. Assim, a faixa de renda domiciliar mensal situada entre 0 e 4 salários mínimos foi a que mais se absteve de viajar. Em 60, 8\% desses domicílios sequer uma pessoa viajou durante o ano e, em 53,7\% desses casos o principal motivo para não ter viajado foi a falta de dinheiro para viajar (BRASIL 2012a).

Assim, aplicando o resultado dessa pesquisa, realizada em 2011, aos dados e projeções divulgadas pelo IBGE (BRASIL, 2013c; 2014) para o ano de 2013, podemos estimar que aproximadamente nove milhões de jovens, entre 15 e 29 anos teriam deixado de viajar por falta de dinheiro, em $2013^{1}$.

Some-se a isso o fato que a grande maioria dos jovens de baixa renda frequentam escolas públicas que, por falta de recursos financeiros, mantém seu alunado intramuros, enquanto o alunado das escolas particulares, financiado pelos pais, se beneficia de práticas pedagógicas relacionadas ao turismo, tais como viagens a parques nacionais, cidades históricas e a todo tipo de lazer. O prejuízo dessa desigualdade se materializa na desarticulação na produção de conhecimento, devido à falta de diálogo entre as disciplinas do currículo dos vários cursos. Além disso, os alunos da camada social de baixa renda ficam de fora do prazer que uma viagem turística pode proporcionar, bem como da possibilidade de confrontar sua realidade pessoal e cultural com as de outras pessoas, em novas situações e novos lugares.

As atividades extraclasse que integram Turismo e Educação possibilitam aos jovens, entre outras coisas, observar e conhecer in loco a arte, o espaço, o ecossistema, os fazeres e os saberes das pessoas, que estudaram nos livros em sala de aula.

A visão fragmentada de conteúdos escolares e científicos desarticulada das práticas cotidianas, novidades e conflitos reais, é fugaz e sem significados duradouros para o aluno. A educação do

\footnotetext{
${ }^{1}$ Estimativa do número de jovens que não viajaram em 2013 por falta de dinheiro no APÊNDICE A.
} 
futuro requer saberes articulados numa perspectiva multidisciplinar e planetária (MORIN, 2004).

A terceira razão é que o governo brasileiro, por intermédio do Ministério do Turismo, já vem desenvolvendo políticas públicas concebidas para universalizar o acesso ao turismo mediante a eliminação de barreiras à sua prática. Tais como: Turismo Acessível (BRASIL, [201-]), Viaja Mais Melhor Idade (BRASIL, 2007), Férias do Trabalhador Brasileiro (BRASIL, 2010c), Viaja Mais Jovem (BRASIL, 2009). Note-se que esses programas podem ser classificados como de Turismo Social, porque envolvem subsídios financeiros à atividade turística, seja por parte do setor público ou do setor privado.

Com relação à participação dos jovens na elaboração de políticas públicas relativas ao Turismo, podemos dizer que embora o governo federal, nas últimas décadas, tenha incorporado várias formas de participação social no processo de formulação de políticas públicas, abrangendo conselhos, conferências, comissões, consultas e audiências públicas (BRASIL, 2010d), no âmbito do Ministério do Turismo não identificamos nenhuma forma de participação dos jovens na elaboração de políticas, sequer naquelas a eles destinadas. Tampouco consta na composição do Conselho Nacional de Turismo algum representante desse segmento social.

A nosso ver, é imprescindível que o processo de elaboração de uma política pública leve em conta as demandas e os anseios da população para, na medida do possível, atendê-los. Assim, consideramos que o levantamento e a análise do imaginário dos jovens de baixa renda sobre a viagem turística podem oferecer subsídios relevantes ao processo de elaboração de uma política de facilitação de acesso ao turismo. Porque, mediante esse estudo, será possível encontrar os desejos desses jovens em relação a essas viagens e subsidiar a elaboração de uma política que os integre de modo adequado à prática do turismo. Além disso, levar em conta o imaginário desse segmento social no processo de formulação da política é promover sua participação, ainda que de modo indireto, nesse processo. Em suma, descobrir os desejos dos jovens em relação à viagem de turismo possibilitará a elaboração de um produto, uma viagem turística, com características capazes de deflagrar sua motivação e consequente adesão à política.

Tendo esse contexto como pano de fundo, nossa proposta é obter dados que precisam ser levados em conta no processo de formulação de políticas públicas destinadas a universalizar a prática do Turismo e, assim, ampliar o acesso à educação, à cultura e ao lazer. 
Nossa escolha pelo levantamento do imaginário para encontrar desejos dos jovens em relação à viagem turística está ligada a três razões. A primeira é que, de acordo com Sartre (1996), a imagem que formamos de um objeto é uma síntese das percepções, saberes, afetividade e desejos que já possuímos em relação a ele. Assim, o estudo das imagens de uma viagem turística imaginária nos permitirá levantar os desejos que esses jovens possuem sobre ela e, com esse conhecimento, subsidiar a formação de viagens de turismo que atendam às expectativas dos alvos da política pública, no caso os jovens de baixa renda, pois "produtos turísticos podem ser 'fabricados' a partir de combinações de diferentes insumos disponíveis no mercado, como serviços de transportes, alojamento, entretenimento etc.” (TOMELIN, 2012, p. 401).

A segunda razão é que uma viagem turística é vinculada às imagens desde seu planejamento, desde quando ainda é uma imagem vaga, criada a partir da publicidade, da educação, das informações obtidas em reportagens, redes sociais; passando pela experiência da viagem, que elimina os elementos da imagem que não se confirmam e reforça aqueles que são considerados corretos; e terminando na etapa pós-imagem que pode induzir sentimentos de saudade, arrependimento, fantasias que implicarão uma nova sequência de imagens que influenciarão futuras decisões de viagem (GUNN ${ }^{2} 1972$ apud COOPER et al., 2007).

A terceira razão é que em pesquisa documental junto a órgãos governamentais, bem como em pesquisa bibliográfica, nota-se a ausência de conhecimento a respeito dos desejos dos jovens que não dispõem de dinheiro para viajar referentes a viagens turísticas. Podemos dizer que existe uma lacuna a preencher, o que justifica a eleição do presente objeto de pesquisa (DESLAURIERS; KÉRISIT, 2008).

Assim, a problemática desta pesquisa é oferecer subsídios à elaboração de políticas públicas direcionadas à prática do turismo por jovens de baixa renda, de modo a ampliar seu acesso à educação e ao lazer, respondendo à questão: quais dos seus desejos podem ser satisfeitos em uma viagem de turismo?

A partir dessa indagação, entrevistamos seis jovens participantes do Programa Nacional de Acesso ao Ensino Técnico e Emprego - PRONATEC, que atende prioritariamente jovens de baixa renda, e gravamos as entrevistas em áudio.

\footnotetext{
${ }^{2}$ GUNN, C. Vacationscape - Desining Tourist Regions, University of Texas Press, Austin, TX, 1972.
} 
Nosso objetivo geral é explorar o imaginário do jovem de baixa renda residente no Distrito Federal para descrever desejos que podem estimular sua motivação para participar de políticas públicas voltadas para a prática do turismo como via de acesso à educação e ao lazer.

Nossos objetivos específicos são:

1. Identificar jovens com o perfil requerido: homens e mulheres com idade entre 18 e 24 anos; solteiros; residentes no Distrito Federal, em domicílios com renda entre 0 e 4 salários mínimos e que não tenham realizado uma viagem de turismo nos últimos 3 anos.

2. Obter informações sobre o imaginário, a partir da descrição das várias dimensões de uma viagem de turismo hipotética e ideal.

3. Descrever os desejos indicados nessa viagem de turismo imaginária.

Este trabalho contém quatro capítulos. O primeiro traz algumas visões sobre o imaginário, sobre o processo de constituição de imagens e sobre seu papel na vida psíquica, e apresenta um histórico do imaginário de juventude, desde o final do século XIX até os dias de hoje, destacando o papel que o imaginário desempenha durante a juventude do indivíduo. O segundo capítulo envolve considerações sobre o imaginário de viagem e motivações de viagem, conceitos de turismo, de turista e uma análise sobre políticas públicas de Turismo Social no Brasil e na Europa. No terceiro, descrevemos os procedimentos metodológicos desenvolvidos na pesquisa. O quarto capítulo apresenta e discute os resultados da pesquisa. Em seguida, apresentamos nossas considerações finais. 


\section{IMAGINÁRIO E IMAGEM}

Esforços para decifrar as imagens e a imaginação vêm se desenvolvendo desde a cultura grega clássica até os dias de hoje. Ainda assim, quer seja acerca da imagem como resultado da percepção, da imagem relativa à lembrança, da imagem relativa ao sonho, ou da imagem mental que produzimos intencionalmente, ao que parece, esses esforços estão ainda longe de seu encerramento.

Para Aristóteles (2006 3 apud SAES, 2010), a imaginação é a capacidade de produzir imagens; é uma faculdade que se interpõe entre a percepção sensível e o intelecto. Ele afirma que sem percepção sensível não ocorre imaginação, assim como sem imaginação não ocorrem suposições e juízos, e que a imaginação desempenha papel relevante no âmbito da memória, do desejo, da motivação, da linguagem e do pensamento.

Segundo Aristóteles (2006 apud SAES, 2010), é impossível desejar sem usar a imaginação. Ele ainda sugere que a imaginação não tem vocação para julgar o que é verdadeiro e o que é falso, pois ela se submete a nossa vontade e podemos imaginar o que bem quisermos, diferentemente dos juízos, que não dependem da nossa vontade para serem verdadeiros ou falsos. A diferença é que os juízos mantêm um tipo de vínculo com a realidade que a imaginação, pelo seu próprio poder, não pode manter. Ele exemplifica: quando julgamos que algum acontecimento é terrível sentimos medo, pois acreditamos estar diante de algo terrível, mas quando apenas imaginamos algo terrível, podemos contemplá-lo sem sentir medo, pois é como se estivéssemos apreciando o terrível em uma pintura.

Para Descartes (1979 ${ }^{4}$ apud SAES, 2010), o ato de imaginar é formar ideias a partir das imagens geradas e alojadas no cérebro a partir das percepções sensíveis. Para ele, quando imaginamos um triângulo, não só o concebemos como uma figura composta de três linhas, mas é possível, ao mesmo tempo, visualizarmos um triângulo, fazendo sua imagem aparecer diante da mente.

\footnotetext{
3 ARISTOTELES. De anima. Trad. Maria Cecília Gomes dos Reis. São Paulo: Editora 34, 2006, livro II, capítulo 12; livro III, capítulo 3.

4 DESCARTES, René. Meditações metafísicas. Trad. J. Guinsburg e B. Prado. São Paulo: Abril Cultural, 1979. (Coleções os Pensadores), segunda meditação, § 9; sexta meditação, §§ 2 e 3.
} 
Todavia, Descartes argumenta que não é possível imaginarmos um miriágono, uma figura de dez mil lados, isto é, não conseguimos vê-lo nitidamente com os olhos do espírito (dada sua complexidade). No entanto, o intelecto puro, por conceber figuras geométricas sem o acompanhamento de imagens, consegue representar qualquer figura, seja de três ou dez mil lados, mediante noções e definições geométricas.

Para Descartes (1979 apud SARTRE, 1985), a imagem é uma coisa corporal, produzida pela ação de objetos exteriores sobre nosso próprio corpo, mediante a ação dos sentidos e dos nervos. É também um objeto como os objetos exteriores. A imaginação, a consciência da imagem, nos é dada pela aplicação do entendimento e do juízo às impressões materiais produzidas no cérebro. Assim, a distinção entre sensações, lembranças e ficções é feita pela coerência intelectual que as imagens apresentam. Para ele, a imaginação é uma faculdade destinada a integrar mente e corpo. Entretanto, ele não oferece uma explicação a respeito de como a faculdade do entendimento pode se aplicar à realidade corporal da imagem nem, inversamente, como a imagem, com sua natureza de objeto, pode intervir no pensamento.

Hume $\left(2000^{5}\right.$ apud SARTRE, 1985) amplia o conceito de percepção e classifica as percepções em duas classes: as impressões, que são percepções mais fortes e vívidas, e os pensamentos ou ideias, que são percepções mais fracas. Ele compõe o mundo da consciência apenas com os conteúdos sensíveis da percepção, mediante a duplicação da categoria da percepção com uma categoria das imagens, constituída pelos mesmos conteúdos sensíveis da percepção, porém com menor grau de intensidade. Por exemplo, "a ideia simples do vermelho difere apenas em grau (de força e vivacidade) da impressão simples do vermelho, sendo a cópia ou imagem da própria natureza do vermelho" (SAES, 2010, p. 22).

Essa tese geral é ampliada para todo o domínio mental, então, as ideias dependem das impressões para existir, isto é, as ideias são condicionadas por experiências efetivamente vividas. Por exemplo, um cego não pode ter ideia das cores, assim como uma pessoa serena não pode formar a ideia de um espírito perturbado por um desejo cruel de vingança. Hume considera que as ideias simples são cópias exatas, com menor intensidade, das impressões simples, como no caso do vermelho visto acima, mas não aplica o mesmo princípio para as ideias complexas. Quando vemos uma cidade e formamos uma ideia sobre ela não significa que essa ideia represente exatamente suas ruas e casas, mas que as impressões - sensações, sentimentos,

\footnotetext{
${ }^{5}$ HUME, David. Tratado da natureza humana. Trad. Débora Danowski. São Paulo: UNESP/Imprensa Oficial, 2000, parte I, seção I, $\S \S 1$ e 2.
} 
emoções, desejos - são os materiais com os quais a mente comporá os pensamentos e as ideias (SAES, 2010).

Kant (1994 ${ }^{6}$ apud SAES, 2010), por sua vez, nos diz que não podemos perceber as coisas-emsi, pois elas estão além da nossa capacidade de apreensão, mas só podemos perceber os fenômenos, isto é, o modo como as coisas que existem na realidade, e que podem ser objetos de nossa experiência, aparecem para nós. Assim, podemos perceber os fenômenos mediante um estado de consciência (não nos órgãos do corpo) em que as sensações causadas pelos objetos quando afetam nossos sentidos (nos órgãos do corpo) são ordenadas no espaço e no tempo pela própria consciência. Por exemplo, quando percebo uma árvore as sensações, que formam a matéria da percepção, já se encontram ordenadas segundo as relações de espaço e tempo. Ele define percepção como sensação acompanhada de consciência.

Um conceito que Kant deriva da percepção é o de intuição empírica. É empírica a intuição que se tem dos objetos unicamente mediante a sensação - intuição compreendida em seu sentido filosófico, isto é, o conhecimento direto, sem necessidade de raciocínios - assim pode-se dizer que intuição empírica é o conhecimento que adquirimos de um objeto apenas pelas sensações que ele nos provoca e que a intuição empírica é uma percepção. Kant argumenta que para haver conhecimento do objeto é necessário que haja a intuição empírica e que a ela se apliquem conceitos, de modo a formar juízos (SAES, 2010).

É conhecida a tese de KANT: "conceitos sem intuições são vazios, intuições sem conceitos são cegas". (1994 apud SAES, 2010, p. 25)

Husserl $^{7}$ (apud SARTRE, 1985) vem renovar a noção de imagem agregando a ela o conceito de intencionalidade. Para ele a intencionalidade é a estrutura essencial de toda consciência, é por meio da intenção que a consciência visa seu objeto. Segue-se que toda consciência é consciência de alguma coisa e que, consequentemente, existe uma distinção radical entre a consciência e aquilo de que se tem consciência, logo, todo objeto visado pela consciência situa-se fora da consciência.

Para Husserl (apud SARTRE, 1985) os dados impressionais (hylé), isto é, os dados visuais ou táteis antes de serem visados pela intenção, fazem parte da consciência como elementos

\footnotetext{
${ }^{6}$ KANT, Immanuel, Crítica da razão pura. Trad. Manuela P. dos Santos e Alexandre F. Morujão. Lisboa: Fundação Calouste Gulbenkian, 1994, B33, B34, B60.

${ }^{7}$ Esboço de uma fenomenologia pura e de uma filosofia fenomenológica - Ideen zu einer reinem Phänomenologie und phänomenologischen Philosophie.
} 
subjetivos imanentes, mas eles não são o objeto da consciência, a consciência mediante a intencionalidade não se dirige para eles, mas através deles visa seu objeto, que se situa fora dela. Diz Husserl:

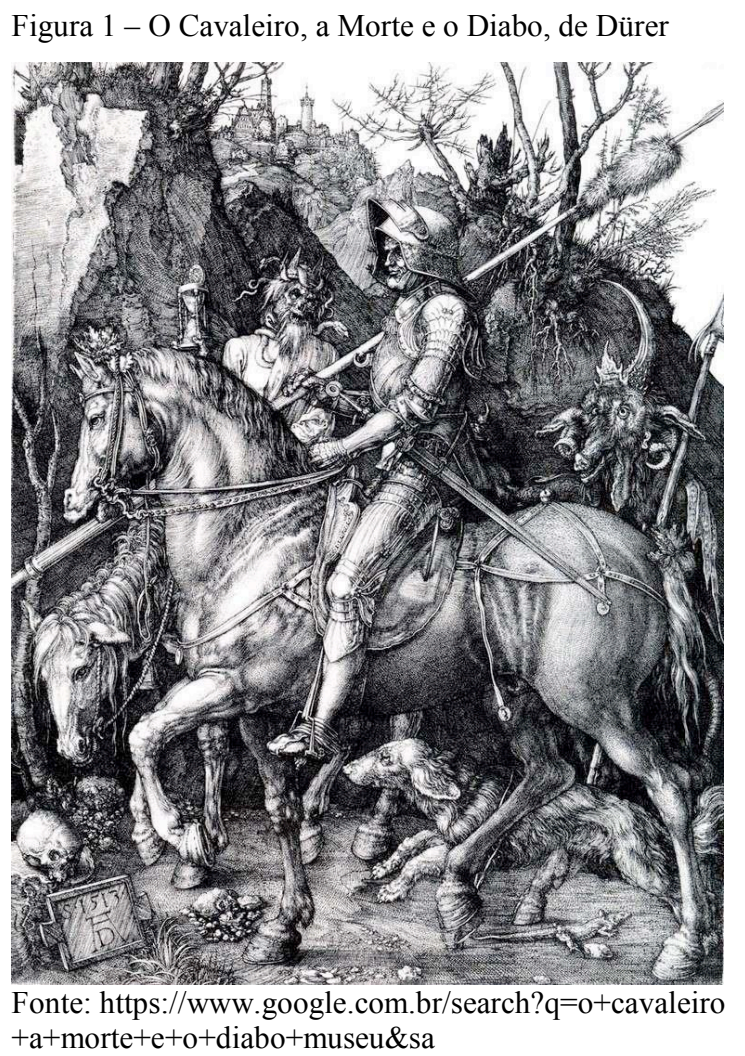

Consideremos a água-forte de Dürer, O Cavaleiro, A Morte e o Diabo. Distinguiremos em primeiro lugar aqui a percepção normal, da qual $o$ correlativo é a coisa "gravura", esta folha do álbum.

Em segundo lugar, encontramos a consciência perceptiva, na qual, através destas linhas negras, pequenas figuras incolores, "Cavaleiro a cavalo", "Morte", "Diabo", nos aparecem. Não somos, na contemplação estética, dirigidos para elas enquanto objetos: somos dirigidos para as realidades que são representadas "em imagem", mais exatamente, para as realidades "imagificadas", (abgebildt), o cavaleiro em carne e osso etc." (apud SARTRE, 1985, p. 111).

Para Sartre (1985), o texto de Husserl transcrito acima pode dar origem a uma distinção intrínseca entre percepção e imagem. Pois, a depender do tipo de estrutura intencional com que visamos a mesma matéria impressional (hylé) ela pode constituir a impressão traços negros sobre uma folha branca, objeto-coisa, ou a imagem Cavaleiro, cavaleiro de carne e osso, objetoimagem. Então, para Sartre, se a imagem não é mais do que uma certa maneira de animar intencionalmente um conteúdo impressional, "poder-se-á muito bem assimilar a apreensão de um quadro como imagem à apreensão intencional de um conteúdo ‘psíquico"” (p. 111).

Assim Sartre (1996), baseando-se no método de Husserl: a fenomenologia, e servindo-se dos conceitos por ele desenvolvidos de intencionalidade e de hylé, isto é, a matéria impressional 
antes de ser atingida por uma intenção, inaugura uma teoria da imagem que repudia a existência da imagem como coisa, isto é, a imagem se apresentando à consciência como um quadro ou como uma fotografia que sejam o resultado de resquícios da percepção que permanecem gravados na consciência. Consequentemente, repudia a consciência como sendo um lugar habitado por pequenos simulacros das coisas percebidas, que seriam resultado de resquícios da percepção.

Para ele, tanto a percepção como a imaginação são tipos de consciência que se relacionam, cada uma a sua maneira, com o objeto. Olhamos para uma determinada cadeira de madeira e a vemos, a observamos, com todas as suas particularidades, posicionada no espaço em relação a outros objetos: nós percebemos a cadeira, temos uma consciência perceptiva da cadeira. Em seguida, fechamos os olhos - a cadeira não está mais em nossa presença - e produzimos a imagem da cadeira que acabamos de perceber: temos uma consciência imaginante da cadeira. Nos dois casos - tanto quando intencionamos perceber como quando intencionamos imaginar - nossa consciência se relacionou com o mesmo objeto: aquela cadeira de madeira "em carne e osso" muito embora no primeiro caso ela estivesse em nossa presença e no segundo caso ela estivesse ausente (SARTRE, 1996).

Enquanto a consciência perceptiva dirige sua intenção diretamente a um objeto presente, a consciência imaginante visa um objeto ausente, ou inexistente, ou existente em outra parte, mediante um fenômeno intercalar, mediante uma imagem desse objeto. Essa imagem do objeto tem a função de representá-lo. No termo utilizado por Sartre (1996), a imagem age como um analogon do objeto, como um equivalente da percepção desse objeto. E não é apenas a imagem mental que pode funcionar como analogon de um objeto. A fotografia, o retrato, a caricatura, a imitação e o signo também podem funcionar como analogon de um objeto na formação da imagem, ou como simples objeto da percepção a depender da intenção com que os visamos.

Assim, diz Sartre (1996), quando visualizamos uma foto e ela aparece apenas como um pedaço de papel com qualidade e cores especiais, o fenômeno mental é de natureza simplesmente perceptiva. Mas, se nessa foto visamos alguma coisa, visamos Pierre, por exemplo, é porque o colocamos aí através de uma intenção particular, de um saber particular, que, unindo-se aos dados sensíveis contidos na foto a transformou. A foto deixou de ser um simples objeto concreto que a percepção fornece; ela passou a servir de matéria à imagem. Ela mudou de sentido, deixou de atuar como um suporte à consciência perceptiva e passou a atuar como um suporte à consciência imaginante. Em outras palavras, passou a atuar como um representante, como um 
analogon de Pierre, passou a ter a função de tornar presente o objeto visado por nossa consciência, isto é, o Pierre em carne e osso que se encontra ausente. A imagem "é um certo modo que a consciência tem de se dar um objeto" (p. 19).

Perceber, conceber e imaginar um objeto são os três tipos de consciência pelos quais um objeto pode nos ser dado. Perceber um objeto é observá-lo, apreendê-lo de vários pontos de vista possíveis. Poder vê-lo, tocá-lo, mas ao mesmo tempo só poder apreendê-lo de um ponto de vista de cada vez. A percepção de um objeto é um fenômeno que pode envolver infinitos modos de observação, e o objeto em si mesmo é o resultado de uma síntese dessas observações (SARTRE, 1996).

Quando pensamos num objeto utilizando um conceito concreto, possuímos a ideia inteira de uma vez. Não é necessário, como na percepção, unir em uma síntese uma multiplicidade de aparências. Para Sartre (1996), essa é a diferença mais nítida entre percepção e pensamento, isso explica porque é impossível perceber um pensamento ou pensar uma percepção. São fenômenos radicalmente distintos: um o saber consciente de si mesmo, que se dá de uma vez, o outro um processo que faz lentamente seu aprendizado.

A imagem, por seu lado, une elementos representativos obtidos da percepção a um saber concreto. Da mesma forma que o conceito, ela se dá inteira desde o instante de seu aparecimento. Ela nos apresenta uma síntese das observações do objeto, unidas ao saber, à afetividade e aos desejos pré-existentes relativos ao objeto (SARTRE, 1996). Então, pela razão de a imagem ser constituída apenas com os conhecimentos perceptivos, intelectuais e afetivos já existentes, Sartre (1996, p. 23) afirma que "não se pode aprender nada de uma imagem que já não se saiba antes".

Isso não implica que a imagem de um objeto não possa evoluir e expandir-se. Enquanto a consciência perceptiva é passiva, limita-se a observar um objeto presente que já está dado, a consciência imaginante é ativa, constitui seu objeto ausente como analogon a partir de conhecimentos pré-existentes.

A percepção, como foi dito acima, contém mais do que a imagem. No dizer de Sartre (1996, p. 162) "há na percepção a incitação para uma infinidade de imagens". Também o saber sobre o objeto não se esgota na imagem, "tal saber preside aos desenvolvimentos ulteriores da imagem, é ele que os orienta nesta ou naquela direção" (p. 156). A afetividade, igualmente, evolui, comporta-se diante da imagem do mesmo modo que diante do objeto real; "o estado afetivo 
segue o progresso da atenção, desenvolve-se com cada nova descoberta da percepção" (p. 184). Então, à medida que evoluem nossa percepção, nosso saber e nossa afetividade em relação ao um objeto real, sua imagem também evolui.

Uma vez que a imagem de um objeto contém as percepções, os saberes, a afetividade e os desejos do indivíduo em relação a esse objeto (Figura 2), consideramos ser possível descobrir os desejos que o indivíduo tem em relação ao objeto, a partir da exploração da imagem desse objeto.

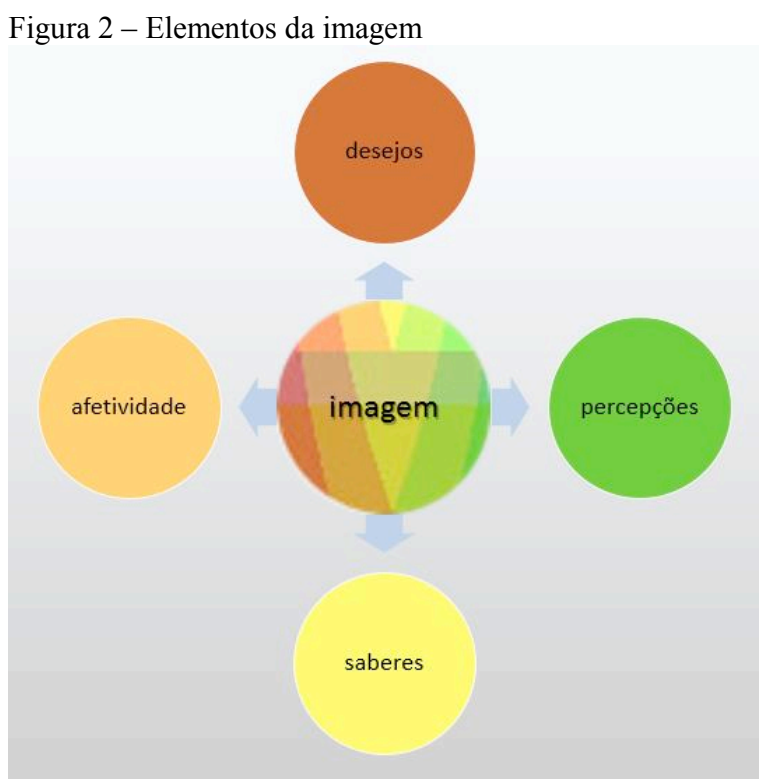

Fonte: Autor

Enquanto Sartre $(1985 ; 1996)$ aborda o imaginário de um ponto de vista psicológico, Durand (1997) estuda o imaginário a partir de uma perspectiva antropológica, ele se ocupa menos do processo de formação da imagem de um objeto, já que, fundamentado em Jung e Bachelard, assume que as leis da representação são homogêneas e que todo pensamento repousa em imagens gerais comuns ao homo sapiens, os arquétipos, que determinam inconscientemente os pensamentos. Assim, ele se ocupa do papel das imagens gerais, os arquétipos, especialmente quanto a seu caráter simbólico, na formação de conteúdos imaginários, especialmente o mito.

Para Durand (2011), o imaginário assemelha-se a um museu de todas as imagens passadas, possíveis, produzidas e a serem produzidas:

É o imenso universo do imaginário onde se subsumem imagens, símbolos, ideias, representações, e depois sintaxes, topologias, retóricas e lógicas de todos os tipos. O imaginário é o reservatório concreto da representação humana em geral, onde se vem inscrever o trajecto reversível que, do social ao biológico, e vice-versa, informa a consciência global, a consciência humana (DURAND, 1996, p. 65). 
Desse modo, o imaginário não se limita a ser um mero arquivo de representações. No homem, não há uma solução de continuidade entre o imaginário e o simbólico, portanto, “o imaginário constitui o conector obrigatório pelo qual forma-se qualquer representação humana" (DURAND, 2011, p. 41).

Portanto, a partir de Sartre (1996) e Durand (1996; 1997; 2011) podemos dizer que o imaginário contém imagens que contêm desejos, inclusive imagens relativas a uma viagem de turismo, como ilustra a figura 3 , a seguir:

Figura 3 - Elementos do imaginário

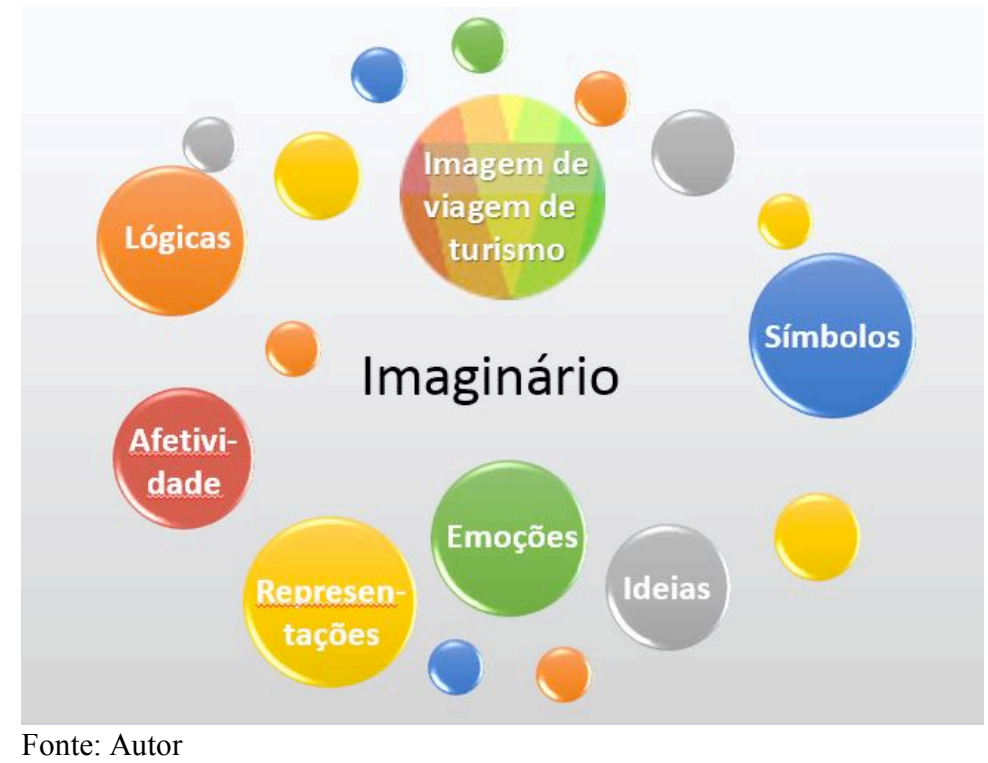

Laplantine e Trindade (1997), por sua vez, analisam as relações entre o imaginário, o real e a realidade. Esta última consiste em que as pessoas e o mundo da natureza existem em si mesmos, não dependem da nossa presença para existir, tampouco dos significados que lhes atribuímos. Essa existência em si mesma das coisas e dos homens e, consequentemente, do ambiente social e natural faz com que a realidade seja algo dado, que se faz presente independentemente de nossa percepção. O real, por sua vez, é a interpretação que atribuímos à realidade, mediante representações mentais das coisas concretas ou abstratas que constituem a realidade percebida. Já o imaginário é uma fração no campo da representação; como tradução mental de uma realidade percebida, ele filia-se ao real, porém vai além do processo mental de representação intelectual. Ele é a faculdade originária de, com apoio na percepção, fazer aparecer uma imagem e uma relação que não são dadas diretamente na percepção, que são inexistentes no real. A representação imaginária é referida ao processo de abstração e é carregada de afetividade e de emoções criadoras e poéticas. 
O processo do imaginário consiste em libertar-se do real atual e explorar todas as possibilidades que estão já contidas na realidade, mas que estão sem exercício ou sem efeito, prontas para construir um real potencial, ou seja, para elaborar representações da realidade ainda não suspeitadas, não previstas. Assim, o imaginário não apenas previne situações futuras, mas busca um futuro insuspeitado, não previsto (LAPLANTINE; TRINDADE, 1997).

Pelo exposto, é possível realizar uma viagem imaginária, desde que tenhamos a intenção de fazê-lo e possuamos, em nosso imaginário, o suporte que a imaginação demanda, isto é, as imagens relativas a uma viagem. Não importa se essas imagens se formaram a partir de uma viagem efetivamente realizada, uma propaganda turística, um relato de viagem ou uma viagem lida em um livro. De qualquer modo, elas estarão carregadas de afetividade e desejos.

\subsection{IMAGINÁRIO E JUVENTUDE}

A entrada na juventude tem um caráter universal, é marcada por transformações biológicas, psicológicas e de inserção social facilmente identificáveis, como a capacidade de gerar filhos, a busca de uma identidade, de um papel social a ser desempenhado no cotidiano, de autonomia cultural. No entanto, a saída da juventude é fluida e indeterminada, pois os ritos de passagem, encontrados comumente em pesquisas antropológicas e que marcam claramente as fronteiras etárias de um grupo social, não são nítidos na sociedade ocidental contemporânea. Os marcadores de passagem para a vida adulta, tais como finalizar os estudos, deixar a casa dos pais, conseguir emprego, obter independência financeira, casar, ter filhos, ocorrem atualmente em nossa sociedade sem um tempo pré-definido e sem uma sequência lógica ou previsível, ou ainda não ocorrem e prolongam indefinidamente a juventude de alguns indivíduos (DAYRELL; CARRANO, 2014).

No Brasil, de acordo com a Constituição Federal e o Estatuto da Juventude, bem como na América Latina em geral, os jovens são considerados até os 29 anos (DAYRELL; CARRANO, 2014). A Organização Internacional do Trabalho OIT considerava, até 2006, que a faixa etária do jovem correspondia ao período entre 15 e 24 anos de idade. Em 2007, alterou esse critério e estendeu a faixa etária até os 29 anos de idade (SOARES, 2010). Há também autores, como Pochmann (2007), que sustentam que, devido à crescente complexidade da transição da adolescência para a idade adulta e ao aumento da expectativa de vida, que atualmente ultrapassa os 70 anos e tende rapidamente para 100 anos, a faixa etária correspondente à juventude deva ser ampliada para algo entre 16 e 34 anos. A definição de juventude vinculada a uma faixa etária 
encontra objetividade na sua relação com a maturidade biológica e encontra utilidade na elaboração de políticas públicas e na distribuição de recursos orçamentários.

Contudo, para Dayrell e Carrano (2014), compreender o fenômeno juventude como vinculado exclusivamente a determinada faixa etária ou a uma idade cronológica seria simplificar uma realidade complexa condicionada por fatores sociais, históricos, culturais, econômicos. Para esses autores, a categoria juventude é socialmente produzida e sua representação se dá em função do contexto histórico, social e cultural. Ela é uma construção histórica que surge com destaque nas sociedades industriais modernas, como resultado das transformações na família, da generalização do trabalho assalariado e do surgimento de instituições como a escola. Ela também é um processo de crescimento totalizante, que guarda relação com as experiências vividas pelos indivíduos em seu contexto social, o que implica compreender a juventude de modo amplo, sem restringi-la a uma etapa com fim determinado e ainda menos com uma etapa de preparação que será superada quando da entrada na vida adulta. Os autores ressaltam ser comum a imagem da juventude como uma fase de transição, de passagem para a vida adulta. Afirmam que essa perspectiva nega o presente vivido pelo jovem e o destitui de sua identidade no presente em função do que esperamos que venha a ser no futuro.

Da mesma forma que a juventude, o imaginário "é um fenômeno coletivo, social e histórico... diz respeito a uma civilização, circula através da história das culturas e dos grupos sociais...o imaginário alimenta e faz o homem agir" (LEGROS et al., 2014, p.10). Portanto, ao nosso ver, para estudar as relações entre imaginário e juventude é imprescindível situá-los social e historicamente.

Desse modo, inicialmente, chamamos a atenção para o fato de que ruptura, novidade, inconformismo, busca por experiências e mudanças, valores tão relacionados ao imaginário de juventude, são pilares constitutivos da modernidade ocidental. Portanto, a juventude como espírito do tempo (eidos) e estilo de vida (ethos) sempre esteve subentendida na ideia de modernidade. Assim, a aceitação e a exaltação de valores ligados à juventude precederam e prepararam a sociedade para a entrada em cena dos jovens propriamente ditos, como atores sociais fundamentais, senão principais, na modernidade contemporânea (ENNE, 2010).

Historicamente, o imaginário de juventude entrou em evidência a partir do final do século XIX, quando as instituições tradicionais ainda exibiam força e destinavam os jovens ao silêncio e ao esquecimento (as mulheres silenciadas também em termos de gênero), ao mesmo tempo que a 
disposição à juventude como espírito do tempo já estava entranhada na sociedade ocidental. Com a instauração progressiva da modernidade, as formas de conduta e os hábitos foram se modificando e assumindo valores ligados à juventude. A cultura romântica da boemia ganhou fôlego por representar o espírito inquieto e inovador dos novos tempos. No início do século $\mathrm{XX}$, figuras de jovens passaram a ocupar lugar de destaque na publicidade; o corpo forte e vigoroso era celebrado nas práticas esportivas; o cinema valorizava figuras esteticamente jovens; os governos totalitários gestados nos anos 30, acreditavam no potencial renovador da juventude e a ela dirigiam grande parte de seu discurso, assumiam parte de seus valores e incorporavam indivíduos jovens aos seus quadros (ENNE, 2010).

A essa época prevalecia a ideia de futuro gerada no início da modernidade, isto é, um futuro em aberto e sob o controle do homem, não mais determinado pela influência divina nem pelas forças da natureza. Entretanto, essa concepção de futuro que colocava em evidência a autonomia do indivíduo, sua capacidade de projetar-se, de ser a fonte primária de sua identidade e o organizador de sua biografia ainda convivia com um modelo relativamente tradicional que ordenava a vida em canais mais ou menos fixos. Nesse modelo, cabia ao estado promover o progresso mediante o exercício do controle, inclusive sobre a população. A família, o trabalho e o sistema educacional influenciavam em larga medida as escolhas dos jovens a respeito de identidade, estilo de vida e plano de vida. As identidades individuais e os papéis sociais apareciam vinculados ao projeto coletivo, as biografias eram estruturadas em torno da coincidência entre as projeções coletiva e individual. Assim, a juventude era identificada como um conjunto de etapas, socialmente organizado, que conduzia o jovem ao mundo adulto. A juventude era imaginada como uma travessia marcada por etapas e passagens de status: a conclusão dos estudos, a inserção profissional a independência financeira e habitacional, a construção de um núcleo familiar autônomo (LECCARDI, 2005).

Após a última grande guerra, o imaginário de juventude sofre modificações consideráveis. A abundante produção de bens, a facilidade de acesso a esses bens e o desenvolvimento de novas práticas de consumo aliaram-se à diversificação das formas midiáticas para ampliar o uso de bens materiais como signos e, consequentemente, a capacidade de esses bens produzirem sentido. A entrada em cena da mídia televisiva e o fato de a mídia massiva dirigir-se fortemente aos jovens, especialmente nos campos imagético e musical, fez surgir uma cultura de consumo, que se caracterizou não apenas pelo acesso aos bens, mas também pelo acesso à imagem desses bens (ENNE, 2010; TASCHNER, 2010). Tocou, então, aos jovens se apropriarem dessas culturas: de consumo e midiática e, adotando o espetáculo como linguagem, manifestarem-se 
em slogans identitárias: faça amor, não faça a guerra; viva e deixe viver; é proibido proibir, dentre outros. (ENNE, 2010)

É nas décadas de 50 e 60 que surgem as figuras do rebelde sem causa, do contestador universitário de maio de 68, do hippie representante da contracultura, e demais estereótipos do imaginário mundial. (ENNE, 2010). No Brasil, vimos o surgimento, entre outros, das imagens de fã da Jovem Guarda alienado e fã da MPB intelectual e contestador; de estudante de Filosofia da USP revolucionário e estudante do Mackenzie conservador.

Em 1967, Edgard Morin ${ }^{8}$ (1987, apud ENNE, 2010) sustentava que, naquele momento, se estabelecia um processo de pedocratização em detrimento de uma gerontocracia que perdia força em função da deterioração das instituições tradicionais, principalmente, do modelo familiar patriarcal burguês e, consequentemente, do poder paterno. Ele pontificava que a juventude, como segmento social e como faixa etária, tenderia a se alinhar mais por valores geracionais do que por distinções relativas à classe social.

Portanto, é no caldeirão da afirmação dessas três culturas: jovem, midiática e consumista, que fervilhava o imaginário dos jovens do pós-guerra. Essa ebulição evaporava as imagens da família tradicional, da incontestabilidade das instituições estatais, familiares, religiosas; e sedimentava imagens de liberdade no amor, no comportamento social, na moda, na música. Até que um dia... o sonho acabou.

Nessa época, a noção de um futuro sob controle começava a diminuir progressivamente. Não devido ao retorno da influência divina ou à iminência de catástrofes naturais, mas sob a ação de riscos humanamente produzidos: risco de guerra nuclear, de mudanças climáticas, riscos ligados à utilização de energia nuclear, à ingestão de alimentos transgênicos, ao terrorismo internacional, ao empobrecimento de vastas áreas do planeta, a doenças epidêmicas como a AIDS, a gripe asiática, a doença da vaca louca, entre outros. Eles fazem com que o futuro na modernidade contemporânea passe a ser governado pela incerteza, passe a ser indeterminado e indeterminável. A ampliação das condições gerais de incerteza se projeta sobre arcos temporais extensos e mitiga a ideia de projeto. Já não é mais possível a construção de narrativas biográficas em que um evento é relacionado a outro e, ao mesmo tempo, capaz de condicioná-

\footnotetext{
${ }^{8}$ MORIN, Edgar. Cultura das massas do século XX: o espírito do tempo. Vols. 1 e 2. Rio de Janeiro: Forense Universitária, 1987.
} 
lo. Assim, a ideia de continuidade temporal é abalada e a própria ideia de projeto se esgota (LECCARDI, 2005).

A consequência para os jovens é o desaparecimento da trajetória biográfica clara que os conduzia à vida adulta. Por exemplo, se antes, no imaginário de um jovem que se formasse em engenharia, ele teria garantido um bom emprego de engenheiro que lhe proveria independência financeira e autonomia existencial, agora a sociedade não mais consegue lhe garantir um percurso previsível em direção ao mundo adulto. Desse modo, o divórcio entre identidades individuais e papéis sociais ensejou a valorização do individualismo. Concluir os estudos, entrar no mundo do trabalho, ir morar só, constituir um núcleo familiar são ações ainda hoje ligadas ao imaginário de juventude, mas desapareceram tanto sua ordem e irreversibilidade como a moldura social que lhes dava sentido e confirmava o caráter finito da fase de vida juvenil (LECCARDI, 2005).

Em suma, diante da ausência de trajetórias socialmente normalizadas em direção à vida adulta, restou aos jovens imaginar suas próprias trajetórias. Se na pré-modernidade a identidade do indivíduo, seu estilo de vida e seu projeto de vida estavam, em princípio, dados pela tradição; se até meados do século XX os papéis individual e social ainda guardavam uma relação relativamente estável. No final do século XX e agora, início do XXI, identidades e papéis sociais estão em branco, nem a tradição, nem a estrutura social podem determinar ou garantir uma trajetória segura em direção à vida adulta. Por isso, as identidades e planos de vida são construídos, principalmente, em um processo reflexivo e não mais em função de sua articulação com papéis sociais pré-determinados (GIDDENS, 2002).

Hoje em dia, da perspectiva de Giddens (2002), no contexto do processo de globalização, em que acontecimentos distantes influenciam tanto eventos próximos como a intimidade do eu, a construção da autoidentidade se torna um projeto reflexivamente organizado, "que consiste em manter narrativas biográficas coerentes, embora continuamente revisadas" (p.12). Ele ressalta que, por causa da larga amplitude da vida social atual, com a pluralização dos contextos possíveis de ação e a diversidade de autoridades em todos os assuntos, a escolha de um estilo de vida é fundamental para a constituição da autoidentidade e da atividade diária. $\mathrm{O}$ planejamento de vida reflexivamente organizado, que pressupõe a avaliação dos riscos das decisões tomadas e dos cursos de ação seguidos, é outro fator central na estruturação da autoidentidade. Ressalte-se que o sentido da expressão: estilo de vida, ora utilizada, não é aquele comumente usado na publicidade, que se refere apenas aos projetos de grupos ou classes 
mais prósperos, mas se refere também a decisões e cursos de ação adotados em condições de severa limitação material.

Esse cenário de futuro incerto e indeterminável e de separação entre identidades individuais e papéis sociais, atinge o imaginário dos jovens, porque, segundo Dayrell e Carrano (2014), eles já são capazes de refletir e de se ver como indivíduos que participam da sociedade, indivíduos que recebem e exercem influências. São capazes de elaborar perguntas como: Quem sou eu? Que rumo devo dar a minha vida? Interrogações fundamentais que precisam ser resolvidas e que remetem às questões da identidade, do estilo de vida e do projeto de vida.

Melhor dizendo, essas incertezas, típicas da transição juvenil, sugerem uma crise de identidade. Conforme Giddens (2002), "cada fase de transição tende a tornar-se uma crise de identidade", (p.138) uma vez que as "transições nas vidas dos indivíduos sempre demandaram reorganização psíquica” (p. 37). Nas culturas tradicionais, essa reorganização tomava a forma de ritos de passagem; na contemporaneidade, "o eu alterado tem que ser explorado e construído como parte de um processo reflexivo de conectar mudança pessoal e social” (p. 37). O autor denomina autoidentidade a identidade do indivíduo estruturada mediante esse processo reflexivo:

A "identidade" do eu, ao contrário do eu como fenômeno genérico, pressupõe uma consciência relativa. É aquilo 'de que' o indivíduo está consciente no termo 'autoconsciência'. A autoidentidade não é um traço distintivo, ou mesmo uma pluralidade de traços possuídos pelo indivíduo. É o eu compreendido reflexivamente pela pessoa em termos de sua biografia [...] A autoidentidade, em outras palavras, não é algo simplesmente apresentado como resultado das continuidades do sistema de ação do indivíduo, mas algo que deve ser criado e sustentado rotineiramente nas atividades reflexivas do indivíduo (GIDDENS, p. 54 , grifo do autor).

Desse modo, podemos dizer que, se antes a identidade do jovem era outorgada pela tradição, agora ela precisa ser criada pela imaginação. Se outrora os papéis individual e social estavam vinculados, agora esse vínculo é estabelecido mediante a escolha de um estilo de vida. Se no passado o futuro em aberto permitia planos de vida de longo curso, agora o futuro cada vez mais incerto e indeterminável impõe planos de vida de curta duração, que precisam ser continuamente reimaginados.

Essas demandas exigem do jovem contemporâneo o permanente exercício da imaginação criativa e o recurso ao imaginário, tanto para criar autoidentidades, quanto estilos de vida e 
planos de vida, pois a imaginação pode nos dar imagens de objetos (SARTRE, 1996) e ativar o imaginário (LEGROS et al., 2014).

Conforme Vigotski (2009), a criação imaginária depende da qualidade e quantidade das experiências vividas pelo indivíduo, posto que constituem o material para a imaginação. Bem como toda criação imaginária acontece a partir de elementos tomados da realidade e presentes na experiência anterior do indivíduo, que são combinados, recombinados, modificados e reelaborados, assim pode-se inventar um conto ou uma floresta com árvores azuis, criando até mesmo o irreal.

Mas a imaginação não se restringe aos limites estreitos das experiências anteriores do indivíduo que imagina, ou à criação de irrealidades. A partir de descrições e narrativas feitas por outrem, é possível imaginar o que nunca se viu, o que nunca foi vivenciado diretamente ou o que corresponde a algum fenômeno da realidade (VIGOTSKI, 2009).

Se, quando lemos uma notícia no jornal a respeito de uma manifestação pública, já temos a imagem de passeata, manifestante, ação policial repressiva, bombas de efeito moral, nosso imaginário pode nos aproximar da experiência de participar de uma manifestação popular que é reprimida pelas forças do Estado, podemos até mesmo sentir indignação se a passeata imaginária, da qual estamos imaginariamente participando, estiver sendo reprimida com violência.

Desse modo, com ajuda da imaginação e do imaginário podemos assimilar experiências e sentimentos alheios e, assim, ampliar nossa experiência individual, o que é relevante para o comportamento e o desenvolvimento humanos. Sob o ponto de vista de $\operatorname{Ribot}^{9}$ (apud VIGOTSKI, 2009, p. 28) "todas as formas de imaginação criativa contêm em si elementos afetivos".

De acordo com Vigotski (2009), existe uma dependência dupla e mútua entre imaginação e experiência: ora a imaginação se apoia na experiência, ora a experiência se apoia na imaginação. Mais que isso, a criação imaginária é capaz de descrever um círculo completo, isto é, é capaz de extrair elementos da realidade e devolvê-los à realidade em arranjos inéditos que passam a existir realmente e a influenciar outras coisas. É o caso de invenções como a lâmpada, o automóvel, a máquina de lavar roupa, o computador e tantas outras.

\footnotetext{
9 Ribot, Théodule Armand (1839-1916), sem referência no livro pesquisado.
} 
No entanto, seria incorreto supor que a criação imaginária só descreve esse círculo completo quando se trata de ações práticas sobre a natureza (VIGOTSKI, 2009). Basta verificar os efeitos que uma obra de arte pode produzir sobre as pessoas ou até mesmo sobre sociedades inteiras. Quantas peças de teatro, quantos filmes foram temidos e censurados, quantos livros foram queimados por governos totalitários ou autoritários por medo de sua influência sobre os pensamentos e atitudes da população? Quantos romances influenciaram intensamente uma geração, ou várias?

Da mesma forma que as invenções, os livros, as obras de arte e os filmes, as identidades, os estilos de vida e os planos de vida de um indivíduo são criados pela imaginação e pelo imaginário e, assim que encarnados e vividos, tornam-se reais e passam a influenciar a sociedade.

De certo, recorrer à imaginação e ao imaginário nunca foi tão decisivo para os jovens. Hoje, tornou-se imprescindível para eles criar uma identidade, escolher um estilo de vida e elaborar um plano de vida porque, como já foi dito, esses fatores não sofrem mais uma influência determinante, nem da tradição, nem da organização social.

Essa maior autonomia dos jovens, e dos não jovens também, em escolher seus caminhos, chega acompanhada de uma pluralidade e de uma variedade das imagens e conceitos nunca vistos, e nos envolve em um fluxo contínuo e caudaloso através de uma diversidade de mídias, como a internet, emissões de rádio e televisão, telefonia, mídias impressas e outras. Essa ampliação dos campos de possíveis para reinvenção de si está ligada ao fato de o eu e a sociedade estarem inter-relacionados em nível global às exigências de novos sujeitos para ocuparem posições de protagonismo histórico (mulheres inclusive), à maior facilidade de acesso a bens materiais, à consagração da face sígnica das mercadorias (ENNE, 2010).

Enfim, podemos constatar na mídia contemporânea que o imaginário de juventude diz respeito a uma miríade de identidades, estilos e planos de vida. Isso abrange, os nerds, os esportistas, as feministas, os defensores do meio ambiente, os pais e as mães de família, os empresários bemsucedidos, e entre muitos outros, os voluntários do Estado Islâmico e os homens-bomba. 


\section{IMAGINÁRIO, VIAGEM DE TURISMO E POLÍTICAS PÚBLICAS}

No Brasil, muitas pessoas deixam de viajar por falta de dinheiro ou porque enfrentam outros tipos de obstáculos a suas viagens: dificuldade de locomoção, necessidades especiais, idade avançada, entre outros. Essa incômoda realidade demanda vários tipos de ação para universalizar o direito ao turismo. Diga-se de passagem, direito a um turismo não apartado do convencional e de igual qualidade em termos de instalações e serviços. Dentre as ações possíveis, que podem se desenvolver em todos os setores da sociedade, como já foi dito, cabe ao Estado a elaboração de políticas públicas para que as pessoas que deixam de viajar por falta de dinheiro, ou que enfrentam outros tipos de obstáculos às suas viagens, superem esses obstáculos.

Essas políticas podem recair sobre qualquer modalidade de turismo. Quer adotemos definições conceituais, tal como: “O turismo pode ser pensado como uma gama de indivíduos, de negócios, de organizações e de lugares que, de alguma forma, se combinam para proporcionar uma experiência de viagem" (COOPER et al., 2007, p. 40); ou definições técnicas utilizadas para finalidades legais e de mensuração: “ As atividades de pessoas que viajam para locais que estejam fora de seu ambiente rotineiro a lazer, negócios ou por outros motivos e que neles permanecem por não mais do que um ano consecutivo" (OMT; UNSTAT ${ }^{10}$, 1994, apud COOPER et al., 2007, p. 41), ou adotemos a visão de alguns geógrafos e sociólogos que veem o turismo simplesmente como uma forma de mobilidade por lazer, uma dimensão de nossas relações com o mundo, que se estendem através de diferentes localidades sem balizas de tempo e espaço; o que nos permite pensar o turismo desde um flanar pela cidade em que residimos, até uma volta ao mundo (COOPER et al., 2007, p. 41-42). Podemos dizer que qualquer que seja a concepção de turismo ela abriga a possibilidade de uma política pública destinada a universalizar o acesso dos indivíduos a sua prática.

\footnotetext{
${ }^{10}$ OMT; UNSTAT, Recommendations on Tourism Statistics, WTO, Madri and United Nations, New York,
} 1994. 
Entretanto, para que uma política desse tipo tenha sucesso é necessária a adesão dos possíveis beneficiários. Isso demanda que o elaborador de políticas públicas esteja atento para conhecer e satisfazer os desejos e necessidades dos participantes, sejam eles do setor público, do setor privado, populações receptoras ou os turistas em potencial propriamente ditos.

Assim, o objetivo deste trabalho é descrever os desejos dos jovens de baixa renda em relação a uma viagem de turismo, mediante a exploração de seu imaginário. Para tanto, levamos em consideração, unicamente, as imagens relativas a uma viagem imaginada. Não levamos em conta as imagens de viagens turísticas existentes na publicidade, na educação, nas reportagens, redes sociais e outras mídias, bem como as imagens de viagens que os jovens tenham efetivamente realizado, porque tal conjunto de imagens não expressa, necessariamente, seus desejos em relação à viagem turística; não constitui, necessariamente, sua hipótese sobre o que seria a viagem de turismo ideal. Basicamente, porque eles não são os autores das imagens divulgadas pela mídia, mas meros receptores. Igualmente, a imagem que porventura tiverem de uma viagem efetivamente realizada pode não corresponder à imagem de uma viagem ideal.

Talvez seja impossível realizar a viagem que julgam ideal, mas certamente seu imaginário pode produzi-la. De acordo com Sartre, "todo dado existente, desde que colocado, é, por esse mesmo movimento, ultrapassado. Mas é preciso que seja ultrapassado em direção a alguma coisa. Em cada caso, o imaginário é essa 'alguma coisa' concreta em direção à qual o existente é ultrapassado" (1996, p. 243).

Portanto, a partir do conhecimento do imaginário dos jovens sobre a viagem turística, será possível desenvolver uma viagem, um produto turístico destinado a satisfazer esse imaginário e, ao mesmo tempo, competente para deixar uma imagem positiva após sua realização.

\subsection{IMAGINÁRIO E MOTIVAÇÃO PARA VIAJAR}

As razões, os motivos que levam o turista a viajar são variados e complexos e dependem de fatores psicológicos, econômicos, culturais e outros. Há pessoas que realizam viagens turísticas por obrigação, por motivações constrangedoras, por exemplo: a trabalho, para cuidar da saúde, para realizar determinada missão política ou cultural, para estudar. Outras realizam viagens turísticas em busca de satisfação pessoal, por motivações libertadoras, por exemplo: férias, repouso, desportos, cultura. E há as pessoas que têm motivação mista, isto é, aproveitam o tempo livre durante uma viagem obrigatória para buscar satisfação pessoal. As motivações 
constrangedoras são mais explícitas, enquanto as libertadoras são mais complexas e diferenciadas (CUNHA, 1997).

Uma pesquisa realizada em 1985 (apud KRIPPENDORF, 2001, p. 44-45), na Alemanha, apontou os resultados indicados no gráfico 1 abaixo, para a pergunta: Porque você realizou uma viagem durante suas férias?

Gráfico 1 - Porque você realizou uma viagem durante suas férias regulamentares?

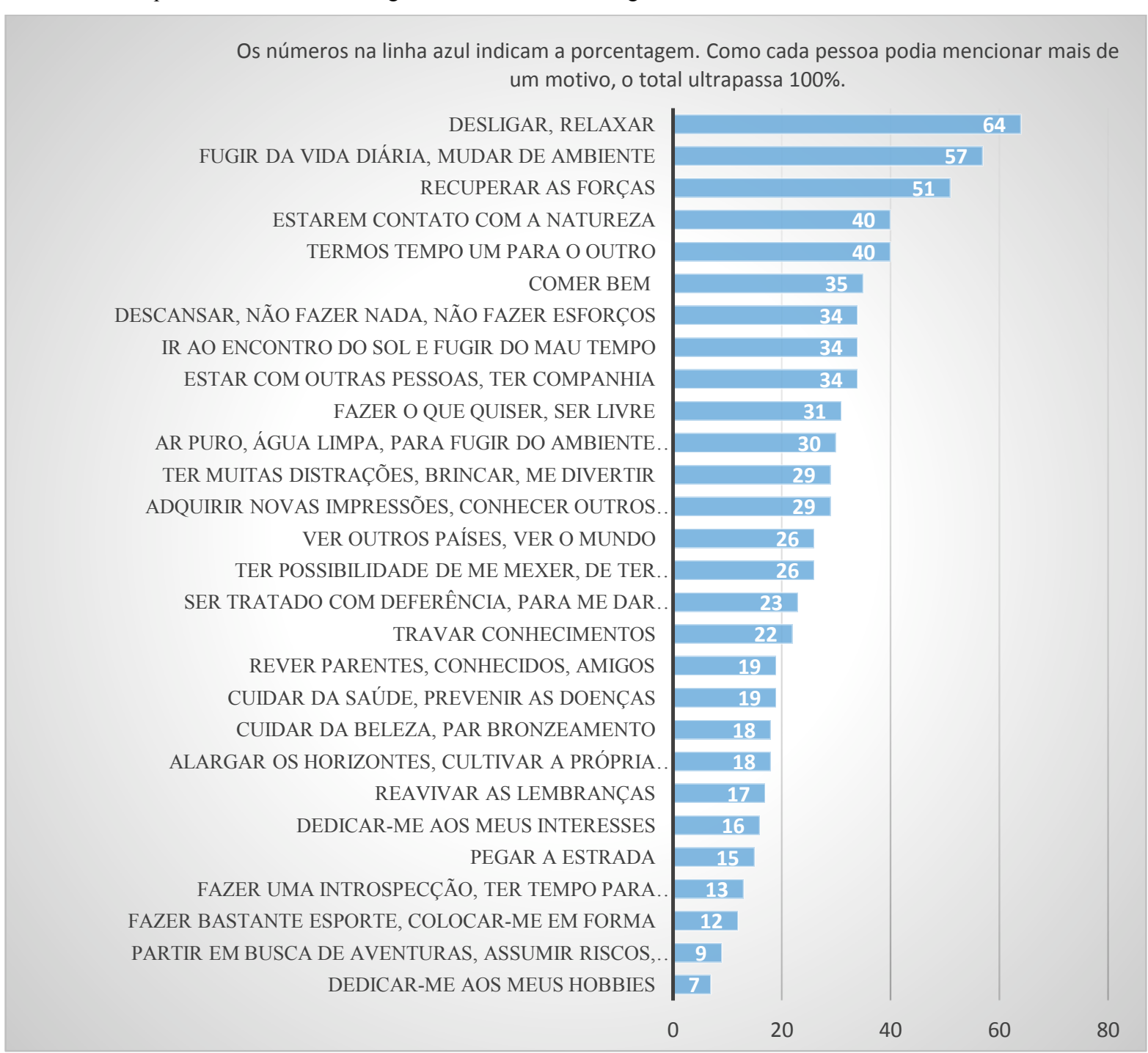

Fonte: Studienkreis für Tourismus (ed.). Urlaubsreisen 1985. Starnberg, Studienkreis für Tourismus e. V.1986. p. 30.

$\mathrm{Na}$ análise de Krippendorf (2001), apesar de as pesquisas de motivações de viagem apresentarem um panorama difuso, é possível constatar dois aspectos. O primeiro é que "a viagem é motivada muito mais pelo desejo de deixar alguma coisa do que pelo de ir para alguma coisa; o fato de escapar da vida cotidiana desempenha um papel muito mais importante do que o interesse pelas regiões e populações visitadas" (p. 50). O segundo é que as motivações de 
viagem são fortemente centradas no ego. O turista não é mais quem recebe instruções, ele as dá; quer ser mimado, tratado como um rei, enfim, ter a sensação de ser alguém.

Nota-se que na enquete alemã aparecem menções diretas e indiretas à motivação de educação para viajar, porém também se nota que essa motivação não prepondera como fator energizador e efetivador da demanda turística.

Tendo em vista que a educação não aparece na pesquisa alemã como um fator preponderante da motivação para viajar, podemos dizer que uma política pública de incentivo à prática de viagens turísticas como via de acesso à educação, ao lazer, à cultura e às artes, na Alemanha, precisa agregar outros fatores de motivação para garantir a participação de jovens, pois uma política desse tipo teria, evidentemente, caráter voluntário.

Segundo Kotler (2000, p.33), “desejos são moldados pela sociedade em que se vive”, o que implica dizer que um grupo social específico, como os jovens de baixa renda, tenha desejos específicos em relação à viagem de turismo. Ele ainda sustenta que o desejo pode ser entendido como uma necessidade humana dirigida a um objeto específico capaz de satisfazê-la, e que produto é qualquer oferta capaz de satisfazer a uma necessidade ou a um desejo: bens, serviços, experiências, eventos, pessoas, lugares, títulos patrimoniais, organizações, informações e ideias.

Em sintonia com os conceitos acima, exemplificamos:

Tabela 1 - Exemplos da relação entre necessidade, desejo e produto

\begin{tabular}{lll}
\hline NECESSIDADE & DESEJO & PRODUTO \\
\hline comida & fruta & banana \\
bebida & chá & chá preto indiano \\
roupa & calça jeans & Levis 501 \\
recreação & flanar pela cidade & Asa Sul de Brasília \\
educação & aprender se divertindo & viagem de turismo \\
entretenimento & cinema & 4 DX \\
status social & automóvel & Mercedes Benz \\
\hline
\end{tabular}

Fonte: Autor

Segundo Cooper et al (2007) as motivações de viagem explicam por que as pessoas querem viajar e representam as necessidades interiores que geram a demanda por viagens; a motivação é a chave para responder à pergunta: por que as pessoas viajam? Podemos então dizer que onde 
existe um desejo, existe a motivação para realizá-lo. A figura 4, abaixo, ilustra relações entre desejos, imaginário e viagem de turismo.

Figura 4 - Relações entre desejos, imaginário e viagem de turismo

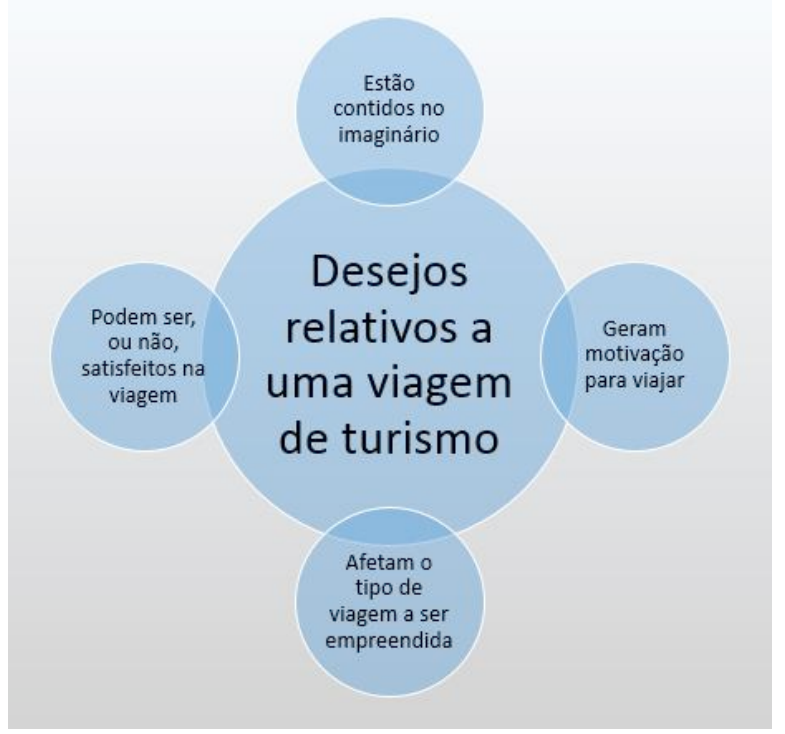

Fonte: Autor

Mesmo reconhecendo a imaturidade dos estudos que tratam do tema da motivação no turismo, Cooper et al. (2007, p. 619) nos dizem que os conceitos de motivação no contexto das viagens incluem:

- A ideia de que as viagens estão inicialmente relacionadas à necessidade, e de que esse aspecto se manifesta em termos de desejos e força da motivação, ou impulso, como energizador da ação;

- A motivação está fundamentada em aspectos sociológicos e psicológicos de normas, atitudes, cultura, percepções adquiridas, etc., o que leva a formas de motivação que são específicas de cada pessoa; e

- A imagem de um destino turístico criada através de diferentes canais de comunicação influenciará a motivação e, subsequentemente, afetará o tipo de viagem empreendida.

Uma pesquisa levada a efeito por Gilbert (1992 apud COOPER et al.,2007, p. 620), aponta as principais motivações para as viagens do Reino Unido. $\mathrm{O}$ estudo demonstra que, de modo semelhante ao que acontece na Alemanha, no Reino Unido a educação e o conhecimento também não se apresentam como um fator preponderante entre as motivações de viagem. Enquanto que, como na Alemanha, o desejo de mudança e de fuga prevalece, conforme indica o gráfico 2, a seguir: 
Gráfico 2: Variação das motivações para as viagens ao exterior a partir do Reino Unido

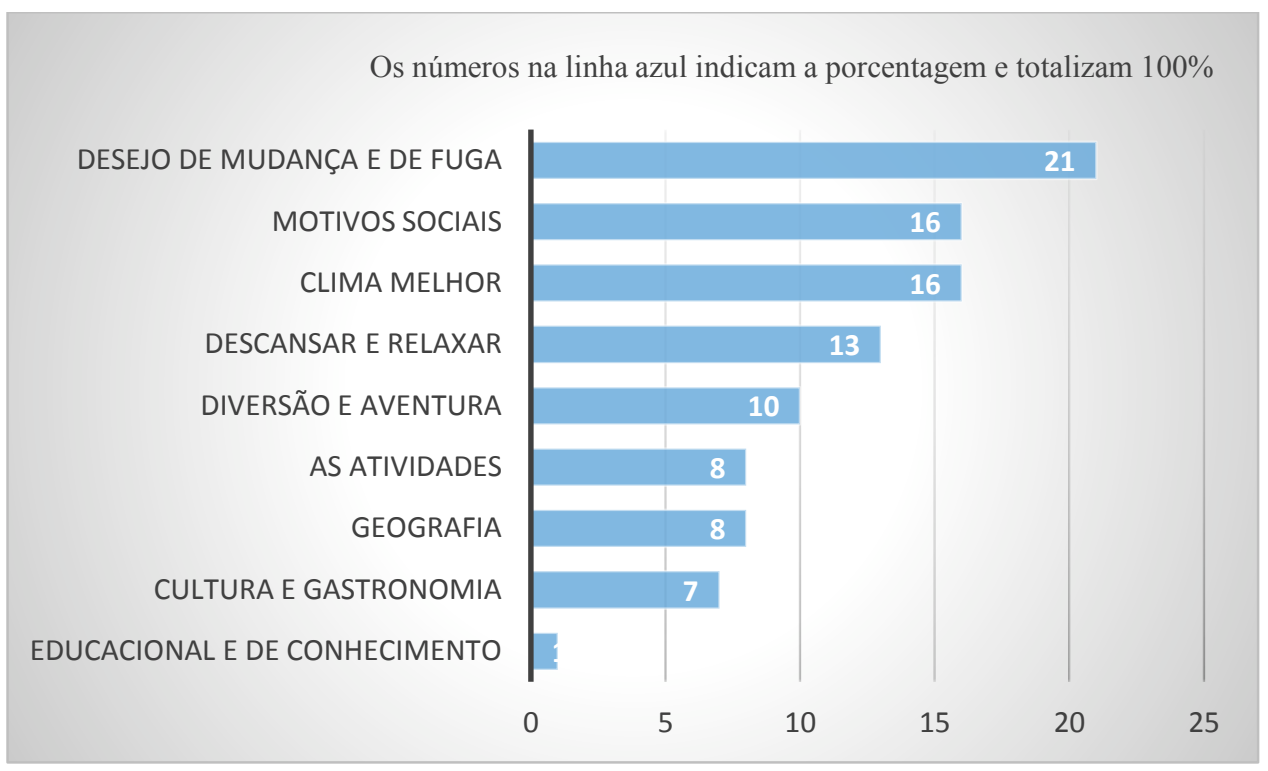

Fonte: GILBERT, D. C. A Study of Fators of Consumer Behavior Related to Overseas Holidays from the UK, Unpublished PhD Thesis (Tese não-publicada) University of Surrey, Guildford, 1992.

Se assumirmos que, como na Alemanha e no Reino Unido, também no Brasil a necessidade de educação não for um fator preponderante na motivação de viagem, então, uma viagem de turismo voltada para a educação teria mais chances de despertar a motivação de um jovem se atendesse também a outras necessidades e desejos que podem ser atendidos por uma viagem, seja o desejo de aventura, o desejo de ver belas paisagens, de conhecer outras culturas, outras pessoas, de viajar com um grupo de amigos, ou outros. Assim, ainda que sua motivação tenha sido estimulada pelo desejo de aventura e de viajar em grupo, não haveria impedimento para o atendimento de sua necessidade de educação, porque a viagem a ser realizada também visaria o atendimento de necessidades educacionais. Desse modo, não é obrigatório que uma viagem que vise principalmente a educação seja oferecida ressaltando esse aspecto.

Em poucas palavras, um jovem pode ser motivado a participar de uma viagem voltada prioritariamente para a educação movido pelo desejo de viajar em grupo, ou pelo desejo de conhecer outras pessoas, ou pelo desejo de aventura, ou outros. O relevante para a política pública é que ele se motive a participar. Então essa viagem tanto pode ser oferecida como uma viagem educativa, como uma viagem de aventura, ou como outro tipo de viagem capaz de motivar o jovem a participar.

Por exemplo, é possível apresentar uma viagem de turismo educativo à gruta do Maquiné de diversas formas:

1. Venha estudar espeleologia, paleontologia e arqueologia na gruta do Maquiné; 
2. Venha conhecer a inesperada beleza e a aura de mistério que envolvem essas formações rochosas que atraem cada vez mais a atenção dos turistas;

3. Venha desbravar territórios pouco conhecidos e habitados;

4. Venha conhecer a caverna que inspirou Guimarães Rosa ${ }^{11}$ a escrever o poema:

\section{GRUTA DO MAQUINÉ}

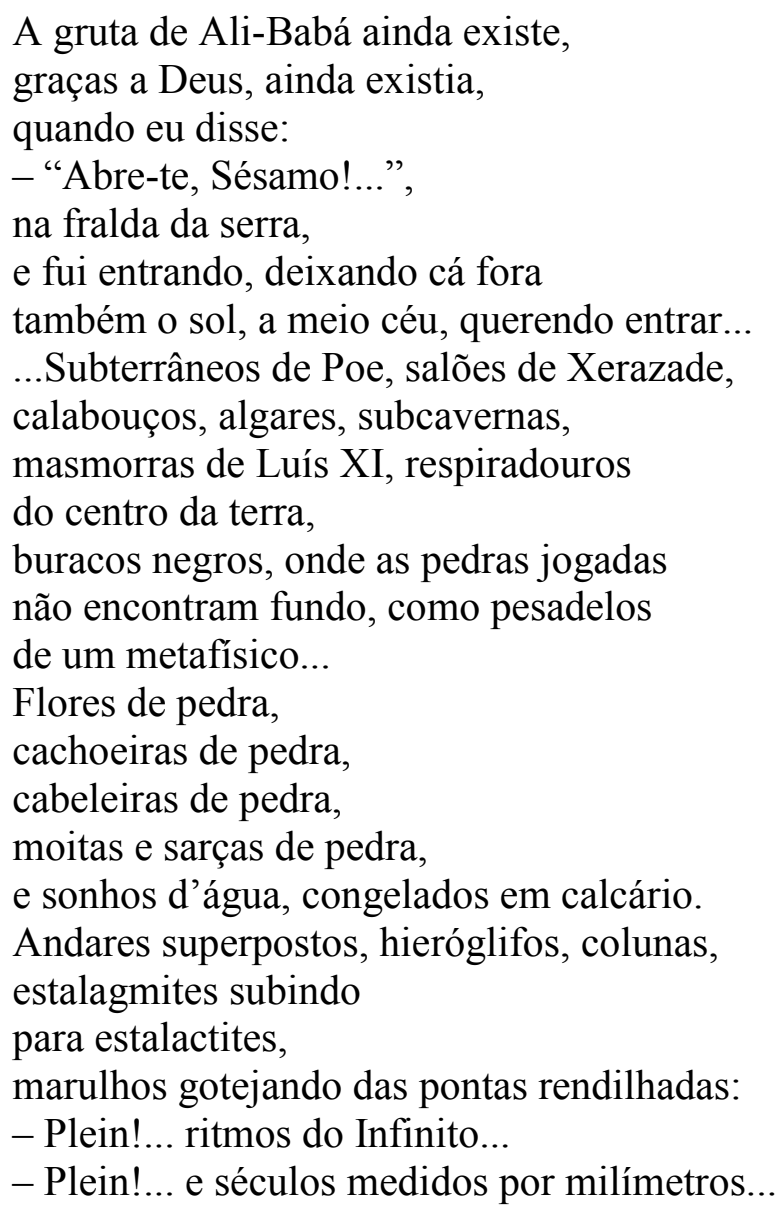

Assim, não importa a motivação que leve o jovem a viajar, uma viagem à gruta do Maquiné, orientada para a educação, será uma excelente oportunidade para que assimile novos conhecimentos sobre espeleologia, paleontologia, arqueologia, antropologia, sociologia, história, geografia, literatura, cultura, arte e outros.

No entanto, para que os jovens de baixa renda realizem viagens de turismo educacional não basta obter sua motivação para viajar, é igualmente imprescindível viabilizá-las do ponto de vista financeiro, posto que, em grande parte, declaram não viajar por não dispor de dinheiro

\footnotetext{
${ }^{11}$ Excerto do poema Gruta do Maquiné extraído do sitewww.recantodasletras.com.br/poesias/ 4436460
} 
suficiente (BRASIL, 2012a). Uma solução possível para esse problema seria realizar as viagens educativas dos jovens de baixa renda no âmbito de uma política pública de Turismo Social.

\subsection{POLÍTICAS PÚBLICAS E TURISMO SOCIAL}

Nosso país possui riquezas além do Produto Interno Bruto - PIB, das nossas reservas internacionais, da participação no comércio mundial, dos recursos que circulam pela bolsa de valores ou estão aplicados ou depositados em instituições financeiras. Possui, igualmente, riquezas que são comuns a todos os seus cidadãos e que não guardam relação direta com a posse de mais ou menos recursos financeiros. Referimo-nos a nossa multiculturalidade, nosso folclore, gastronomia, tradições, história, patrimônio histórico, artístico e cultural, metrópoles, cidades pequenas e interessantes, praias, rios, Mata Atlântica, Cerrado, Pantanal, Amazônia, interiores, flora, fauna, Enfim, tudo que pertence igualmente a todos os brasileiros e pelo que não temos que pagar para desfrutar.

Entretanto, apesar de nos serem comuns, para desfrutar essas riquezas é preciso a elas ter acesso. Para desfrutar uma praia é preciso chegar até ela, ter onde se hospedar, se alimentar. Os cidadãos que não dispõem de recursos financeiros para viajar turisticamente são alijados da fruição de nossos bens comuns, que, desse modo, ficam à disposição apenas dos mais abastados. Por isso, não basta ter direito a freqüentar esses lugares; se não for possível chegar até eles e lá viver por alguns dias, esse direito se transforma em ficção, com a consequente exclusão das pessoas de baixa renda da fruição de nossas riquezas comuns, e com o consequente aprofundamento das desigualdades sociais.

Assim, se o sistema econômico de produção em vigor gera indivíduos sem poder aquisitivo para viajar, cabe ao Estado providenciar medidas que possibilitem o acesso de todos às viagens, porque a viagem turística constitui uma via eficiente de acesso a direitos constitucionais, como lazer, educação e cultura.

Implementar políticas de Turismo Social concedendo subsídios financeiros para as pessoas de baixa renda realizarem viagens turísticas, além de ser uma forma de distribuir mais equitativamente os resultados da produção econômica, também seria uma forma de viabilizar o acesso de mais pessoas às riquezas nacionais que nos são comuns e, assim, ampliar a inclusão social. Além de diminuir o déficit educacional existente entre estudantes que têm acesso ao Turismo educativo e os que não têm. 
A Lei $\mathrm{n}^{\mathrm{o}}$ 11.771, de 2008, conhecida como Lei do Turismo, estabelece que a Política Nacional de Turismo tem entre seus objetivos: democratizar e propiciar o acesso ao turismo no País a todos os segmentos populacionais. Também estabelece que o Plano Nacional de Turismo deve ser elaborado pelo Ministério do Turismo com o objetivo, entre outros, de incorporar segmentos especiais de demanda ao mercado interno, em especial os idosos, os jovens e as pessoas portadoras de deficiência ou com mobilidade reduzida, pelo incentivo a programas de descontos e facilitação de deslocamentos, hospedagem e fruição dos produtos turísticos em geral e campanhas institucionais de promoção (BRASIL, 2008a). Como se vê, essa lei, quando prevê incentivos para incorporar segmentos especiais à demanda turística mediante programas de descontos, abre as portas para a prática do Turismo Social.

O Turismo Social não é uma atividade estranha ao conjunto das atividades turísticas, mas uma maneira de concretizar direitos humanos e constitucionais consagrados no artigo $7^{\circ}$ do Código de Ética Mundial do Turismo aprovado, em 1999 na Organização Mundial do Turismo - OMT (1999) e reconhecido pela Organização das Nações Unidas - ONU, em 2001.

A Organisation International du Tourisme Social - OITS, uma das mais influentes organizações mundiais de Turismo Social, o define como "o conjunto de relações e fenômenos resultantes da participação no turismo das camadas sociais com rendimentos modestos, participação que se torna possível ou é facilitada por medidas de caráter social bem definidas" (OITS, 2013b, tradução nossa).

Na concepção de Poplimont ${ }^{12}$ (apud GOELDNER; RITCHIE; MCINTOSH, 2002, p. 224): “O turismo social é praticado por aqueles que não poderiam pagar os custos sem uma intervenção social, isto é, sem assistência de uma associação à qual o indivíduo pertence".

Outro conceito, enunciado por Jolin (apud OITS 2013a, tradução nossa), indica que:

[...] turismo social refere-se a programas, eventos e atividades que permitem a todos os grupos da população - e, particularmente, jovens, famílias, aposentados, pessoas com baixa renda, e indivíduos com capacidade física limitada - desfrutarem do turismo, ao mesmo tempo em que atendem a qualidade das relações entre visitantes e comunidades de acolhimento..

Mais recentemente, em 2006, o Comitê Econômico Social Europeu (CESE, 2006, p. 2) afirmou que, de seu ponto de vista, o Turismo Social acontece sempre que se cumprirem as condições seguintes:

12 POPLIMONT, André. 
- Que se detecte uma situação real de incapacidade total ou parcial para exercer plenamente o direito ao turismo; tal pode resultar tanto da falta de condições econômicas, de uma deficiência física ou mental, de condições de isolamento pessoal ou familiar, de mobilidade reduzida, de dificuldades geográficas e de causas muito várias que representem, em última instância, um obstáculo real;

- Que alguém, seja uma instância pública ou privada, uma empresa, um sindicato ou simplesmente um grupo organizado de pessoas, entre em ação para vencer ou reduzir o obstáculo que impede um indivíduo de exercer o seu direito ao turismo;

- Que essa ação seja realmente eficaz e permita a um grupo de pessoas fazer turismo de uma forma que respeite valores tais como a sustentabilidade, a acessibilidade e a solidariedade.

- Por último, assim como o turismo na sua acepção comum é uma atividade que envolve vários setores, ramos de atividade e áreas de desenvolvimento, também o Turismo Social congrega um conjunto de iniciativas que permitem às pessoas com dificuldades especiais fazer turismo, produzindo, simultaneamente, benefícios sociais e econômicos para vários setores, atividades, grupos e áreas.

Por ter uma concepção mais focada nos aspectos sociais do que nos econômicos, o Turismo Social pode contribuir para maior sustentabilidade das zonas e destinações turísticas. Pois, no turismo convencional, em muitos casos, busca-se a geração de lucro em curto espaço de tempo, o que pode levar à exploração abusiva e predatória dos recursos naturais das destinações. Enquanto que no Turismo Social, a busca de resultados financeiros é feita no longo prazo, evitando eventuais abusos. Assim, do ponto de vista da sustentabilidade econômica, social e ambiental, o Turismo Social pode até mesmo contribuir para a recuperação de destinos turísticos. Trata-se de um instrumento de desenvolvimento sustentável para as regiões com potencial turístico, capaz de gerar os recursos necessários à superação da pobreza sem causar a predação dos recursos naturais.

A implementação de políticas públicas de Turismo Social no Brasil precisa considerar nossas especificidades, tais como: o imenso número de pessoas a acrescentar ao fluxo turístico doméstico; a grande extensão de nosso território e consequentemente a eventual grande distância entre destinações turísticas domésticas; a existência de uma malha rodoviária razoável e de uma indústria veículos competente; nossa multiculturalidade; o baixo grau de participação popular na formulação das políticas públicas; a quantidade insuficiente de iniciativas do terceiro setor em prol do Turismo Social; a falta de experiência brasileira em políticas de Turismo Social; a existência, ainda não mensurada, de zonas turísticas a serem exploradas; a subutilização de recursos materiais e humanos durante a baixa estação; o espírito empreendedor do cidadão brasileiro. 
A ampliação das políticas brasileiras baseadas em Turismo Social poderá trazer benefícios sociais e econômicos para significativa parcela da população. Poderá aumentar o número de empregos no setor turístico o ano inteiro, trazer rentabilidade aos empresários do setor a curto, médio e longo prazo, elevar a arrecadação de impostos, aumentar o capital cultural e social dos turistas sociais e das comunidades que os acolherem, contribuir nos processos de integração nacional e de construção de nossa identidade, promover a coincidência de interesses entre turistas, grupos econômicos e comunidades acolhedoras, e proporcionar uma experiência acessível, lucrativa e agradável a todos.

\subsubsection{Políticas Públicas voltadas para Turismo Social na Europa e no Brasil}

Ações para incluir mais pessoas nas viagens turísticas já são praticadas na Europa desde o século passado, e recebem o nome de Turismo Social. No Brasil, essa prática é recente e ainda não há uma avaliação sobre seus impactos.

O Turismo Social surgiu na Europa, no início do século passado, quando na França e na Suíça foram criadas colônias de férias para crianças de famílias desfavorecidas. Após a última guerra mundial, os poderes públicos e os sindicatos de trabalhadores em países como França, Espanha, Portugal e Itália passaram a desenvolver as primeiras formas de Turismo Social, enquanto Inglaterra e países baixos optaram por uma política de não intervenção, considerando o Turismo não como um direito, mas como uma atividade discricionária e individual. A partir dos anos cinquenta, foram fundadas, na Europa, várias organizações com vocação associativa, coordenadora e organizadora com a finalidade de promover o Turismo Social.

O Bureau International du Tourisme Social - BITS, criado em 1963, na Bélgica e transformado em OITS, em 2010, destaca-se em promover o turismo social internacional como resultado da organização entre entidades governamentais, empresas, associações de assalariados e associações específicas para seniores, jovens e pessoas com deficiência (OITS, 2013b, tradução nossa).

Em vários países da Europa, por exemplo, França, Bélgica, Espanha, o Turismo Social é subsidiado com recursos públicos, sob a forma de turismo doméstico de baixo custo. Isso acontece porque, nesses países, o turismo é visto como um direito de todos e é promovido dessa forma para diminuir as desigualdades entre os vários grupos sociais. Em outros países, como Inglaterra e Estados Unidos da América, o turismo é visto como uma atividade que pode ou não ser praticada a depender de uma decisão individual, mas não é visto como um direito. Portanto, 
na Inglaterra e nos Estados Unidos o Turismo Social é financiado em grande parte por instituições de caridade (MINNAERT; MAITLAND; MILLER, 2009, tradução nossa).

No Brasil, podemos citar alguns projetos concebidos pelo MTur, como baseados no conceito de Turismo Social, porque suas estratégias para promover o turismo baseiam-se em subsidiar as viagens turísticas. São eles:

- Turismo Acessível (BRASIL, [201-]), que desenvolve diversas ações com respeito ao turismo acessível e apoia projetos que visam à acessibilidade urbana e à adaptação de atividades turísticas a pessoas com deficiência;

- Viaja Mais Melhor Idade (BRASIL, 2007), que foi uma campanha para aumentar o acesso do público idoso ao turismo;

- Férias do Trabalhador Brasileiro (BRASIL, 2010c), que consistiu em um pacote de sete diárias a serem utilizadas durante a baixa estação, em uma rede de 100 hotéis, mediante 12 pagamentos mensais;

- Viaja Mais Jovem (BRASIL, 2009), destinou-se a grupos de estudantes acompanhados por professores com viagens de três dias, voltado para a geração de experiências complementares ao ensino em sala de aula, sem custo para os estudantes.

Recentemente, com o objetivo de incentivar os brasileiros a viajarem pelo nosso país, o Ministério do Turismo relançou três dos projetos citados acima, mediante a edição da Portaria $\mathrm{n}^{\mathrm{o}} 228$, de 3 de setembro de 2013 (BRASIL, 2013b), que institui o Programa Viaja Mais, composto por três projetos: Projeto Viaja Mais Melhor idade; Projeto Viaja Mais Jovem; e Projeto Viaja Mais Trabalhador. A referida portaria institui, de imediato, apenas a segunda edição do Projeto Viaja Mais Melhor Idade, que tem por finalidade a inclusão social dos idosos, aposentados e pensionistas, mediante a concessão de descontos em viagens turísticas.

\subsubsection{0s benefícios do Turismo Social}

O Comitê Econômico Social Europeu - CESE é um órgão consultivo da União Europeia, fundado em 1957, emite pareceres sobre as propostas legislativas da União Europeia e elabora pareceres de sua própria iniciativa sobre assuntos que julga deverem ser tratados. Em janeiro de 2006, emitiu um parecer sobre o Turismo Social na Europa aconselhando os países a desenvolverem iniciativas de Turismo Social e reconhecendo os seguintes benefícios vinculados a essa modalidade de turismo (CESE, 2006). 
- Contribuição para a socialização. O turismo promove o contato com outras realidades culturais e geográficas e com outras pessoas, fazendo todos se reconhecerem como iguais em essência, apesar das diferenças culturais. O seu valor é maior para os jovens, pois aprimora sua formação intelectual e enriquece sua visão do mundo.

- Contribuição para a criação de estruturas de turismo sustentável. O Turismo Social tem uma visão mais voltada para as condições sociais do que para os aspectos econômicos, portanto, não busca rentabilidade em curto prazo, que é, geralmente, o fator que determina a utilização abusiva dos recursos naturais. Assim, o Turismo Social pode ser uma forma de desenvolvimento sustentável para os países que veem o turismo como fonte de atividade econômica.

- Contribuição para o desenvolvimento econômico local. O turismo é capaz de contribuir para o nível de emprego, o desenvolvimento, a prosperidade e a qualidade de vida da população das destinações turísticas. O Turismo Social tem capacidade de impor a sustentabilidade nas destinações e precisa ser organizado de modo a reduzir os efeitos da sazonalidade.

- Contribuição para o desenvolvimento mundial. Turismo significa acolhimento, intercâmbio, comunicação, amizade entre as pessoas, em total oposição à guerra que significa invasão e destruição da natureza. O turismo é um instrumento de aproximação dos povos e de promoção da paz. O Turismo Social pode e deve disseminar seus ideais de igualdade, justiça e bem-estar a todos os povos do mundo.

\subsection{TURISMO SOCIAL E JOVENS DE BAIXA RENDA}

É possível classificar o conjunto dos jovens de baixa renda sob várias denominações e analisálo de várias formas, em função de diferentes pontos de vista. Para ilustrar algumas possibilidades: do ponto de vista econômico, podemos classificá-lo pela renda ou pelo tipo de ocupação e denominá-lo de baixa renda; pelo ponto de vista do marketing, podemos classificálo pelo potencial de consumo e denominá-lo classe D; pelo ponto de vista sociológico, podemos classificá-lo pelas ideias de valores, crenças e estilos de vida e denominá-lo classe trabalhadora.

Em sociologia, podemos considerar duas perspectivas polares de classe social. Num extremo o conceito marxista, que se refere a um grupo estruturalmente delimitado, com consciência de seu lugar na produção, e com estilos de vida, padrões de comportamento e projetos de sociedade diferentes dos demais grupos sociais. No outro extremo, temos a perspectiva weberiana, que se atém a características mensuráveis, como renda, educação e ocupação, deixando em suspenso 
a consciência de classe e assumindo que se o grupamento tem consciência de seus interesses coletivos ou se trata de um agregado desprovido de tais características, só a pesquisa empírica pode determinar, assim, a consciência de classe não faz parte dessa definição (SOUZA; LAMOUNIER, 2010).

A compreensão das classes sociais apenas como produto de sua renda diferenciada, ou apenas como consequência de seu lugar econômico na produção, ou ainda supor que a consciência de classe se forma unicamente em função desse lugar econômico, equivale a uma redução economicista que encobre todos os fatores e precondições sociais, emocionais, morais e culturais que integram o diferencial das classes sociais, levando a uma confusão entre causa e efeito. "Esconder os fatores não econômicos da desigualdade é de fato, tornar invisível as duas questões que permitem efetivamente 'compreender' o fenômeno da desigualdade social: a sua gênese e a sua reprodução no tempo" (SOUZA, 2010, p. 23).

Classes sociais não são determinadas simplesmente pela renda, ou pelo lugar na produção, mas por uma visão prática do mundo, que se materializa em comportamentos, ações, reações e em todo tipo de atitude concreta consciente ou inconsciente. Classes sociais são determinadas também pela apropriação diferenciada de capital econômico e de capital cultural. Nas classes altas prevalece o capital econômico, embora algum capital cultural também esteja presente; nas classes médias prevalece o capital cultural, embora algum capital econômico também esteja presente; nas classes baixas não estão presentes de forma significativa nem o capital econômico nem o cultural, tampouco as precondições sociais, morais e culturais que permitem a ampliação de sua apropriação. Classes sociais são, por outro lado, determinadas pela capacidade de transferir bens materiais e imateriais às novas gerações (SOUZA, 2010).

As políticas econômica e social levadas a efeito nas últimas décadas, no Brasil, têm conseguido combinar ampliação da renda per capita com redução no grau de desigualdade na distribuição pessoal da renda do trabalho. Esses resultados estão associados às modificações na estrutura produtiva que têm gerado uma grande quantidade de postos de trabalho com remuneração próxima do salário mínimo - dos 2,1 milhões de vagas abertas anualmente, em média 2 milhões encontram-se na faixa de até 1,5 salário mínimo mensal - e a uma política persistente de valorização do salário mínimo. Desse modo, uma grande parcela da força de trabalho conseguiu superar a condição de pobreza (POCHMANN, 2012). 
Entretanto, embora não possa mais ser classificada como pobre, essa grande parcela da população ainda não dispõe de recursos financeiros suficientes para realizar as viagens turísticas (BRASIL, 2012b), o que demanda a elaboração de políticas públicas para sua inclusão nessas viagens.

O elevado número de jovens de baixa renda na sociedade brasileira torna imprescindível que políticas públicas destinadas a incluir esses cidadãos nas viagens de turismo avaliem os impactos decorrentes do aumento do fluxo de turistas nas destinações, e proponham práticas de turismo orientadas para a preservação da natureza e das demais coisas comuns, buscando a redução dos impactos negativos nas culturas das destinações turísticas e uma distribuição mais equânime dos resultados econômicos produzidos pelo turismo, objetivos que coadunam perfeitamente com os ideais do Turismo Social.

Essa avaliação de impacto, que consiste na identificação dos efeitos potenciais e reais de uma política pública, deve ser feita de modo prévio e também de modo sucessivo. A avaliação prévia é uma análise dos efeitos potenciais da política pública e a avaliação sucessiva é uma análise dos efeitos reais produzidos pela política, ela deve controlar se os efeitos esperados realmente aconteceram, bem como ajuizar acerca da conveniência ou necessidade de correções. Tanto a avaliação prévia quanto a sucessiva envolvem a identificação do problema a ser superado e dos objetivos a atingir; a identificação de custos, benefícios e outros impactos; e a realização de consultas aos destinatários das políticas e às entidades envolvidas, sendo que cabe à avaliação sucessiva aferir o grau de sucesso da avaliação prévia (MORAIS, 2010). 


\section{DESEJOS DO IMAGINÁRIO DE VIAGEM DOS JOVENS DO PRONATEC NO DISTRITO FEDERAL - PROCEDIMENTOS METODOLÓGICOS}

A adoção de uma abordagem qualitativa nesta pesquisa se justifica pela natureza do seu objeto, isto é: o imaginário, mais especificamente o imaginário sobre viagens turísticas dos jovens de baixa renda. Esse objeto tem características descritas por Sartre (1996) e Durand (1994) que o tornam resistente ao método quantitativo.

Primeiramente, na perspectiva de Sartre (1996) o objeto como imagem é um irreal, parece que está presente, mas não podemos tocá-lo, ou melhor, podemos tocá-lo apenas irrealmente, em imaginação. "De um modo geral, não apenas a própria matéria do objeto é irreal: todas as determinações de espaço e tempo às quais está submetido participam dessa irrealidade" (p. 167). É fácil ver que o espaço da imagem não é o da percepção. Embora o objeto irreal seja contemporâneo da consciência que o forma e o tempo da consciência seja real, não podemos nos esquecer que o objeto da consciência difere por natureza da consciência da qual é o correlativo. Esse autor exemplifica: podemos imaginar Pierre em seu quarto na rua D., mas nem Pierre nem o quarto estarão situados em relação a nosso espaço real, em relação a nosso corpo. Do mesmo modo, o tempo de um objeto irreal é também irreal. Se representamos um centauro é fácil constatar que ele não pertence ao passado, nem ao presente, nem ao futuro. A consciência para a qual o centauro aparece está no presente, mas não o centauro.

Diz Sartre (1996, p. 127-128) que "jamais poderemos reduzir efetivamente uma imagem a seus elementos, pela razão de que uma imagem, como também todas as sínteses psíquicas, é outra coisa e mais que a soma de seus elementos".

Em consonância com Sartre (1996), Durand (1994) tem como perspectiva que as manifestações mais típicas do imaginário: o sonho, o onírico, o rito, o mito, a narrativa da imaginação não se enquadram na lógica clássica que se expressa em silogismos do tipo: Sócrates pertence ao gênero humano, todo homem é mortal, logo Sócrates é mortal, etc., porque essa lógica se assenta nas formas a priori de percepção, se fundamenta em uma concepção de espaço que 
delimita e separa; e em uma noção de tempo assimétrico, em que o depois só existe precedido por um antes.

Ainda segundo esse autor, a lógica do imaginário, ou sua alógica ${ }^{13}$, é outra. Na lógica do imaginário o tempo é não-assimétrico, passado e futuro independem entre si. É possível voltar no tempo e alterar os eventos, é possível reinterpretá-los, é possível repeti-los indefinidamente. Na lógica do imaginário o espaço não separa.

Continuando o raciocínio de Durand (1994), um dos corolários das concepções de tempo nãoassimétrico e de espaço que não separa é que, na lógica do imaginário, não é possível identificar um objeto fixando-o no tempo e circunscrevendo-o em um espaço, criando para ele uma identidade exclusiva. Assim, os elementos do discurso imaginário, embora sejam identificáveis, não têm uma identidade única, eles mantêm entre si uma relação semântica que os torna solidários e inseparáveis, e que lhes confere uma pluralidade de identidades que impede sua localização em uma taxinomia clássica como a das espécies animais e vegetais, baseada em identidades exclusivas agrupadas em um gênero comum.

Essa relação semântica que interliga os elementos do discurso funda o princípio da redundância do discurso imaginário observado por todos os mitólogos. "O mito não raciocina nem descreve: ele tenta convencer pela repetição de uma relação ao longo de todas as nuanças possíveis" (DURAND, 1994, p. 86). A contrapartida dessa redundância do discurso é que cada uma de suas unidades semânticas (os mitemas) é portadora de uma mesma verdade relativa à totalidade do discurso, à maneira de um holograma nos termos de Edgar Morin.

Portanto, para Durand (1994), o imaginário nas suas manifestações, como o onírico, o rito, o mito, a narrativa da imaginação contém identidades não-localizáveis, um tempo nãoassimétrico, a redundância e a metonímia holográfica que definem uma lógica diversa em relação à lógica ocidental clássica do silogismo ou da descrição eventualista. A lógica do imaginário é mais próxima da lógica da música, que se assenta nas variações de um tema e na redundância de um refrão.

Diante da natureza do nosso objeto, adotamos a abordagem da pesquisa qualitativa nas ciências sociais, que busca entender o fenômeno fora de contextos estruturados como laboratórios, sobretudo na possibilidade de imersão no cotidiano do objeto estudado (GIBBS, 2009). Nessa

\footnotetext{
${ }^{13}$ O pensamento privado de determinações lógicas e, assim, situado a igual distância do lógico e do ilógico, conforme dicionário do Aurélio.
} 
perspectiva, considerando o caráter eminentemente exploratório do estudo, adotamos como instrumento de pesquisa a entrevista qualitativa, face a face, seguindo um protocolo de questões ${ }^{14}$, deixando o respondente se manifestar com total liberdade, com a intenção de obter um referencial de seu imaginário relativo à viagem turística.

Devido à natureza do objeto, decidimos realizar entrevistas com um número reduzido de participantes, com o objetivo de obter uma pesquisa em maior profundidade.

Os critérios adotados para a definição do perfil dos participantes e respectivas justificativas encontram-se na tabela abaixo:

Tabela 2 - Critérios de definição das características dos participantes

\begin{tabular}{clll}
\hline & & Seis Jovens & Justificativa \\
\hline 1. & Idade & 18 a 24 anos & Definição da faixa etária de jovem pelo IBGE \\
2. & Estado civil & Solteiros & Maior disponibilidade de tempo para viajar \\
3. Gênero & 3 Homens & Proporção de gênero encontrada na população \\
4. & Renda & 3 Mulheres & Baixa renda de acordo com o IBGE \\
5. & Residêniciliar & Distrito Federal & Local apropriado ao pesquisador \\
6. & Viagem turística & Não realizou nos últimos & Objeto de estudo relacionado ao imaginário \\
\hline Fonte: Autor & 3 anos &
\end{tabular}

Fonte: Autor

Por consequência, decidimos selecionar seis jovens, três homens e três mulheres. A proporção de gênero escolhida espelha a porcentagem entre homens e mulheres dessa faixa etária existente na sociedade brasileira atualmente, 11.965 .621 e 11.912 .569 , respectivamente pelo Censo Demográfico de 2010 (BRASIL, 2010a).

Tendo conhecimento de que o Programa Nacional de Acesso ao Ensino Técnico e Emprego PRONATEC, nos termos da lei no 12.513, de 2011 (BRASIL, 2011), atende, prioritariamente, estudantes do ensino médio da rede pública, trabalhadores e beneficiários dos programas federais de transferência de renda, julgamos que seria provável encontrar participantes do programa com o perfil requerido pela pesquisa. Então, dirigimo-nos ao Instituto Federal de Brasília - IFB: uma instituição pública que recebe alunos de todas as regiões administrativas do Distrito Federal, e que é executora do PRONATEC. O IFB compõe a Rede Federal de

${ }^{14}$ APÊNDICE B - Protocolo da entrevista qualitativa (CRESWELL, 2010). 
Educação Profissional, Científica e Tecnológica. Oferece Educação Profissional gratuita, na forma de cursos e programas de formação inicial e continuada de trabalhadores (FIC), educação profissional técnica de nível médio e educação profisssional tecnológica de graduação e de pósgraduação, articulados a projetos de pesquisa e extensão. A criação e expansão do IFB faz parte de um programa específico do Ministério da Educação (MEC). Cabe ao IFB executar diversos programas estabelecidos pelo governo federal, entre eles o PRONATEC.

Ao contatar o diretor da instituição, declaramos nossa condição de mestrando em Turismo e nosso interesse em realizar uma pesquisa com os jovens estudantes. Com sua autorização para a realização deste estudo, entramos em contato direto com os alunos. Frequentamos por alguns dias a sala de aula do curso de mecânica automotiva e também a sala do curso de língua inglesa - os únicos disponíveis naquele momento - dialogando com os jovens durante os intervalos e participando de comemorações na escola. Assim, tivemos a oportunidade de conhecer a linguagem e a cultura dos entrevistados, como indicam Denzin e Lincoln (1998).

Após esse contato inicial, comunicamos que gostaríamos de contar com voluntários para a realização de uma pesquisa que seria feita mediante entrevistas, e que o tema da pesquisa era o imaginário dos jovens de baixa renda sobre as viagens de turismo. Apresentaram-se alguns voluntários para participar da entrevista, os primeiros três homens e as primeiras três mulheres considerados conformes aos critérios constantes na tabela 2 foram convidados a assinar $o$ Termo de Consentimento Livre e Esclarecido ${ }^{15}$, cientes de que seriam gravados em áudio. Apresentamos a seguir a tabela 3 contendo o perfil dos jovens selecionados ${ }^{16}$ :

Tabela 3 - Características dos participantes

\begin{tabular}{lcllccc}
\hline Jovens & $\begin{array}{c}\text { Idade } \\
\text { anos }\end{array}$ & Sexo & $\begin{array}{c}\text { Estado } \\
\text { civil }\end{array}$ & Resid. & $\begin{array}{c}\text { Renda } \\
\text { Domiciliar }\end{array}$ & Viagens há mais de 3 anos \\
\hline Daniele & 21 & Fem. & Solt. & Estrutural & 0 a 4 sal. & Nunca viajou \\
Eliane & 19 & Fem. & Solt. & Estrutural & 0 a 4 sal. & Uma a São Paulo \\
Felipe & 19 & Masc. & Solt. & Ceilândia & 0 a 4 sal. & Nunca viajou \\
Manoel & 23 & Masc. & Solt. & Ceilândia & 0 a 4 sal. & Uma a Salvador \\
Roberto & 18 & Masc. & Solt. & Taguatinga & 0 a 4 sal. & Nunca viajou \\
Sara & 20 & Fem. & Solt. & Estrutural & 0 a 4 sal. & Nunca viajou \\
\hline
\end{tabular}

Fonte: Autor

\footnotetext{
15 APÊNDICE C- Termo de Consentimento Livre e Esclarecido

16 Nomes fictícios
} 
Posteriormente, no momento da entrevista, em uma sala vazia da secretaria da escola, procuramos reunir o maior número possível de informações sobre o imaginário de cada jovem selecionado sobre as viagens turísticas. Para tanto, aplicamos o protocolo de entrevista previamente elaborado para obter como respostas narrativas imaginadas, e seguimos as recomendações de Atkinson (1998) quanto a: fazer da entrevista uma conversação direcionada; ser bom ouvinte quando o entrevistado fala, sem interpretar; ser responsivo e flexível para que o outro dê mais detalhes; ser um bom guia, saber o quê, o como e o quando perguntar; ser agradecido e ético.

$\mathrm{Na}$ aplicação dos procedimentos de análise, levamos em conta, além dos conceitos de imagem e imaginário já mencionados, as observações de Legros et al. (2014) a respeito da interpretação do imaginário social. Eles afirmam que a primeira assinatura do imaginário social foi feita por Durkheim $^{17}$ (1991/1912 apud LEGROS et al., 2014, p. 56) ao referir-se a uma síntese supraindividual das consciências dispersas:

Todo um mundo de sentimentos, de ideias, de imagens que, uma vez nascidos, obedecem às leis que lhes são próprias. Eles se chamam, se empurram, se fundem, se segmentam, proliferam sem que todas essas combinações sejam diretamente comandadas e necessitadas pelo estado de realidade subjacente.

De acordo com Legros et al. (2014, p. 235): "Imaginário e realidade são dois mundos que se visitam constantemente". O imaginário não é uma forma social escondida, secreta ou inconsciente que vive sob o tecido social, mas ele estrutura o entendimento humano. Sua interpretação pressupõe que seja preciso descobrir alguma coisa que não esteja evidente naquilo que se mostra à primeira vista. A análise dos imaginários demanda uma reflexão sobre as intenções do criador do imaginário, o suporte de que se serviu para sua criação, as trocas entre as representações e os imaginários.

Isso posto, após a degravação cuidadosa das entrevistas, analisamos o conteúdo do referencial coletado em relação ao nosso tema, ou seja, procedemos a uma análise temática das narrativas imaginadas produzidas nas entrevistas, buscando nelas o tema: desejos relativos a uma viagem turística.

A escolha da análise temática, deve-se a que as manifestações do imaginário se baseiam nas variações de um tema que se repete como um refrão (DURAND 1994).

${ }^{17}$ DURKHEIM, Émile. Las formes élémentaires de la vie religieuse. Paris: Le Livre de Poche, 1991/1912. 
Assim, a análise temática aplica-se ao nosso caso porque: "as respostas a questões abertas, as entrevistas individuais ou em grupo [...] podem ser, e são frequentemente, analisados tendo o tema por base" (BARDIN, 2002, p. 106). Explicando melhor:

$\mathrm{Na}$ verdade, o tema é a unidade de significação que se liberta naturalmente de um texto analisado segundo certos critérios relativos à teoria que serve de guia à leitura. [...] Fazer uma análise temática, consiste em descobrir os "núcleos de sentido" que compõem a comunicação e cuja presença, ou frequência de aparição podem significar alguma coisa para o objetivo analítico escolhido (BARDIN, 2002, p, 105).

Apesar de adotarmos a concepção de Durand (1994), já indicada neste trabalho, de que os elementos do imaginário têm uma pluralidade de identidades que impede sua categorização baseada em identidades exclusivas agrupadas em um gênero comum, levamos a efeito um tipo de categorização, com o objetivo de perceber índices invisíveis no nível dos dados brutos. No entanto, para mitigar a influência do pesquisador na definição das categorias do tipo desejo de..., tomamos a cautela de titular as categorias a posteriori, após uma análise progressiva dos elementos. Conforme indica Bardin (2002, p. 119):

A análise de conteúdo assenta implicitamente na crença de que a categorização não introduz desvios no material, mas que dá a conhecer índices invisíveis, no nível dos dados brutos. [...] A categorização tem como primeiro objectivo, fornecer, por condensação, uma representação simplificada dos dados brutos. [...] A categorização pode empregar dois processos inversos:

- É fornecido o sistema de categorias e repartem-se da melhor maneira possível os elementos [...]

- O sistema de categorias não é fornecido, antes resultando da classificação analógica e progressiva dos elementos. [...] O título conceptual de cada categoria, somente é definido no final da operação.

Entretanto, deve ficar ressalvado que as categorias adotadas não são portadoras de uma identidade única, mas de uma identidade plural, posto que são constituídas a partir de elementos do imaginário.

Para realizar a análise temática, adotamos procedimentos adaptados a partir dos passos metodológicos propostos por Bardin (2002) e Jovchelovith e Bauer (2002).

Inicialmente, selecionamos frases de cada entrevista que, direta ou indiretamente, se relacionavam com desejos; em seguida, tendo em vista nosso objetivo de encontrar desejos a partir do imaginário coletivo dos entrevistados, agrupamos as frases portadoras da mesma unidade de sentido de modo a obter unidades de contexto referentes a todas as entrevistas; 
depois, parafraseamos cada um desses grupos de frases em uma unidade de significação, buscando uma categorização dos núcleos de sentido, que se concretizou em títulos conceptuais de categorias do tipo: desejo de...

A realização desse procedimento resultou na descrição de uma série de desejos relacionados ao imaginário de viagem dos jovens entrevistados. 


\section{DESCRIÇÃO E ANÁLISE DOS DESEJOS DE UMA VIAGEM IMAGINADA}

Para atingirmos nosso objetivo geral, que é descrever desejos que podem estimular a motivação de jovens de baixa renda para participar de políticas públicas voltadas para a prática do turismo, como via de acesso à educação e ao lazer, passamos a analisar os desejos contidos nas narrativas de uma viagem imaginada, obtidas mediante entrevistas com jovens estudantes do PRONATEC-DF, quanto à possibilidade de serem satisfeitos no âmbito de uma política pública de Turismo.

Como já foi mencionado anteriormente, o imaginário é influenciado por fatores sociais, culturais, históricos, econômicos, que precisam ser levados em conta em sua análise, pois constituem a realidade sobre a qual o imaginário precisa se apoiar. Assim apresentamos mais informações sobre os entrevistados, que pudemos obter na escola, além do perfil desejado para a pesquisa.

Durante os breves períodos em que convivemos com os entrevistados, constatamos que todos eram de família de baixa renda, estudavam no período noturno porque trabalhavam ou estavam à procura de emprego.

Os três homens e uma das mulheres frequentavam o curso de mecânica automotiva e suas aulas eram ministradas por um único professor. Entre os alunos de mecânica, percebemos desnivelamento no conhecimento da matéria, pois uns demonstravam saber muito mais sobre mecânica do que outros. Nessa sala havia computadores para os alunos e verificamos que alguns navegavam por sites alheios ao conteúdo das aulas.

O horário de término do curso era por volta de $22 \mathrm{~h} 30$ e muitos alunos e alunas moravam em outras regiões administrativas distantes e precisavam recorrer ao ônibus para retornarem a suas casas. Nessa ocasião, um aluno e o professor, que possuíam carro, ofereciam carona, pelo menos até um terminal de ônibus. 
Quanto às aulas de língua inglesa, terminavam mais cedo, e as duas mulheres da pesquisa que frequentavam esse curso, iam embora a pé, pois moravam próximo à escola, em uma região administrativa com infraestrutura urbana e segurança precárias.

Esses esforços demonstrados para estudar somados ao comportamento de compromisso frente ao curso, sugerem que os participantes da pesquisa frequentavam as aulas em busca de melhorar suas condições sociais.

Nessa perspectiva, a interpretação dos desejos contidos nas narrativas imaginadas sobre uma viagem levou em consideração a condição social, cultural e histórica dos entrevistados, bem como sua inexperiência em realizar viagens de turismo.

Após a transcrição das entrevistas, aplicamos a análise temática e selecionamos as frases de cada participante que indicavam algum tipo de desejo. A seguir, agrupamo-las em função da analogia que apresentaram em relação a determinado tipo de desejo. Interpretamos e parafraseamos cada grupo de frases a partir de pontos de semelhança relativos a um desejo, descrevendo-o, em seguida procuramos a palavra ou a expressão que melhor significasse esse desejo. Essa palavra ou essa expressão definiu a categoria desejo de ...

Essas ações resultaram em agrupamentos de frases que correspondem a 18 diferentes tipos de desejos relativos a uma viagem de turismo, conforme a tabela 4 a seguir:

Tabela 4 - Categorização dos desejos

\begin{tabular}{|c|c|c|c|c|c|}
\hline Grupo & Desejos de & Grupo & Desejos de & Grupo & Desejo de \\
\hline 1 & Mordomia & 7 & Contemplar paisagens & 13 & $\begin{array}{l}\text { Contemplar objetos } \\
\text { extraordinários }\end{array}$ \\
\hline 2 & Conforto & 8 & $\begin{array}{l}\text { Integração com a } \\
\text { natureza }\end{array}$ & 14 & Alargar os horizontes \\
\hline 3 & Descanso & 9 & Aventura & 15 & Comparar os modos de vida \\
\hline 4 & Tempo livre & 10 & Consumo & 16 & Autenticidade \\
\hline 5 & Diversão & 11 & Viajar em grupo & 17 & Desenvolvimento intelectual \\
\hline 6 & $\begin{array}{l}\text { Redução de controles } \\
\text { sociais }\end{array}$ & 12 & $\begin{array}{l}\text { Interação social face a } \\
\text { face }\end{array}$ & 18 & Mudança de status \\
\hline
\end{tabular}

Fonte: Autor

Uma vez categorizados os desejos que os jovens gostariam de ver satisfeitos em uma viagem de turismo, passamos a analisá-los, um a um, sob a perspectiva de sua relação com o turismo 
em geral e com o Turismo Social, que é uma modalidade de turismo ao alcance das pessoas que não dispõem de recursos financeiros para viajar.

Tabela 5 - Categorização dos desejos do grupo 1

\begin{tabular}{lcc}
\hline \multicolumn{1}{c}{ Frases Selecionadas $^{18}$} & Interpretação e Descrição & Categoria \\
\hline Teria um dia de princesa (D) & & \\
Seria interessante que alguém fosse me buscar em casa (R) & O grupo de frases abaixo \\
Gostaria que tivesse pessoas dedicadas a mim (D) & exprime o desejo de o jovem & não ter que adotar \\
Gostaria que tivesse pessoas para me acompanhar e explicar (D) & pessoalmente as providências & DESEJO DE \\
Alguém para cuidar de mim (R) & mais prosaicas relativas à & MORDOMIA \\
Queria que atendessem todos meus desejos (D) & realização de uma viagem, e & de que haja pessoas ao redor \\
Gostaria que tivesse um avião me esperando (E) & para antecipar e atender & \\
Uma pessoa me esperando para levar ao hotel (E) & qualquer necessidade. & \\
Gostaria que me levassem ao hotel (D) & & \\
Ficaria no melhor hotel (S) (2) & & \\
Um carro à disposição para me levar aos lugares que eu quiser & & \\
conhecer (E) & & \\
Ter pessoas para me mostrar os lugares mais interessantes (F) & & \\
\hline Fonte: Autor & &
\end{tabular}

Fonte: Autor

É conhecido o desejo de alguns viajantes de comportarem-se como um hóspede-rei; de não serem mais aquele que recebe ordens, mas as distribui; de assumirem o papel de um personagem diferente do que desempenham em seu cotidiano (KRIPPENDORF, 2001).

De acordo com Gottlieb (1982, apud URRY, 2001), o que se procura nas férias é a inversão do cotidiano, assim um turista de baixa renda procurará ser rei/rainha por um dia.

A satisfação do desejo de mordomia implica serviços de transporte, hotelaria e alimentação altamente sofisticados encontrados apenas em voos de primeira classe, hotéis cinco estrelas e serviços de transporte de luxo, disponíveis para o turismo em geral, mas fora das possibilidades do Turismo Social, que deve ter baixo custo.

Tabela 6 - Categorização dos desejos do grupo 2

Frases Selecionadas Interpretação e Descrição Categoria

Iria de avião (S)

Gostaria de um voo que tivesse direito a tudo (D)

Ficaria no melhor hotel (S) (1)

Quarto arrumadinho (E)

Lugar para dormir $(\mathrm{R})$

Boa alimentação (E)

Tivesse alimentação à vontade $(\mathrm{R})$

Ser bem acolhido (M)

Fonte: Autor

18 A identidade do participante é indicada pela inicial de seu nome colocada entre parênteses após cada frase e, quando uma frase aparece em mais de um grupo, ela apresenta o número do (s) outro (s) entre parênteses. 
O conforto esperado pelos jovens está ligado à ideia de hospitalidade. Ainda que seja uma hospitalidade comercial, ela é, geralmente, observada pelas empresas atuantes no ramo da hotelaria. Assim há preocupação por parte do anfitrião comercial em ser receptivo com os hóspedes e melhor recebê-los (LOPES; OLIVEIRA, 2013).

O Turismo Social está apto a satisfazer o desejo de conforto, porque uma de suas premissas é propiciar aos participantes o mesmo nível de conforto que o turismo em geral.

Tabela 7 - Categorização dos desejos do grupo 3

\begin{tabular}{|c|c|c|}
\hline Frases Selecionadas & Interpretação e Descrição & Categoria \\
\hline $\begin{array}{l}\text { Descansar (M) } \\
\text { Dormir (R) } \\
\text { Desestressar (M) } \\
\text { Descontrair }(M) \\
\text { Tirar o stress }(M) \\
\text { Caminhar relaxada }(\mathrm{E})(7) \\
\text { Jogar conversa fora }(\mathrm{R})\end{array}$ & $\begin{array}{l}\text { As ações listadas significam o alívio } \\
\text { das tensões, receios, aflições e } \\
\text { ansiedades típicas do cotidiano } \\
\text { moderno e expressam um desejo de } \\
\text { descanso. }\end{array}$ & $\begin{array}{l}\text { DESEJO DE } \\
\text { DESCANSO }\end{array}$ \\
\hline
\end{tabular}

Descansar é um desejo comum a uma grande parcela de turistas que almejam refazer-se dos desgostos do dia a dia, recarregar as baterias. A civilização contemporânea nos submete a tensões nervosas que geram reações corporais e até doenças como hipertensão arterial, alcoolismo e outras. Desse modo, viagens de lazer nunca foram tão necessárias (KRIPPENDORF, 2001).

O descanso é uma motivação para viajar que prevalece em pesquisas realizadas na Alemanha (KRIPPERDORF, 2001) e no Reino Unido (COOPER et al., 2007) e um dos benefícios decorrentes das práticas de qualquer modalidade de turismo.

Tabela 8 - Categorização dos desejos do grupo 4

\begin{tabular}{|c|c|c|}
\hline Frases Selecionadas & Interpretação e Descrição & Categoria \\
\hline $\begin{array}{l}\text { Conhecer, só que não com horas dadas }(\mathrm{R})(6) \\
\text { Sem me preocupar até que horas vou ficar }(\mathrm{E})(6) \\
\text { Sem se preocupar com horário }(\mathrm{E})(6) \\
\text { Contar piadas para matar o tempo }(\mathrm{R}) \\
\text { Viajar tipo passando férias, tipo lua de mel (F) (6) }\end{array}$ & $\begin{array}{l}\text { Essas frases têm relação com a } \\
\text { ausência de planejamento e de } \\
\text { disciplina em relação ao uso do } \\
\text { tempo. Elas dão a entender um } \\
\text { desejo de tempo livre. }\end{array}$ & $\begin{array}{l}\text { DESEJO DE TEMPO } \\
\text { LIVRE }\end{array}$ \\
\hline
\end{tabular}


O turismo é uma forma de utilização do tempo livre muito praticada hoje em dia. Isto é, o tempo livre permite ao indivíduo praticar o turismo, que é uma forma de ócio, uma forma de satisfazer necessidades pessoais de descanso, diversão e desenvolvimento pessoal (ABITIA, 1998).

O Turismo Social atende pessoas com insuficiência de recursos para viajar, em geral são trabalhadores ou estudantes que precisam se libertar por um tempo, o tempo de férias, das pressões das obrigações, da ordem, das regras cotidianas. Na perspectiva de Krippendorf (2001, p. 49): "a viagem é tempo livre total, a forma mais libertadora de lazer".

Tabela 9 - Categorização dos desejos do grupo 5

\begin{tabular}{lcc}
\hline \multicolumn{1}{c}{ Frases Selecionadas } & Interpretação e Descrição & Categoria \\
\hline Ter um lazer (M) & & \\
Distrair-se (M) & & \\
Divertir-se (M) & & DESEJO DE \\
Divertir-se (S) & As frases selecionadas se referem & DIVERSÃO \\
Divertir-se fazendo várias atividades (F) & a entretenimento, diversão, & ludicidade, conceitos opostos aos \\
Divertir-se com o celular (R) & de trabalho e estudo. Assim, & \\
Divertir-se com a galera (R) (11) & expressam desejo de diversão. & \\
Fazer piada com os amigos (R) & & \\
Ouvir música (M) & & \\
Passear (S) (7) & & \\
Passear (D) (7) & & \\
Então, vem a diversão: a Disney (D) & & \\
Fazer um cruzeiro (D) & & \\
Viajar (E) & &
\end{tabular}

Fonte: Autor

Para Krippendorf (2001), o turismo é uma indústria da diversão e do prazer, portanto voltada à satisfação do desejo.

O Turismo Social faz parte dessa indústria, porque é praticado utilizando a mesma rede de bens e serviços do turismo em geral, portanto é competente para satisfazer o desejo de diversão.

Tabela 10 - Categorização dos desejos do grupo 6

\begin{tabular}{|c|c|c|}
\hline Frases Selecionadas & Interpretação e Descrição & Categoria \\
\hline $\begin{array}{l}\text { Deixar a galera livre }(\mathrm{R}) \\
\text { Sem ninguém me perturbando }(\mathrm{F}) \\
\text { Sem ninguém me incomodando }(\mathrm{F}) \\
\text { Ficar na minha o tempo todo, sem me preocupar com } \\
\text { nada (F) } \\
\text { Conhecer, só que não com horas dadas (R) (4) } \\
\text { Sem me preocupar até que horas vou ficar (E) (4) } \\
\text { Sem se preocupar com horário (E) (4) } \\
\text { Viajar tipo passando férias, tipo lua de mel (F) (4) }\end{array}$ & $\begin{array}{l}\text { As expressões a seguir vinculam- } \\
\text { se à ideia de liberdade, de } \\
\text { comportamentos permissivos, de } \\
\text { ausência de padrões de } \\
\text { comportamento, de estar fora do } \\
\text { alcance da vigilância. Resumindo: } \\
\text { desejo de redução de controles } \\
\text { sociais. }\end{array}$ & $\begin{array}{c}\text { DESEJO DE } \\
\text { REDUÇÃO DE } \\
\text { CONTROLES SOCIAIS }\end{array}$ \\
\hline
\end{tabular}


A viagem é a forma mais libertadora do lazer, ela nos afasta do ambiente habitual e nos liberta da casa e do trabalho. Ainda que a organização atual do turismo não favoreça a liberdade, nem a autonomia do turista, a viagem ainda conserva uma boa dose de liberdade (KRIPPENDORF, 2001).

Os jovens entrevistados estão submetidos a vários tipos de controle social: da família, do grupo social, da escola, do trabalho, da baixa renda. O Turismo Social reduz o controle econômico e social exercido pela baixa renda.

Tabela 11 - Categorização dos desejos do grupo 7

\begin{tabular}{lrr}
\hline \multicolumn{1}{c}{ Frases Selecionadas } & Interpretação e Descrição & Categoria \\
\hline Eu achava legal a estrada, o caminho (E) & & \\
Ver as plantações do caminho (E) & & \\
Gostava mais da viagem que da chegada (E) & Os enunciados abaixo se & \\
Andando, passeando, passeando, conhecendo o lugar (E) & vinculam ao vaguear sem & DESEJO DE \\
Caminhar relaxada (E) (3) & compromisso, ao observar as & CONTEMPLAR \\
Passear (S) (5) & paisagens, os lugares, as pessoas, & PAISAGENS \\
Passear (D) (5) & tout court: desejo de contemplar & paisagens. \\
Sentar em frente a um lago (E) (8) & & \\
Sentar em frente a uma praia tranquila (E) (8) & & \\
Apreciar a paisagem (F) (8) & & \\
Tirar fotos (E) & & \\
\hline Fonte: Autor & &
\end{tabular}

O olhar do turista procura aspectos da paisagem diferentes da sua paisagem de todos os dias. Essa procura faz com que o olhar se torne mais sensível quando examina paisagens do campo e da cidade. As pessoas se conectam a esse olhar que é capturado através de fotos, filmes, cartões postais (URRY, 2001).

O deslocamento por locais diferentes do habitual é essencial ao turismo, e um de seus corolários é a mudança de paisagens, tanto no decorrer da viagem, quanto no destino. O desejo de apreciar as paisagens e registrá-las em fotos pode ser satisfeito em uma viagem de Turismo Social, porque, além de representar uma atitude típica do turista, não implica custos adicionais.

Tabela 12 - Categorização dos desejos do grupo 8

\begin{tabular}{lcc}
\hline \multicolumn{1}{c}{ Frases Selecionadas } & Interpretação e Descrição & Categoria \\
\hline Curtir a natureza $(\mathrm{M})$ & Essas proposições não dizem respeito a & \\
Conhecer florestas $(\mathrm{M})$ & observar a paisagem, mas a fazer parte dela. & \\
Conhecer praias maravilhosas $(\mathrm{R})$ & Referem-se a entrar em corpo a corpo com & DESEJO DE \\
Acampar $(\mathrm{M})(9)$ & a natureza, senti-la na pele, sentir seus & INTEGRAÇÃO COM A \\
Tomar banho de cachoeira $(\mathrm{M})(9)$ & cheiros, percebê-la com todos os sentidos. & NATUREZA \\
Mergulhar $(\mathrm{M})(9)$ & Trata-se de um desejo de integração com a & \\
Fazer passeios aquáticos $(\mathrm{M})(9)$ & natureza. & \\
\hline
\end{tabular}


(Continuação)

Andar de buggie em dunas de areia (M) (9)

Apreciar a paisagem (F) (7)

Sentar em frente a um lago (E) (7)

Sentar em frente a uma praia tranquila (E) (7)

Fonte: Autor

O entendimento da natureza como fonte de renovação do ser humano vem desde o fim do século XVII. A vida atribulada e, ao mesmo tempo, plena de facilidades típica das cidades modernas torna a natureza muito especial sob a ótica do turista, pois ele vislumbra sua integração com a natureza como um momento de ruptura com o seu cotidiano e de renovação das energias e do equilíbrio pessoal (LOBO; MORETTI, 2008).

A implementação de políticas públicas de Turismo Social implica um incremento no fluxo turístico. Assim, ela demanda avaliações dos impactos desse aumento de fluxo sobre a natureza, as localidades e as culturas, a fim de preservar a sustentabilidade dos locais visitados.

Tabela 13 - Categorização dos desejos do grupo 9

\begin{tabular}{lcc}
\hline \multicolumn{1}{c}{ Frases Selecionadas } & Interpretação e Descrição & Categoria \\
\hline $\begin{array}{l}\text { Conhecer locais que nenhuma pessoa já foi (M) (16) } \\
\text { Conhecer locais pouco visitados (M) (16) }\end{array}$ & \\
Acampar (M) (8) & As assertivas deste grupo reúnem & \\
Tomar banho de cachoeira (M) (8) & atividades cuja prática envolve & DESEJO DE \\
Mergulhar (M) (8) & riscos, incertezas, perigos, o & AVENTURA \\
Fazer passeios aquáticos (M) (8) & inédito, o inusitado. Elas & \\
Andar de buggie em dunas de areia (M) (8) & exprimem um desejo de aventura. & \\
Eu queria explorar (D) (17) & & \\
É para descobrir mesmo (D) (17) & & \\
\hline
\end{tabular}

Fonte: Autor

O Turismo de Aventura se baseia na prática de atividades que envolvem emoções e riscos controlados, ele exige o deslocamento para locais apropriados, que por vezes são de difícil acesso, o uso de técnicas e equipamentos específicos, a adoção de procedimentos de segurança e de respeito ao meio ambiente e às populações locais (LÓPEZ-RICHARD; CHINÁGLIA, 2004).

O Turismo de Aventura encontra sintonia com o Turismo Social na contribuição para a socialização (CESE, 2006), pois melhora as competências dos participantes em vencer desafios, comunicar-se com outras pessoas e trabalhar em equipe na solução de problemas (LÓPEZRICHARD; CHINÁGLIA, 2004). 
Tabela 14 - Categorização dos desejos do grupo 10

\begin{tabular}{lcc}
\hline \multicolumn{1}{c}{ Frases Selecionadas } & Interpretação e Descrição & Categoria \\
\hline Eu queria comprar, comprar, comprar (D) & & \\
Queria conhecer marcas (D) & & \\
Ir a lugares onde se gasta dinheiro (D) & Os assertos em pauta referem-se à & \\
Ir a restaurantes caros (D) & possibilidade de acesso a bens e & DESEJO DE \\
Se a gente tem dinheiro, a gente compra tudo (D) & serviços e evidenciam um campo & CONSUMO \\
Se a gente tem dinheiro, a gente realiza tudo (D) & central do comportamento e do & \\
Esbanjar bastante em passeios (M) & cultura de contemporâneo, que é a & \\
Esbanjar em diversões (M) & um desejo de consumo. & \\
Esbanjar em lugares (M) & & \\
Frequentar lugares ótimos (F) & & \\
Comprar coisas em lojas e shoppings (E) & & \\
Fazer compras no shopping (S) & & \\
Conhecer o shopping (R) & & \\
\hline
\end{tabular}

Fonte: Autor

No universo da cultura do consumo, tão presente nos dias de hoje, os bens adquiridos são fundamentais no processo de distinção das pessoas, ora são marcas de singularidade e separação, ora são elementos de pertencimento e aceitação. Os jovens mais do que outros sujeitos sociais utilizam os recursos simbólicos da cultura de consumo para construir suas identidades (ENNE, 2010).

Uma das modalidades do Turismo Social consiste em subsidiar com recursos públicos e privados as pessoas que não dispõem de dinheiro para consumir os bens e serviços vinculados à atividade turística.

Tabela 15 - Categorização dos desejos do grupo 11

\begin{tabular}{lcc}
\hline \multicolumn{1}{c}{ Frases Selecionadas } & Interpretação e Descrição & Categoria \\
\hline $\begin{array}{l}\text { Imagino que viajaria com uma galera de determinado } \\
\text { curso (R) }\end{array}$ & & \\
Ia ver se a galera animava conhecer algum lugar (R) & Essas frases evocam ideias de & DESEJO DE \\
Todos teriam que conhecer o mesmo lugar (R) & aceitação, pertencimento, & VIAJAR EM GRUPO \\
Sozinho eu não faria nada (R) & amizade, compromisso, & \\
Se divertir com a galera (R) (5) & desejo de viajar em grupo. & \\
Viajar em companhia de amigos (E) & & \\
Viajar com a namorada (M) & & \\
Viajar com um grupo de amigos $(\mathrm{M})$ & & \\
\hline
\end{tabular}

Fonte: Autor

O lazer comunitário, uma atividade de pura sociabilidade, gera tensões emocionais agradáveis e formas descomprometidas de integração social (ELIAS; DUNNING ${ }^{19}, 1992$ apud ABREU, 1995).

19 ELIAS, Norbert; DUNNING, Eric. A busca da excitação. Lisboa: Difel, 1992. 
A viagem em grupo, mais do que compatível, é uma exigência do Turismo Social, que pretende um turismo de baixo custo.

Tabela 16 - Categorização dos desejos do grupo 12

\begin{tabular}{lcc}
\hline \multicolumn{1}{c}{ Frases Selecionadas } & Interpretação e Descrição & Categoria \\
\hline Conhecer novas pessoas (M) & & \\
Conhecer novas pessoas (D) & & \\
Conhecer novas pessoas (R) & & \\
Conhecer pessoas (E) & As frases trazem ideias relativas a & encontro, diálogo, convivência, \\
Conhecer pessoas (S) & busca de proximidade com a & DESEJO DE \\
Conhecer pessoas diferentes (F) & alteridade, transformação de & DE \\
Conhecer os locais mais frequentados (F) & encontros fortuitos em amizade, & INTERAÇÃO SOCIAL \\
Jantar com pessoas (F) & ampliação da rede social & FACE A FACE \\
Conviver com outros turistas (S) & mediante contatos humanos em & \\
Conviver com moradores locais (S) & pessoa, ideias que poderiam ser & resumidas em: desejo de \\
Conviver com os que auxiliam nas viagens (S) & interação social face a face. & \\
Fazer amigos (F) & & \\
Fazer amigos no local e sair com eles (E) & & \\
Conhecer novos amigos (S) & & \\
Arrumar amizade em um lugar que você não conhece (F) & & \\
Fazer amizade durante o voo (D) & & \\
Mesmo viajando com meu namorado, eu queria fazer & & \\
amizades (D) & & \\
Queria ter amigos naquele local de viagem (D) & & \\
\hline
\end{tabular}

Fonte: Autor

Relacionamentos turísticos surgem da movimentação das pessoas que viajam e deixam seus lugares de origem para permanecerem por um tempo em lugar ou lugares novos (URRY, 2001).

Durante as férias, os turistas desejam estabelecer contatos com outras pessoas e conhecê-las, em oposição ao anonimato e à ausência de relações humanas próprias do cotidiano (KRIPPENDORF, 2001).

O turismo Social, assim como o turismo convencional, propicia oportunidades de socialização, de contato, de comunicação e de amizade entre as pessoas (CESE, 2006).

Tabela 17 - Categorização dos desejos do grupo 13

\begin{tabular}{llc}
\hline \multicolumn{1}{c}{ Frases Selecionadas } & Interpretação e Descrição & Categoria \\
\hline Conhecer os atrativos turísticos da região (R) & & \\
Conhecer lugares especiais do meu país (R) & As frases deste grupo indicam & \\
Fazer turismo pela cidade (F) & interesse na visitação de bens do & DESEJO DE \\
Conhecer um museu (R) & patrimônio histórico e cultural, e & CONTEMPLAR \\
Conhecer o Cristo Redentor (R) & outros locais famosos, o que nos & OBJETOS \\
Conhecer as pirâmides do México (D) & faz ver um desejo de contemplar & EXTRAORDINÁRIOS \\
Conhecer a torre Eiffel (S) & objetos extraordinários. & \\
Conhecer coisas novas (R) & & \\
\hline Fonte: Autor & & \\
\hline
\end{tabular}

Fonte: Autor 
Os objetos do olhar do turista precisam ser extraordinários, eles precisam situar-se em uma escala diferente da ordinária, precisam provocar sensações distintas daquelas que se obtém contemplando um objeto qualquer. Alguns desses objetos são conhecidos e atraem muitos turistas, como é o caso da torre Eiffel (URRY, 2001).

A ida até esses objetos é uma atividade típica do turismo, e é compatível com o Turismo Social, desde que não implique custos elevados.

Tabela 18 - Categorização dos desejos do grupo 14

\begin{tabular}{lcc}
\hline \multicolumn{1}{c}{ Frases Selecionadas } & Interpretação e Descrição & Categoria \\
\hline Conhecer novos lugares (E) & & \\
Conhecer novos lugares (S) & & \\
Conhecer novos lugares (D) & & DESEJO DE \\
Conhecer novos lugares (R) & As ações descritas nessas & HLARGAR OS \\
Conhecer outros lugares (M) & sentenças indicam a visita e & \\
Conhecer outros lugares (F) & explocação de lugares inéditos & para o turista e exprimem o \\
Conhecer outras regiões (M) & desejo de alargar os horizontes. & \\
Conhecer outros países (R) & & \\
Conhecer os benefícios da região (R) & & \\
Conhecer o México (D) & & \\
Conhecer o Rio de Janeiro (R) & & \\
Conhecer Fernando de Noronha (M) & & \\
Conhecer Paris (S) & & \\
Eu queria explorar (D) (9) & & \\
É para descobrir mesmo (D) (9) & & \\
\hline Fonte: Autor & &
\end{tabular}

Na Roma Imperial, a elite viajava longas distâncias em busca de prazer e cultura. Mais adiante, os peregrinos partiam para a Terra Santa. Depois foram os jovens da aristocracia europeia a correr mundo em busca de experiências e desenvolvimento intelectual. Algum tempo depois, hordas de trabalhadores se deslocavam pela Europa e Estados Unidos, gozando suas férias em locais diferentes dos do trabalho e moradia (URRY, 2001).

O desejo de o homem alargar seus horizontes é mais antigo que o Turismo. Ele está em sintonia com os benefícios esperados da prática do Turismo Social, como promover o contato do turista com outras realidades geográficas, contribuir com o desenvolvimento econômico local e impor a sustentabilidade nas destinações (CESE, 2006).

Tabela 19 - Categorização dos desejos do grupo 15

\begin{tabular}{lcc}
\hline \multicolumn{1}{c}{ Frases Selecionadas } & Interpretação e & Categoria \\
\hline Vescrição & DESEJO DE \\
Viver algum tempo em outra realidade (M) & Essas proposições & COMPARAR OS \\
Der uma experiência de vida diferente (M) & significam experimentar e & MODOS DE \\
avaliar o modo de viver & VIDA \\
\hline
\end{tabular}




\begin{tabular}{lc}
\hline (Continuação) & (Continuação) \\
Conhecer outras culturas ((M) & $\begin{array}{c}\text { dos habitantes do local } \\
\text { visitado, conhecer o } \\
\text { Conhecer o cotidiano das pessoas para ver se há diferença com meu } \\
\text { cotidiano (F) }\end{array}$ \\
$\begin{array}{l}\text { Conhecer outros meios de viver (M) } \\
\text { Conversar com os habitantes locais, eu contaria sobre as coisas do lugar } \\
\text { onde moro e eles me contariam sobre o lugar onde vivem, sua vida } \\
\text { pessoal (E) }\end{array}$ & $\begin{array}{c}\text { informações sobre o } \\
\text { próprio modo de viver. }\end{array}$ \\
Trocar conhecimentos com os habitantes locais sobre as características & $\begin{array}{c}\text { Elas indicam um desejo } \\
\text { de comparar os modos de }\end{array}$ \\
Conhecer as fundações das casas (S) & vida. \\
Adaptar-se ao modo de vida local para poder se divertir (F) & \\
Procurar locais frequentados pelos habitantes locais que me agradem (F) & \\
Passear em restaurantes e casas noturnas frequentados pelos habitantes & \\
locais (F) (16) & \\
Experimentar comidas típicas do local (E) (16) & \\
Experimentar novos alimentos (D) & \\
Compartilhar música (M) & \\
Compartilhar cultura (M) & \\
\hline
\end{tabular}

Fonte: Autor

Na visão de Urry (2001), os objetos potenciais do olhar do turista precisam focar algo extraordinário. Essa necessidade é atendida quando se examina aspectos comuns da vida social. Por exemplo, a rotina dos habitantes do local visitado.

Nos encontros interculturais ensejados pelo turismo, o olhar do viajante procura conhecer o outro, colocando em evidência as diferenças identitárias. Esse processo provoca interações e modificações em todos os atores (RICCO, s.d).

Para o Comitê Econômico Europeu - CESE, os encontros interculturais decorrentes da prática do Turismo Social contribuem para a socialização das pessoas. (CESE, 2006).

Tabela 20 - Categorização dos desejos do grupo 16

\begin{tabular}{|c|c|c|}
\hline Frases Selecionadas & Interpretação e Descrição & Categoria \\
\hline $\begin{array}{l}\text { Ter um conhecimento aprofundado do lugar }(\mathrm{R}) \\
\text { Não ficar só naquele percursinho }(\mathrm{R}) \\
\text { Para conhecer um lugar não basta ter dinheiro, ter tempo (R) } \\
\text { Passear em restaurantes e casas noturnas frequentados pelos } \\
\text { locais (F) (15) } \\
\text { Experimentar comidas típicas do local (E) (15) } \\
\text { Conhecer locais que nenhuma pessoa já foi (M) (9) } \\
\text { Conhecer locais pouco visitados, de difícil acesso (M) (9) }\end{array}$ & $\begin{array}{l}\text { As frases demonstram a } \\
\text { disposição de conhecer mais do } \\
\text { que encenações culturais } \\
\text { realizadas em espaços destinados } \\
\text { ao turismo, demonstram um } \\
\text { interesse pela vida real dos } \\
\text { habitantes e pelo cotidiano da } \\
\text { localidade visitada; manifestam } \\
\text { um desejo de autenticidade. }\end{array}$ & $\begin{array}{c}\text { DESEJO DE } \\
\text { AUTENTICI } \\
\text { DADE }\end{array}$ \\
\hline
\end{tabular}

Fonte: Autor

Ao contrário dos chamados pós-turistas, que se deliciam com a inautenticidade das encenações montadas pelos habitantes locais exclusivamente para turistas, porque sabem que a experiência turística é ensaiada e apresentada (URRY, 2001), os jovens entrevistados expressaram o desejo de conhecer coisas autênticas, um fascínio por pessoas e coisas reais. 
O desejo de entrar em contato com manifestações culturais autênticas e de conhecer o cotidiano real das pessoas do lugar visitado está entre os benefícios esperados da prática do Turismo Social, e dizem respeito a enriquecer a visão de mundo dos jovens.

Tabela 21 - Categorização dos desejos do grupo 17

\begin{tabular}{lcc}
\hline \multicolumn{1}{c}{ Frases Selecionadas } & Interpretação e Descrição & Categoria \\
\hline Eu ia pesquisar bastante (D) & & \\
Pesquisar (S) & Essas frases comunicam aquisição & DESEJO DE \\
Meu desejo é sempre aprender (D) & de conhecimento, educação, e & DESENVOLVI \\
Conhecer o porquê de cada coisa (S) & tornam patente o desejo de & MENTO \\
Eu queria explorar (D) (9) & desenvolvimento intelectual. & INTELECTUAL \\
É para descobrir mesmo (D) (9) & & \\
Não adianta nada falar de uma coisa sem saber (R) & & \\
Adquirir mais conhecimento me ajudaria bastante (S) & & \\
\hline Fonte: Autor & &
\end{tabular}

O chamado Turismo Educativo se vale de viagens de turismo para ministrar conhecimentos e disciplinas do currículo em espaços fora da escola: campo, sítios arqueológicos, cidades históricas, ecossistemas (OLIVEIRA, 2006; PERINOTTO, 2008).

O Turismo Social, mediante subsídios financeiros, permite o acesso de jovens de baixa renda aos benefícios decorrentes da prática do Turismo Educativo e, assim, reduz o déficit educacional existente entre eles e os jovens abastados que recebem uma educação extraclasse, de custo elevado, desde o início do processo de escolarização.

Tabela 22- Categorização dos desejos do grupo 18

\begin{tabular}{lcc}
\hline & Interpretação e Descrição & Categoria \\
\hline & Esses períodos se relacionam com & DESEJO DE \\
$\begin{array}{l}\text { Ter histórias para contar na volta }(\mathrm{M}) \\
\text { Mostrar lugares (F) }\end{array}$ & a aquisição de conhecimentos & Murante a viagem e significam um \\
& desejo de mudança de status. & STATUS DE \\
\hline
\end{tabular}

Fonte: Autor

A viagem de turismo pode proporcionar experiências ao turista que implicam uma mudança, para melhor, em seu status social, quando, ao retornar da viagem, reintegra-se a seu grupo social (URRY, 2001).

Essa mudança de status, que pode ser conquistada em uma viagem, independe desta ser realizada no âmbito do turismo convencional ou do Turismo Social, porque a diferença entre esses dois tipos de turismo diz respeito ao orçamento, não à qualidade das experiências inerentes a uma viagem. 


\section{CONSIDERAÇÕES FINAIS}

O referencial empírico dessa dissertação prendeu-se ao levantamento de desejos dos jovens do PRONATEC, no Distrito Federal, relativos a uma viagem imaginada. Evidenciou que esses desejos descritos representam a esfera do turismo e, portanto, podem ser satisfeitos durante uma viagem real. Desse modo, constatamos a pertinência de explorar o imaginário dos jovens de baixa renda residentes no Distrito Federal, para descrever desejos que podem estimular sua motivação para participar de políticas públicas voltadas para a prática do turismo.

Como pudemos observar, à exceção dos desejos de conforto e mordomia, que entendemos representar a segurança requerida pelos jovens para enfrentar os riscos associados à consecução dos outros desejos, os desejos descritos relacionaram-se com atividades lúdicas, culturais e de sociabilidade, naturalmente relacionadas à educação e ao lazer e normalmente proporcionadas por uma viagem de turismo real.

Explicando melhor, a comparação dos desejos dos jovens entrevistados com as motivações de viagem na Alemanha e no Reino Unido mostrou que, apesar das grandes diferenças culturais, sociais e econômicas entre os jovens de baixa renda do Distrito Federal e os turistas regulares daqueles países, a lista das imagens contidas no imaginário dos jovens entrevistados não é muito distante das listas de motivações de viagem dos turistas europeus. Salvo o desejo de consumo, expresso como: comprar, comprar, comprar; conhecer marcas; fazer compras no shopping; o desejo de mordomia; e o de mudança de status, os demais aparecem nas três listas; de modo agregado na lista britânica.

No entanto, enquanto nos levantamentos europeus a fuga e o descanso prevalecem como motivação para viajar, ficou patente, durante as entrevistas e na análise dos dados, a prevalência do desejo de conhecimento entre os jovens entrevistados: conhecer novas pessoas; conhecer novos lugares; conhecer outras culturas; conhecer o cotidiano de outras pessoas para ver se há diferenças com meu cotidiano; conhecer um museu; meu desejo é sempre aprender; adquirir mais conhecimento me ajudaria bastante, são expressões representativas do teor das entrevistas. 
O desejo de lazer também é bastante presente nas entrevistas, em expressões como: divertir-se com a galera, tomar banho de cachoeira; curtir a natureza; apreciar a paisagem; passear; ter um lazer; então vem a diversão: a Disney; sem me preocupar com horário; jogar conversa fora.

Logo, chega-se à conclusão que todos os desejos descritos neste trabalho são capazes de motivar jovens em situação próxima da dos entrevistados a participarem de políticas públicas de turismo como via de acesso à educação e lazer, porque todos eles podem ser satisfeitos durante uma viagem de turismo. Mesmo desejos aparentemente incompatíveis com esse objetivo, como os de descanso e tempo livre, quando considerados no âmbito da viagem turística, mostram-se compatíveis, porque o descanso e o tempo livre se darão fora do contexto dos relacionamentos cotidianos do jovem, em outra cidade, em outro contexto cultural, o que implica a consecução de outros desejos descritos, como conhecer pessoas, conhecer lugares, fazer amizades, ter os controles sociais reduzidos, etc.

Assim, uma vez verificado que os jovens têm desejos que podem ser satisfeitos em uma viagem turística e que a satisfação desses desejos, no âmbito da viagem, se dá paralelamente à fruição do direito à educação e ao lazer, confirma-se que o Turismo é uma via de acesso à aquisição de educação e lazer. A competência da viagem de turismo como via de acesso à educação, há muito tempo, é conhecida pelas escolas, que se utilizam do Turismo Educativo em favor de seus alunos.

Sem dúvida, educação e lazer podem ser adquiridos por outras formas que não a prática do turismo, mas sua aquisição durante uma viagem traz vantagens adicionais para os jovens. $\mathrm{Na}$ viagem, eles vivem por algum tempo longe de sua realidade e de seu cotidiano cultural, familiar, social, relacional e desfrutam de um relaxamento dos processos de controle social. Esse distanciamento autoriza e exige maior autonomia e favorece a experimentação de novas formas de comportamento. Exercício muito útil para os jovens que estão construindo suas identidades.

Essas experiências, somadas ao conhecimento de novos lugares, novas pessoas, novas culturas constituem matéria-prima para a criação e a revisão de estilos de vida, de planos de vida, e da autoidentidade. Já foi mencionado neste trabalho que a criação imaginária depende da qualidade e da quantidade de experiências vividas pelo indivíduo, porque ela se apoia em elementos tomados da realidade e presentes na experiência anterior.

A quantidade e a qualidade da matéria-prima usada na construção da autoidentidade é extremamente relevante para os jovens porque, nos tempos atuais, os papéis sociais não são 
mais determinados pela tradição, nem pelas relações sociais, mas estão em branco, o que exige a criação da identidade mediante um processo reflexivo, ou seja, a criação de uma autoidentidade. Além disso, a aceleração das mudanças sociais e um futuro cada vez mais incerto e indeterminável os obriga a revisá-la e recriá-la constantemente. Desse modo, um indivíduo com mais conhecimentos e mais experiências tem condições de criar estilos de vida, planos de vida e autoidentidades mais complexas, mais flexíveis, mais adaptáveis às constantes mudanças e exigências da sociedade, o que implica uma vantagem competitiva para sua integração social.

Nesse sentido, podemos afirmar que a viagem acrescenta experiência e conhecimento, e proporciona lazer ao indivíduo e, portanto, quem não viaja tem um déficit de experiência e conhecimento e de lazer em relação a quem viaja. Então, se um número expressivo de jovens tem esse déficit porque não dispõe dos recursos financeiros para viajar, fica evidente a necessidade de formulação e implementação de uma política pública para o corrigir.

Na formulação dessa política, é obrigatório considerar que educação e lazer são direitos sociais garantidos pela Constituição Federal e demandam uma ação do Estado para se efetivarem. Também cabe considerar que o sistema de produção em vigor gera os indivíduos sem poder aquisitivo para viajar, e que é papel do Estado distribuir mais equitativamente os resultados da produção econômica. Essas premissas nos conduzem diretamente para o Turismo Social, como uma opção de política pública competente para reduzir o déficit de educação e de lazer que afeta os jovens de baixa renda.

O Turismo Social tem por objetivo proporcionar viagens turísticas a quem tem algum impedimento para viajar: idosos, pessoas com deficiência, pessoas que não dispõem de dinheiro. Quando se trata de impedimento de ordem financeira, a viagem é viabilizada mediante subsídios financeiros públicos e privados. Esse tipo de Turismo é bastante difundido na Europa, e no Brasil ainda é incipiente.

Concluindo este trabalho, manifestamos nossa visão de que subsidiar viagens de turismo a jovens que não dispõem de recursos financeiros para viajar significa reduzir o déficit de experiência e conhecimento e de lazer que estes apresentam em relação àqueles que praticam viagens de turismo, significa também elevar seu capital cultural e proporcionar melhores condições para que possam ser, cada vez mais, senhores de seu destino. 


\section{REFERÊNCIAS}

ABITIA, Sergio Rodríguez. Dimension del turismo dentro marco del tempo libre. In: MOLINA, Sergio et al. (Orgs.). Reflexiones sobre el ocio y el tempo libre. México: Trillas, 1998, p. 34-42.

ABREU, Paula. Turismo Internacional de Jovens. Revista Crítica de Ciências Sociais. N. 43, out. 1995.

ATKINSON, Robert. The life story interview. (Qualitative Research Methods, v. 44). Thousand Oaks: Sage, 1998.

BARDIN, Laurence. Análise do discurso. Trad. Luís Antero Reto; Augusto Pinheiro. Lisboa: Edições 70, 2002.

BRASIL. Constituição da República Federativa do Brasil. 18. ed. Brasília: Câmara dos Deputados, Coordenação de Publicações, 1988.

. Ministério do Turismo. Programas e ações: Viaja Mais Melhor Idade. Brasília: Mtur, 2007. Disponível em: http:/www.turismo.gov.br/turismo/programas acoes /promocao _comercializacao/viajamais_melhoridade.html. Acesso em: out. 2013.

. Lei $\mathrm{N}^{\mathrm{o}}$ 11.771, de setembro de 2008a. Dispõe sobre a Política Nacional de Turismo, define as atribuições do Governo Federal no planejamento, desenvolvimento e estímulo ao setor turístico; revoga a Lei no 6.505 , de 13 de dezembro de 1977, o Decreto-Lei no 2.294, de 21 de novembro de 1986, e dispositivos da Lei no 8.181, de 28 de março de 1991; e dá outras providências. Diário Oficial da União, Brasília, DF, 18 de set. 2008, Seção 1, p. 1.

Ministério do Turismo. Turismo cultural: orientações básicas. / Ministério do Turismo, Secretaria Nacional de Políticas de Turismo, Departamento de Estruturação, Articulação e Ordenamento Turístico, Coordenação Geral de Segmentação. 2. ed., Brasília: Ministério do Turismo, 2008b. 60 p. Disponível em: Æwww.turismo.gov.br/.../downloads publicacoes/Livro_Cultural.pdf>. Acesso em: abr. 2014.

. Ministério do Turismo. Notícias. Viaja Mais Jovem chega a Brasília. Brasília: Mtur.

2009. Disponível em: £http://www.turismo.gov.br/turismo/noticias/todas noticias /200911103.htmp. Acesso em out. 2013.

. IBGE - Resultados do Universo do Censo Demográfico 2010. Brasília: 2010a. Disponível em: fftp://ftp.ibge.gov.br/Censos/Censo Demografico 2010/Resultados do Uni verso/tabelas_pdf/tab1.pdfp. Acesso em: ago. 2014.

. Ministério da Educação. Conselho Nacional de Educação Câmara de Educação Básica. Resolução CNE/CEB 4/2010. Define Diretrizes Curriculares Nacionais Gerais para a Educação Básica. 2010b. Disponível em: Łhttp://portal.mec.gov.br/dmdocuments /rceb004 10.pdf?. Acesso em ago. 2014. 
. Ministério do Turismo. Notícias. Férias a preço baixo para o trabalhador brasileiro. Brasília: Mtur, 2010c. Disponível em: Łhttp://www.turismo.gov.br/turismo/noti cias/todas notícias/20100528-8.html>. Acesso em out. 2013.

- Secretária de Assuntos Estratégicos da Presidência da República. Brasil em Desenvolvimento: Estado, planejamento e políticas públicas / Instituto de Pesquisa Econômica Aplicada. Instituições Participativas e Políticas Públicas no Brasil: Características e Evolução nas Últimas Décadas, Brasília: Ipea, 2010d, 270 p. 3 v. Disponível em: http://www.ipea.gov.br/participacao/estudos-do-ipea/interfacessocios estatais2. Acesso em out. 2013.

. Lei 12.513, de outubro de 2011. Institui o Programa Nacional de Acesso ao Ensino Técnico e Emprego (PRONATEC); altera as Leis no 7.998 , de 11 de janeiro de 1990, que regula o Programa do Seguro-Desemprego, o Abono Salarial e institui o Fundo de Amparo ao Trabalhador (FAT), nº 8.212 , de 24 de julho de 1991, que dispõe sobre a organização da Seguridade Social e institui Plano de Custeio, no 10.260, de 12 de julho de 2001, que dispõe sobre o Fundo de Financiamento ao Estudante do Ensino Superior, e no 11.129 , de 30 de junho de 2005, que institui o Programa Nacional de Inclusão de Jovens (ProJovem); e dá outras providências. Diário Oficial da União, Brasília, DF, 27 de out. 2011.

. Ministério do Turismo/FIPE - Fundação Instituto de Pesquisas Econômicas. Caracterização e Dimensionamento do Turismo Doméstico no Brasil - 2010/2011. Brasília: Motor, 2012a. Disponível em: http://www.dadosefatos.turismo.gov.br/export/sites/default/da dosefatos/demanda turistica/domestica/downloads_domestica_- 2012Relatorio Executivo n ov.pdf Acesso em: out. 2013.

Secretária de Assuntos Estratégicos da Presidência da República. Vozes da Classe Média: É ouvindo a população que se constroem políticas públicas adequadas. Caderno Vozes da Classe Média, v. 1. Brasília: SAE, 2012b. Disponível em: http://www.liberdadedeexpressao.inf.br/clientes/sae/cartilha-projeto.pdf. Acesso em: jan. 2013.

Lei $n^{\circ} 12.852$, em agosto de 2013. Institui o Estatuto da Juventude e dispõe sobre os direitos dos jovens, os princípios e diretrizes das políticas públicas de juventude e o Sistema Nacional de Juventude - SINAJUVE. Brasília, 2013a.

. Ministério do Turismo. Portaria $n^{0} 228$, de 2 de setembro de 2013. Brasília: Mtur. 2013b. Disponível em: http://www.turismo.gov.br/turismo/legislacao/portarias /2013 0904. html. Acesso em: out. 2013.

IBGE/Diretoria de Pesquisas, Coordenação de População e Indicadores Sociais. Gerência de Estudos e Análises da Dinâmica Demográfica. Projeção da população do Brasil por sexo e idade para o período de 2000-2060. Atualização, 2013c. Disponível em: http://ww w.ibge.gov.br/home/estatistica/população/projeção_da_população/2013/default_tab.shtm. Acesso em: jul. 2015.

. IBGE. Síntese de Indicadores Sociais: uma análise das condições de vida da população brasileira. Estudos \& Pesquisa: Informações demográficas e socioeconômica, 34. Rio de Janeiro, 2014. 
Ministério do Turismo. Publicações: Turismo Acessível. Brasília: Mtur, [201-]. Disponível em: http://www.turismo.gov.br/turismo/o ministerio/publicacoes/cadernos publicacoes/17turismo_acessivel.html. Acesso em: out. 2013.

CAMARGO, João Paulo. Por uma educação turística: um conceito em construção. Dissertação de Mestrado. Programa de Pós-Graduação em Educação. Universidade Estadual de Ponta Grossa: Ponta Grossa, 2005.

CARREIRO, Eduardo Augusto. Ecoturismo: Influências na Educação Física. Dissertação de Mestrado. Instituto de Biociências, UNESP: Rio Claro, 2003.

CESE. Parecer do Comité Económico e Social Europeu sobre o «Turismo Social na Europa» (2006/C 318/12). Em 19 de Janeiro de 2006, o Comité Económico e Social Europeu decidiu, nos termos do artigo $29^{\circ}$ do Regimento, elaborar parecer sobre: "Turismo Social na Europa». Jornal Oficial da União Europeia de 23.12.2006, p. C 318/67. Disponível em: http://eurlex.europa.eu/LexUriServ/LexUriServ.do?uri=OJ:C:2006:318:0067 0077:PT:PDF. Acesso em: nov. 2013.

CINTRA, Glaucia Aparecida Rosa. Análise do Turismo no Sudoeste Paulista: Os Casos de Presidente Epitácio e Rosana. Tese de Doutorado. Instituto de Geociências e Ciências Exatas, UNESP, Rio Claro, 2010.

COOPER, Chris et al. Turismo, Princípios e Prática. 3. ed. Tradução de Alexandre Salvaterra. Porto Alegre: Bookman, 2007.

COSTA, Ana Paula Bezerra; PAIVA, Maria do Socorro Diógenes; FILGUEIRA, João Maria. A inserção da Educação Ambiental na Prática Pedagógica: uma análise segundo a visão dos alunos dos Cursos Técnicos integrados do Cefet-Rn. HOLOS, Ano 22, dezembro 2006.

CRESWELL, John W. Projeto de Pesquisa: Métodos qualitativos, quantitativos e misto. 3. ed. Porto Alegre: Artmed, 2010.

CUNHA, Licíno. Economia e Política do Turismo. Alfragide: McGraw-Hill, 1997.

DAGNINO, Evelina. ¿Sociedade civil, participação e cidadania: de que estamos falando? In: MATO, Daniel (Org.) Políticas de ciudadanía y sociedad civil en tiempos de globalización. Caracas: FACES, Universidad Central de Venezuela, 2004, p. 95-110.

DAYRELL, Juarez; CARRANO, Paulo. Juventude e ensino médio: quem é este aluno que chega à escola. In: DAYRELL, Juarez; CARRANO, Paulo; MAIA, Carla Linhares (Org.). Juventude e ensino médio: diálogos, sujeitos, currículos. Belo Horizonte: Editora UFMG, 2014, p.102-133.

DENZIN, Norman; LINCOLN, Yvona S. Methods of collecting and analysing empirical materials. In: . (Orgs.) Collecting and interpreting qualitative materials. Thousand Oaks: Sage, $\overline{1998, \text { p. } 35-46 .}$

DESLAURIERS, Jean-Pierre; KÉRISIT, Michèle. O delineamento de pesquisa qualitativa. In: POUPART, Jean et al. (Org.). A pesquisa qualitativa: enfoques epistemológicos e metodológicos. Petrópolis: Vozes, 2008. p. 127-153. 
DURAND, Gilbert. Campos do Imaginário. Tradução Maria João Batalha Reis. Lisboa: Instituto Piaget, 1996.

. As Estruturas Antropológicas do Imaginário: Introdução à Arquetipologia Geral. Tradução Hélder Godinho. São Paulo: Martins Fontes, 1997.

O Imaginário. 5. ed. Tradução René Eve Levié. São Paulo: Difel, 2011.

ENNE, Ana Lucia. Juventude como o espirito do tempo, faixa etária e estilo de vida: processos constitutivos de uma categoria-chave da modernidade. Comunicação, Mídia e Consumo. v. 7 , n.20, p. 13-35, nov. 2010.

FARIA, Nathalie Danif Moreira. Curso de educação patrimonial profissionalizante: Instrumento de inserção social de jovens de 14 a 18 anos moradores da cidade de Sabará. Dissertação de mestrado. Centro de Excelência em Turismo. UNB, Brasília, 2008.

FREINET, Elise. O Itinerário de Célestin Freinet: a livre expressão na pedagogia Freinet. Rio de Janeiro: Francisco Alves Ed., 1979.

FREIRE, Paulo; FREIRE, Ana Maria Araújo (Org.). Pedagogia dos sonhos possíveis. São Paulo: Editora UNESP, 2001.

GIBBS, Graham. Análise dos dados qualitativos. Tradução de Roberto Cataldo Costa. Porto Alegre: ArtMed, 2009.

GIDDENS, Anthony. Modernidade e Identidade. Tradução Plínio Dentzien. Rio de Janeiro: Zahar, 2002.

GOELDNER, Charles R.; RITCHIE, J. R. Brent; MCINTOSH, Robert W. Turismo, princípios, práticas e filosofias. 8. ed. Tradução de Roberto Cataldo Costa. Porto Alegre: Bookman, 2002.

JOVCHELOVITH, Sandra; BAUER, Martin W. Entrevista Narrativa. In: BAUER, Martin W.; GASKELL, George (Orgs.). Pesquisa Qualitativa com Texto, Imagem e Som: um manual prático. Tradução de Pedrinho A. Guareschi. Rio de Janeiro: Vozes, 2002, p. 90 - 113.

KLEIN, Fernando Machado et al., Educação Ambiental e o Ecoturismo na Serra da Bodoquena em Mato Grosso do Sul. Soc. \& Nat., Uberlândia, ano 23 n. 2, p. 311-321, maio/ago. 2011.

KRIPPENDORF, Jost. Sociologia do Turismo: Para uma nova compreensão do lazer e das viagens. 2. ed. Tradução de Contextos Traduções. São Paulo: Aleph, 2001.

KOTTLER, Philip. Administração do Marketing. 10. ed. São Paulo: Prentice Hall, 2000.

LAPLANTINE, François; TRINDADE, Liana. O que é o Imaginário. Coleção Primeiros Passos. São Paulo: Brasiliense, 1997.

LECCARDI, Carmen. Por um significado do futuro: mudança social, jovens e tempo. Tempo Social, v. 17, n. 2, p. 35-57, nov. 2005.

LEGROS, Patrick et al. Sociologia do imaginário. 2. ed. Tradução de Eduardo Portanova Barros. Porto Alegre: Editora Sulina, 2014. 
LOBO, Heros Augusto Santos; MORETTI, Edvaldo Cesar. Ecoturismo: As Práticas na Natureza e a Natureza das práticas de Bonito, MS. Revista Brasileira de Pesquisa em Turismo. v. 2, n. 1, p. 43-71, mar. 2008.

LÓPES, Anderson Soares; OLIVEIRA, Nizamar. Hospitalidade e trocas contemporâneas na hotelaria: um estudo de caso do Quality Suítes Vila Olímpia. TURYDES Revista de Investigación em Turismo y Desarollo Local. v. 6, n. 14, jun., 2013. Disponível em: www.eumed.net/net/turydes/. Acesso em: mai. 2015.

LÓPEZ-RICHARD, Victor; CHINÁGLIA, Clever Ricardo. Turismo de Aventura: conceitos e paradigmas fundamentais. Turismo em Análise. v. 15, n. 2, p. 199-215, nov. 2004.

MARTINS FILHO, Ives Gandra da Silva. Os Direitos Fundamentais e os Direitos Sociais na Constituição d e 1988 e sua defesa. In: BRASIL. Presidência da República. Casa Civil. Subchefia de Assuntos Jurídicos. Revista Jurídica Virtual. Brasília, vol. 1, n. 4, agosto 1999. Disponível em: Łhttp://www.planalto.gov.br/ccivil 03/revista/Rev 04/direitos funda mentais.htmp. Acesso em: abr. 2014.

MINNAERT, L.; MAITLAND, R.; MILLER, G. Tourism and Social Policy: The Value of Social Tourism. Annals of Tourism Research, v. 36, n. 2, p. 316-334, 2009.

MORAIS, Carlos Blanco (Coord.) Guia de avaliação de impacto normativo. Coimbra: Almedina, 2010.

MORENO, José Carlos de Almeida; SILVA, Luciene Ferreira da. Lazer, educação e políticas públicas em países emergentes: reflexões sobre o caso brasileiro. Revista Acolhendo a Alfabetização nos Países de Língua portuguesa. São Paulo, ano 4, n. 7, 2009. Disponível em: $<$ http://www.revistas. usp.br/reaa. $>$

MORIN, Edgar. Os Setes Saberes necessários à Educação do Futuro. 9. ed. São Paulo: Cortez UNESCO, 2004.

NORTE, Angela Lopes; NEVES, Antonio Mauricio Castanheira. Mobilidade Internacional e Intercâmbio em Educação Superior: o CEFER/RJ e os programas de intercâmbio Internacional. Publit Soluções Editoriais. p. 12, 11/2009. Disponível em: <http://site. ebrary.com.id/10352740?ppg=12. Acesso em: ago. 2014.

OITS. Organisation Internationale du Tourisme Social. 2013a. Disponível em:http://www.bitsint.org/en/index.php?menu=1\&submenu=2. Acesso em: out. 2013.

. Organisation Internationale $\mathrm{du}$ Tourisme Social. 2013b. Disponível em: http://www.bits-int.org/fr/index.php?menu=1\&submenu=2. Acesso em: nov. 2013.

. Organisation Internationale du Tourisme Social. Concepts et définitions. 2013c. Disponível em: http://www.bits-int.org/fr/. Acesso em: out. 2013.

OLIVEIRA, Christian Dennys Monteiro. Do Estudo do Meio ao Turismo Geoeducativo: Renovando as Práticas Pedagógicas em Geografia. Boletim Goiano de Geografia v. 26, n. 1, p. 31-47, 2006.

OMT. O Código Mundial de Ética do Turismo, 1999. Disponível em: http://ethics. unwto.org/\$ites/all/files/docpdf/portugal.pdf. Acesso em: ago. 2014. 
ONU. Declaração Universal dos Direitos Humanos. Adotada e proclamada pela resolução 217 A (III) da Assembleia Geral das Nações Unidas em 10 de dezembro de 1948. Disponível em: $<$ http://www.onu.org.br/img/2014/09/DUDH.pdf $>$ Acesso em abr. 2014.

PAIVA, Ana Maria Severiano. O município de Armação dos Búzios e a Educação: A Escola Pública Municipal na Aldeia de Pescadores que se tornou Município e Polo Internacional de Turismo. Programa de Pós-Graduação em Educação da Universidade Federal Fluminense: Niterói, 2004.

PERINOTTO, André R. C. Turismo pedagógico: uma ferramenta para educação ambiental. Caderno Virtual de Turismo, v. 8, n. 1, p. 100-103, 2008. Disponível em: Erro! A referência de hyperlink não é válida. Acesso em: ago. 2014.

POCHMANN, Marcio. A batalha pelo primeiro emprego: a situação atual e as perspectivas do jovem no mercado de trabalho brasileiro. 2. ed. São Paulo: Publisher Brasil, 2007.

Nova classe média? O trabalho na base da pirâmide social brasileira. São Paulo: Bomtempo, 2012.

RICCO, Adriana Sartório. O turismo como fenômeno social e antropológico. [201-]. Disponível em: http://www.revistas.es.estacio.br/index.php/destarte/article/download/8/6. Acesso em: maio de 2015.

SAES, Silvia Faustino de Assis. Percepção e imaginação. São Paulo: Martins Fontes, 2010.

SALGADO, Manuel; MARTINS José Alexandre. Um Sistema de Educação e Formação em Turismo: Requisito para o Desenvolvimento Turístico. Egitania Sciências, n.1, p. 121-131, $11 / 2007$.

SARTRE, Jean Paul. A Imaginação. 7. ed. Tradução de Luiz Roberto S. Fontes. São Paulo: Difel, 1985.

. O Imaginário. São Paulo: Ática, 1996.

SATO, Cristina Sayuri. Parque Nacional da Serra do Cipó: percepção ambiental e estabelecimento de áreas para a educação. Dissertação de Mestrado. Instituto de Biociência da Universidade de São Paulo, 2007.

SILVA, Guadalupe Romero. Honduras e os caminhos para o desenvolvimento sustentável: turismo e educação ambiental. Dissertação de Mestrado. Centro de Desenvolvimento Sustentável da Universidade de Brasília: Brasília, 2006.

SOARES, Alexandre B. (Org.). Juventude e elos com o mundo do trabalho: retratos e desafios. São Paulo: Cortez, 2010.

SOUZA, Amaury de; LAMOUNIER, Bolívar. A classe média brasileira: ambições, valores e projetos de sociedade. Rio de Janeiro: Elsevier; Brasília: CNI, 2010.

SOUZA, José. (Colaboradores: ARENATI, Amaury et al.). Os batalhadores Brasileiros: Nova classe média ou nova classe trabalhadora? BELO Horizonte: Ed. EFMG Humanitas, 2010. 
SOUZA, Sandra Aparecida Paula. Pressupostos para a Educação Turística em Municípios: uma alternativa para o planejamento do turismo com base local no Município de Bituruna PR. Dissertação de Mestrado. Programa de Pós-Graduação em Turismo e Hotelaria da Universidade do Vale do Itajaí. Balneário de Camburiú, 2008.

TASCHNER, Gisela. Comunicação, Sociedade e Imaginários do Consumo. Comunicação Mídia e Consumo São Paulo, v. 7, n. 20, p. 37-57, nov., 2010.

TAHARA, Alexander Klein; DIAS, Viviane Kawano; SCHWARTZ, Gisele Maria. A Aventura e o Lazer como Coadjuvantes do Processo de Educação Ambiental. Pensar a Prática v. 9, n. 1, p. 1-12, Jan./Jun. 2006.

TOMELIN, Carlos Alberto. Gerenciamento da cadeia de suprimentos e relacionamento nas agências de viagens. In: BENI, Mário Carlos (Org.) Turismo: planejamento estratégico e capacidade de gestão - desenvolvimento regional, rede de produção e clusters. Barueri: Manole, 2012.

URRY, John. O olhar do turista: Lazer e viagens nas sociedades contemporâneas. 3. ed. Tradução de Carlos E. M de Moura. São Paulo: Studio Nobel, SESC, 2001.

VELASQUEZ, Guilherme Garcia Diretrizes Curriculares Nacionais para o Curso de Turismo: Análise de dois Projetos Políticos Pedagógicos. Dissertação de Mestrado. Programa de PósGraduação em Educação. Universidade Estadual Paulista-Júlio de Mesquita Filho-UNESP: Marília, 2009.

VIGOTSKI, Lev Semionovich. Imaginação e criação na infância: ensaio psicológico - livro para professores. Tradução Zoia Prestes. São Paulo: Ática, 2009. 


\section{APÊNDICE A}

\section{ESTIMATIVA DO NÚMERO DE JOVENS QUE NÃO VIAJARAM EM 2013 POR FALTA DE DINHEIRO}

Para efetuar esta estimativa, levamos em conta que o IBGE projetou a população brasileira para 2013 em 201 milhões de pessoas, sendo 51,7 milhões com idade entre 15 e 29 anos (BRASIL, 2013c). Outro estudo do IBGE informa que, em 2013, no Brasil, haviam 68,3 milhões de arranjos familiares (BRASIL, 2014, Tabela 6.1). Portanto, podemos dizer que cada arranjo familiar continha aproximadamente 3 pessoas.

Também levamos em conta que o rendimento familiar per capita expresso em salários mínimos - SMs, em 2013, apresentava a seguinte distribuição (BRASIL, 2014, Tabela 5.1):

\begin{tabular}{|c|c|c|c|c|}
\hline \multicolumn{5}{|c|}{$\begin{array}{c}\text { Distribuição percentual, de arranjos familiares residentes em domicílio particular, por classes de } \\
\text { rendimento mensal familiar per capita (salário mínimo) (\%) no Brasil em 2013 }\end{array}$} \\
\hline 0 a 0,25 SMs & 0,25 a 0,5 SMs & 0,5 a 1 SMs & 1 a 2 SMs & Mais de 2 SMs \\
\hline $6,4 \%$ & $13,7 \%$ & $27,4 \%$ & $26,2 \%$ & $26,3 \%$ \\
\hline
\end{tabular}

Desse modo, como cada arranjo familiar era composto por 3 pessoas, podemos estimar que o rendimento familiar, por arranjo familiar, em 2013, apresentava a seguinte distribuição:

\begin{tabular}{|c|c|c|c|c|}
\hline \multicolumn{5}{|c|}{$\begin{array}{c}\text { Estimativa de distribuição percentual, de arranjos familiares residentes em domicílio particular por } \\
\text { classes de rendimento mensal, familiar (salário mínimo) (\%) no B rasil em 2013 }\end{array}$} \\
\hline 0 a 0,75 SMs & 0,75 a 1,5 SMs & 1,5 a 3 SMs & 3 a 6 SMs & Mais de 6 SMs \\
\hline $6,4 \%$ & $13,7 \%$ & $27,4 \%$ & $26,2 \%$ & $26,3 \%$ \\
\hline
\end{tabular}

Efetuando a interpolação indicada abaixo, podemos determinar o percentual correspondente à faixa de rendimento compreendida entre 3 e 4 SMs:

$(4-3) /(6-3)=0,33 \cdot 26,2 \%=8,7 \%$

Com essa informação, podemos estimar o percentual de arranjos familiares com renda mensal entre 0 e 4 SMs, em 2013:

$6,4 \%+13,7 \%+27,4 \%+8,7 \%=56,2 \%$

Assumindo o pressuposto de que todos os arranjos familiares contêm o mesmo número de pessoas e o mesmo percentual de jovens entre 15 e 29 anos independentemente da faixa de renda, e sabendo que o número total de jovens dessa idade projetados para a população 
brasileira em 2013 foi de 51,7 milhões, podemos estimar que, em 2013, 56,2\% dos jovens, ou seja, 29 milhões de jovens entre 15 e 29 anos pertenciam a arranjos familiares com renda entre 0 e 4 SMs.

Assim, para estimar o número de jovens que não viajaram por falta de dinheiro em 2013, assumimos o pressuposto de que os resultados obtidos em pesquisa realizada pela FIPE em 2011, que indicaram que em 60,8\% dos domicílios com renda entre 0 e 4 SMs sequer uma pessoa viajou, e que $53,7 \%$ dessas pessoas declararam não ter viajado por falta de dinheiro, são aplicáveis a arranjos familiares residentes em domicílio particular com renda familiar entre 0 e 4 SMs, em 2013.

Desse modo, temos que:

$60,8 \%$ de 29,0 milhões $=17,6$ milhões; e

$53,7 \%$ de 17,6 milhões $=9,4$ milhões

Assim estimamos que, em 2013, 17,6 milhões de jovens de 15 a 29 anos pertencentes a arranjos familiares com renda entre 0 e 4 SMs não viajaram por diversos motivos, sendo que, desse total, 9,4 milhões deixaram de viajar por não disporem de recursos financeiros. 


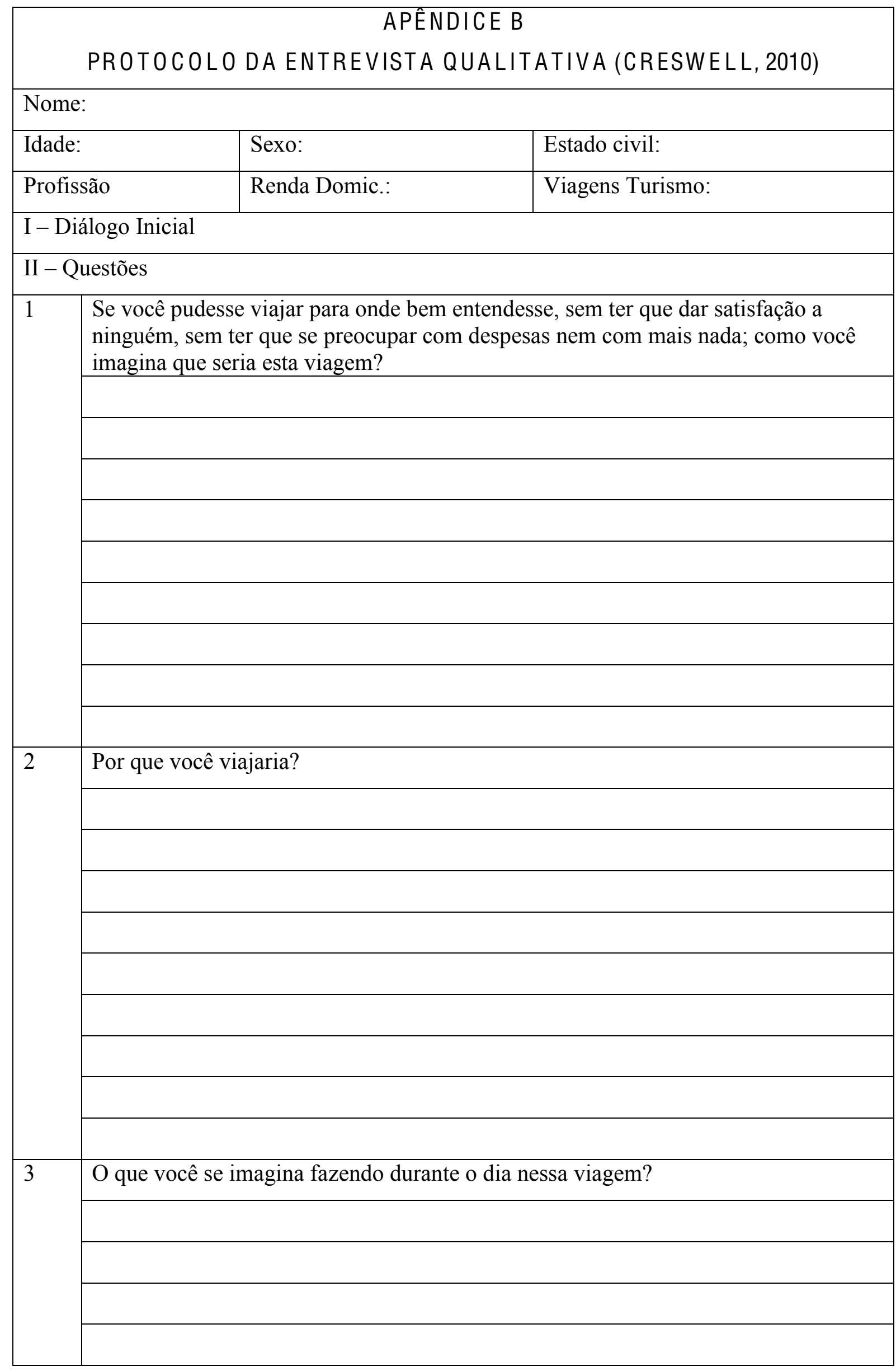




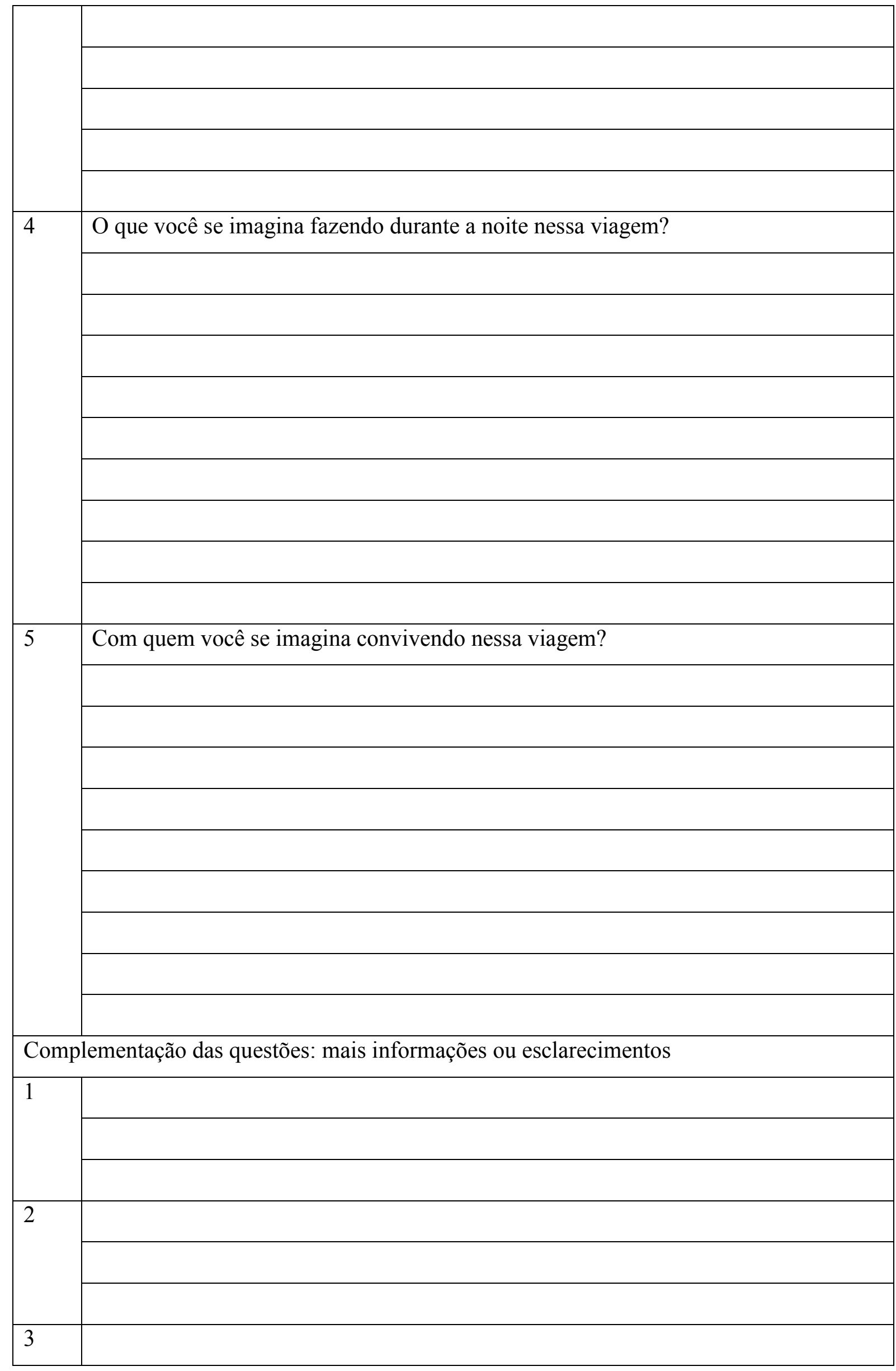




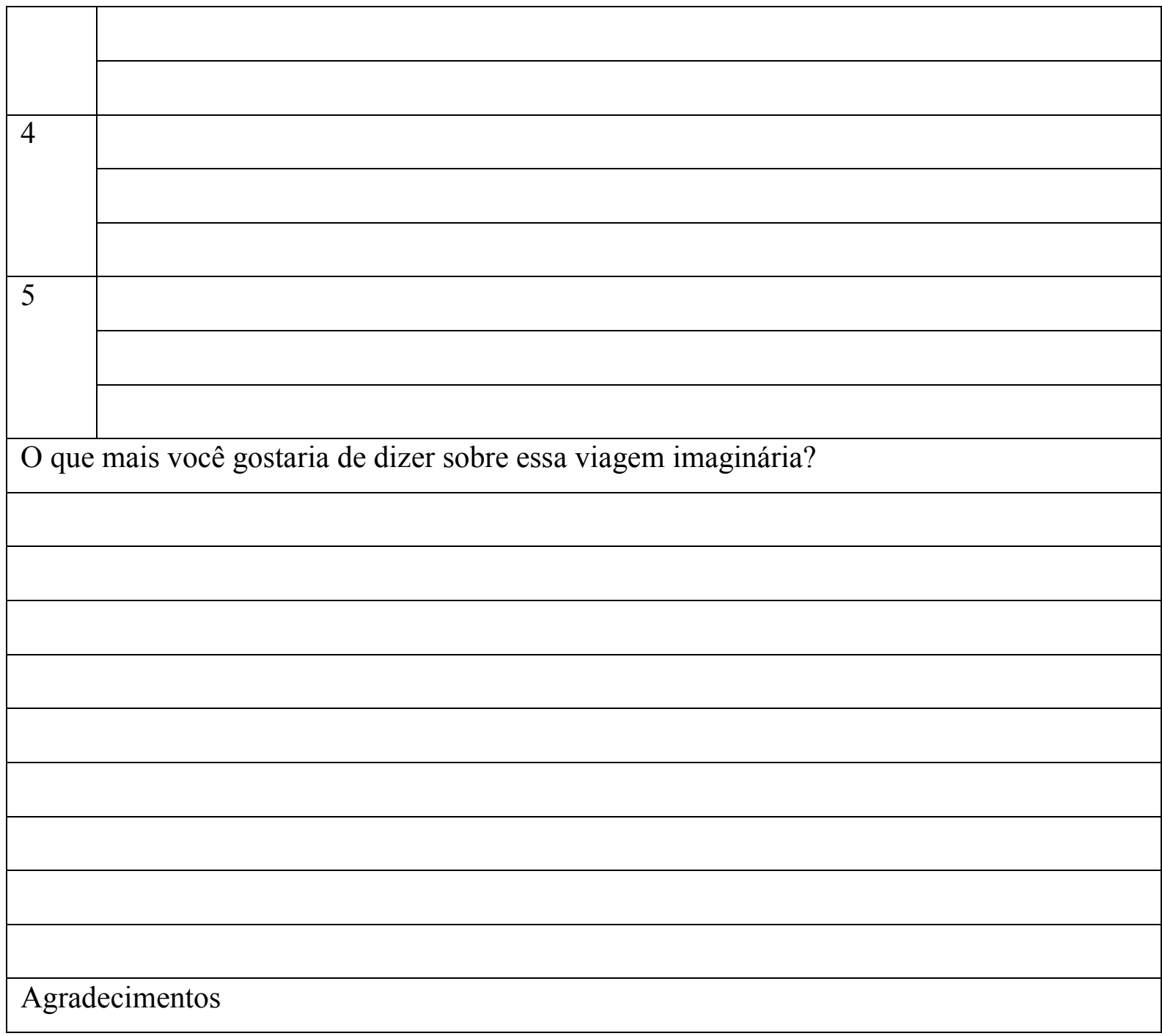




\section{APÊNDICE C}

\section{TERMO DE CONSENTIMENTO LIVRE E ESCLARECIDO}

Senhor (a) participante:

Sou aluno de pós-graduação em Turismo da Universidade de Brasília e estou convidando você a participar de uma pesquisa que tem por objetivo obter informações úteis para a elaboração de uma política pública de turismo para beneficiar jovens de baixa renda.

Gostaria de entrevistá-lo (a) de acordo com sua disponibilidade. Informo que a entrevista terá no máximo uma hora de duração. Caso concorde em colaborar com a gente preciso de sua autorização para que a entrevista seja gravada em áudio.

A sua colaboração é fundamental para o êxito desta pesquisa.

É importante ressaltar a garantia do sigilo de tudo o que for dito durante a entrevista. Somente o pesquisador terá acesso a esse material. Entretanto os resultados da pesquisa como um todo poderão ser divulgados em palestras, congressos, publicações e cursos acadêmicos, desde que mantido o sigilo dos nomes dos entrevistados.

A participação nas entrevistas é voluntária e as respostas livres de qualquer obrigação ou dever.

Brasília, de de 2014.

\section{Elvio Siquieroli Cavaton}

elviocavaton@uol.com.br-Fone: 8228-9999

Brasília, de de 2014

De acordo:

Nome:

Assinatura do(a) participante 